\title{
WestVirginiaUniversity
}

THE RESEARCH REPOSITORY @ WVU

Graduate Theses, Dissertations, and Problem Reports

2007

\section{Analysis of water monitoring data for longwall panels}

Joseph R. Zirkle

West Virginia University

Follow this and additional works at: https://researchrepository.wvu.edu/etd

\section{Recommended Citation}

Zirkle, Joseph R., "Analysis of water monitoring data for longwall panels" (2007). Graduate Theses, Dissertations, and Problem Reports. 4354.

https://researchrepository.wvu.edu/etd/4354

This Thesis is protected by copyright and/or related rights. It has been brought to you by the The Research Repository @ WVU with permission from the rights-holder(s). You are free to use this Thesis in any way that is permitted by the copyright and related rights legislation that applies to your use. For other uses you must obtain permission from the rights-holder(s) directly, unless additional rights are indicated by a Creative Commons license in the record and/ or on the work itself. This Thesis has been accepted for inclusion in WVU Graduate Theses, Dissertations, and Problem Reports collection by an authorized administrator of The Research Repository @ WVU. For more information, please contact researchrepository@mail.wvu.edu. 


\title{
Analysis of Water Monitoring Data for Longwall Panels
}

\author{
Joseph R. Zirkle
}

Thesis Submitted to the

College of Engineering \& Mineral Resources

at West Virginia University

in partial fulfillment of the requirements

for the degree of

Master of Science
In
Mining Engineering

Syd S. Peng, Ph.D., Chair

Yi Luo, Ph.D.

Felicia F. Peng, Ph.D.

Department of Mining Engineering

Morgantown, West Virginia

2007

Keywords: aquifer, hydrograph, hydrology, piezometer, subsidence Copyright 2007 Joseph R. Zirkle 


\title{
A bstract
}

\section{Analysis of Water Monitoring Data for Longwall Panels}

\author{
Joseph R. Zirkle
}

As the large coal reserves are depleted, the coal industry is forced to explore smaller coal seams with lower cover. The strict environmental regulations in today's coal industry will soon influence or prohibit mining the smaller, shallower coal reserves due to the land surface and subsurface subsidence affects from undermining. Therefore, an analysis of surface and subsurface affects has been conducted in to better understand the relationship between the subsidence mechanism and hydrological impact of subsidence in areas with low cover.

A field study near Waynesburg, Pennsylvania was undertaken from 1998 through 2004. The hydraulic pressure heads in the local aquifers were monitored and recorded by 30 piezometer wells in 8 locations over a 9 panel longwall district. The Laurel Run stream located directly above the longwall district was monitored by 16 stream flow stations. Precipitation data was considered during the analysis. 


\section{Acknow lagments}

I have many people I would like to acknowledge that helped to make this work possible. First, I would like to thank Foundation Coal for their contributions of funding for this project. Secondly, I would like to thank the members of the Pennsylvania Services Corporation for previously conducting the field work and collecting the data analyzed and presented in this work.

I would like to especially acknowledge my committee members Dr. Syd Peng, Dr. Yi Luo, and Dr. Felicia Peng for all their help and advice in writing this document. I would like to also thank all the fellow WVU Mining Engineering Graduate Students who have graciously give me ideas and direction in developing this project during project meetings. I would like to also thank the administrative staff of the Mining Department, Karen Centofanti and Jennet Cooley for all their help and reminders of when deadlines were approaching and assisting in getting things submitted on time.

Most importantly, I would like to thank my family and friends and especially my wife, Richelle, for all her patience, help, and support. 


\section{Table of Contents}

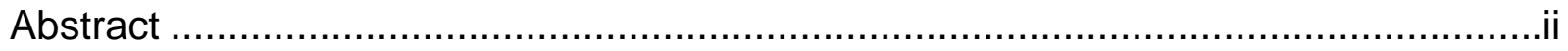

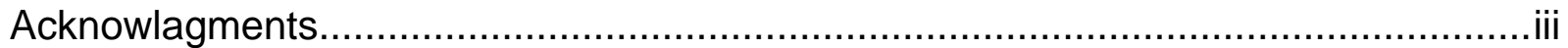

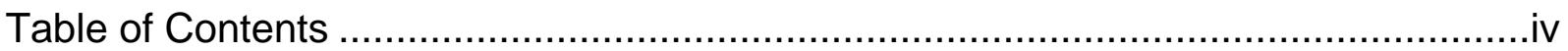

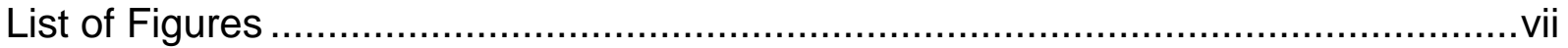

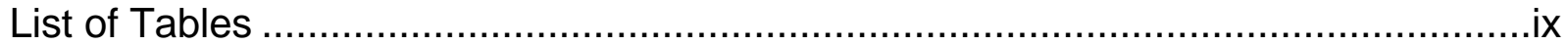

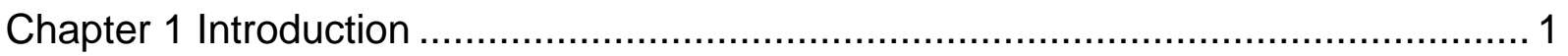

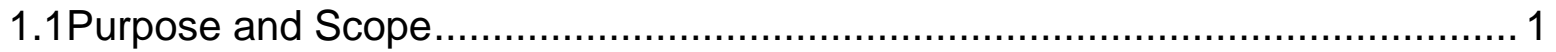

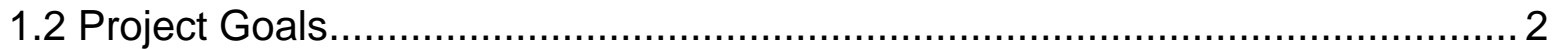

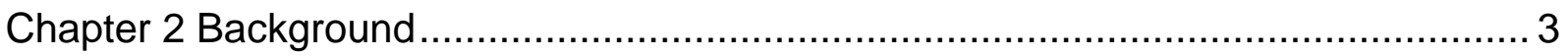

2.1 Aquifers and Aquitards - Definitions ....................................................... 3

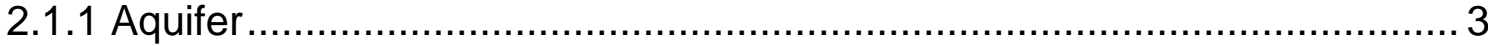

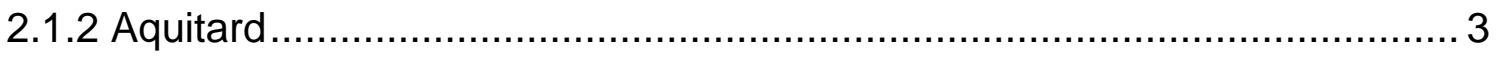

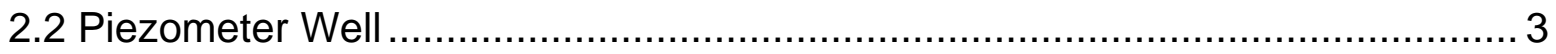

2.3 Overburden Movement and De-watering Effect due to Longwall Mining............ 5

2.4 Natural Groundwater Level Variability ..................................................... 6

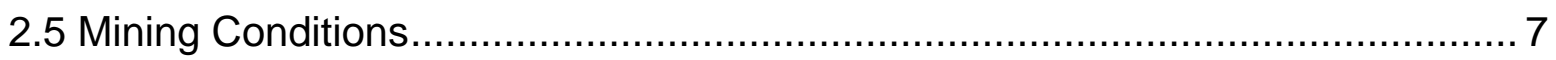

Chapter 3 Hydrological Monitoring and Data Collection of Stations Over Longwall

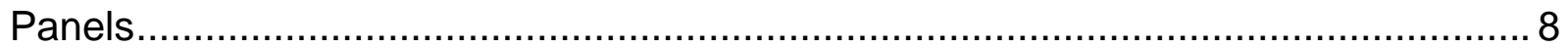

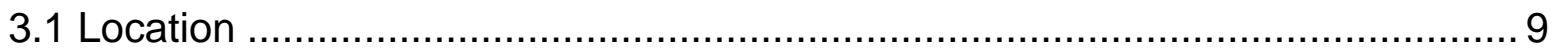

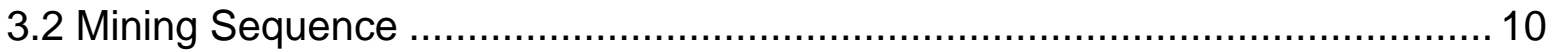

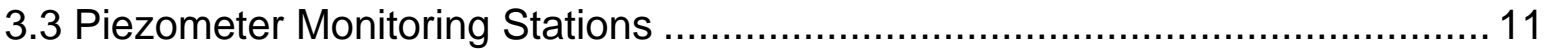

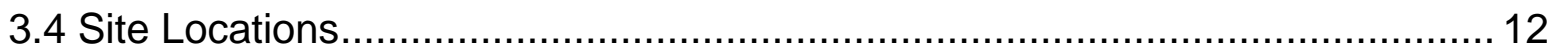

3.4.1 Site 1:

3.4.2 Site 2:

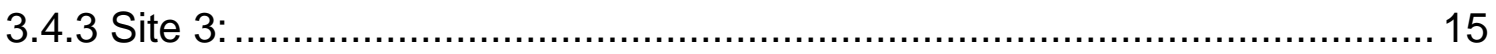

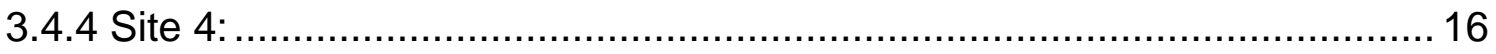

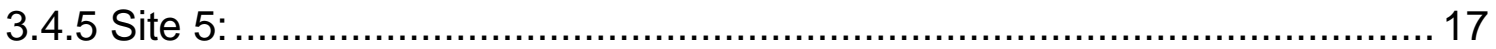

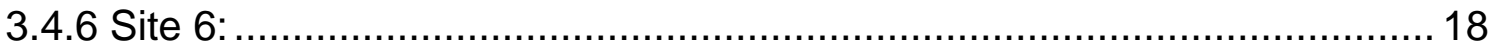

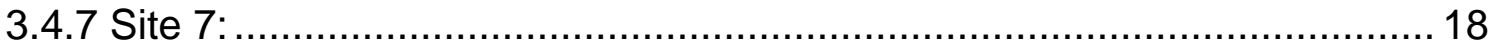




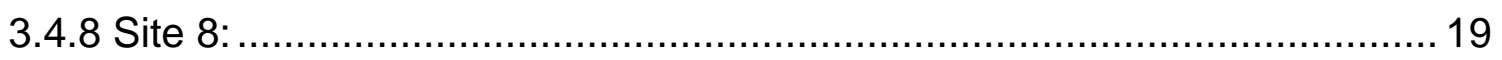

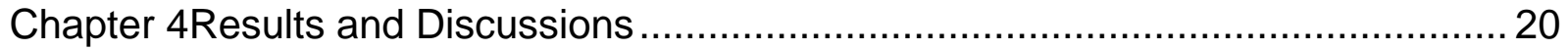

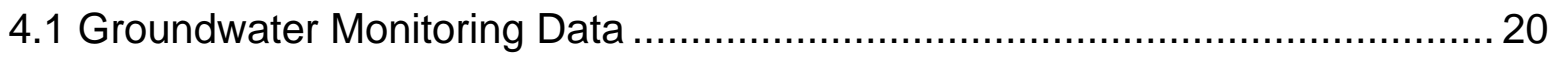

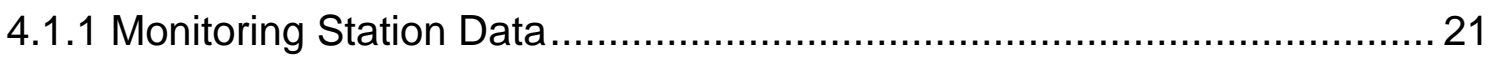

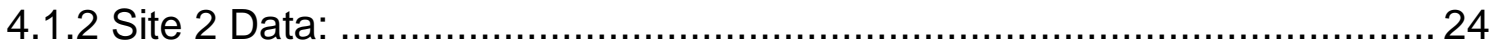

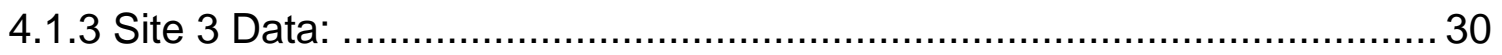

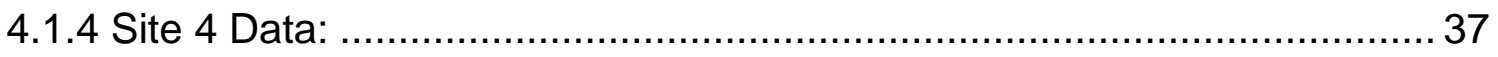

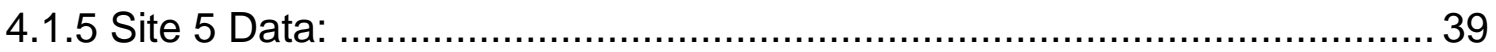

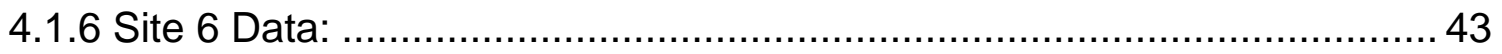

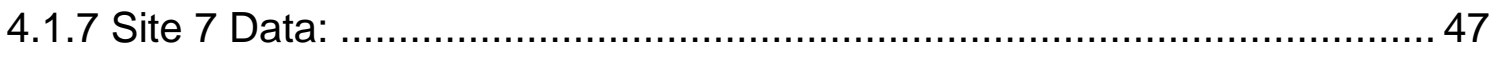

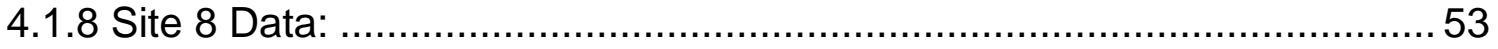

4.2 Longwall Mining Affect on Hydrographs of Water Wells............................... 59

4.2.1 Aquifer versus Aquitards - General .................................................. 59

4.2.1.1Aquifer Strata_Sewickley Sandstone ................................................. 59

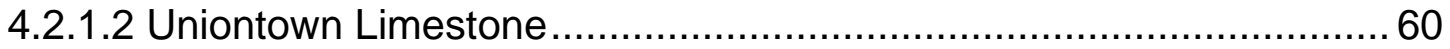

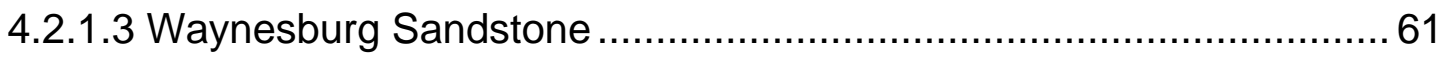

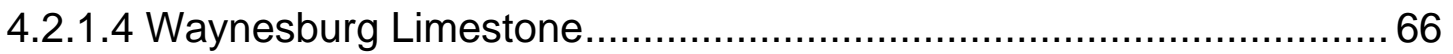

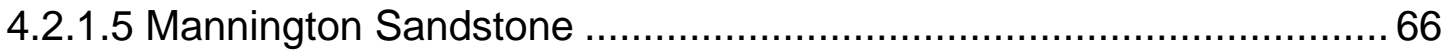

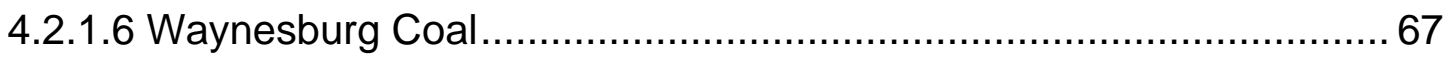

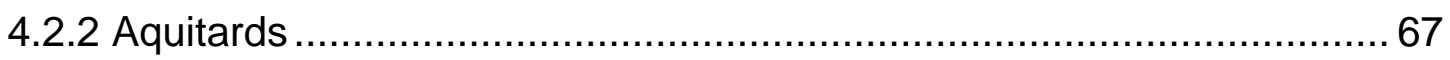

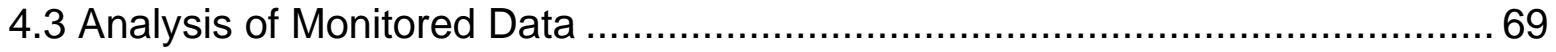

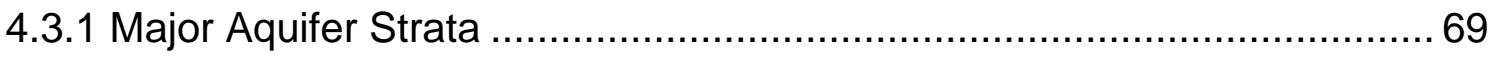

4.3.2 Aquitards -Clay Shale and Silty shale with Sandstone Streaks............... 71

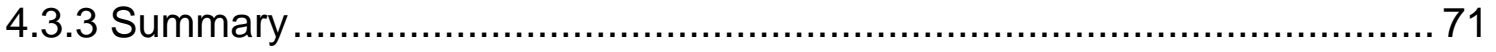

4.4 Precipitation and Stream flow Monitoring ................................................. 74

4.5 Effect of Longwall Mining on Surface Stream............................................ 74

4.5.1 Stream flow Analysis of Selected Surface Monitoring Stations ............... 74

4.5.1.1 Comparison of Stream Flow between Stations M7 and SW37 ......... 74

4.5.1.2 Comparison of Stream Flow between Stations SW37 and SW24 .... 75

4.5.1.3 Comparison of Stream flow Between Stations M5 and M4 and M4A 79

4.5.2 Mechanisms of De-watering due to Longwall Mining …......................... 82 


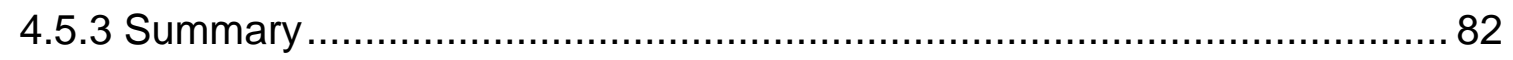

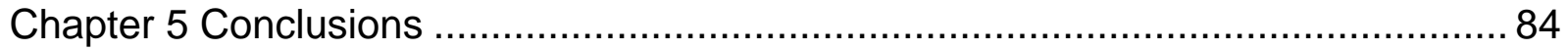

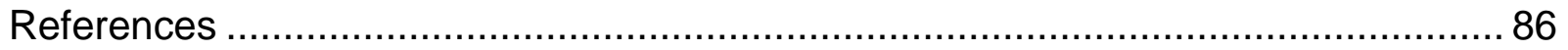

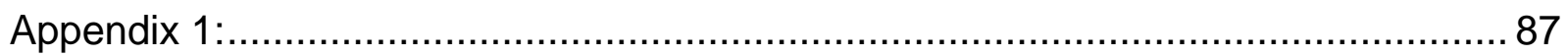

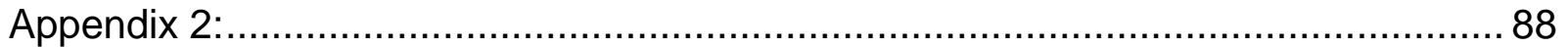

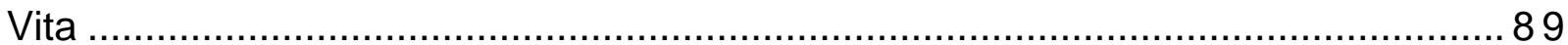




\section{List of Figures}

Figure 1 Piezometer Well Design Schematic ..................................................... 4

Figure 2 Overburden movement resulting from longwall mining ................................. 5

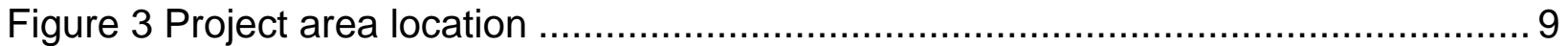

Figure 4 Mine map with surface topography and mining sequence .......................... 10

Figure 5 Site locations with overburden thickness contours and surface topography

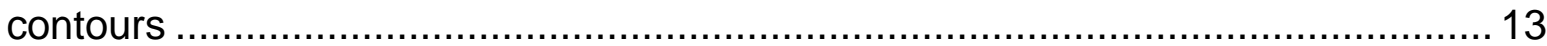

Figure 6 Site 1 location of PZ 31 and 32 north of the 1 North Panel .......................... 14

Figure 7 Site 2 location of PZ 1 through PZ 2 located in the 1 North panel.................. 15

Figure 8 Site 3 location of PZ 4 through PZ 8 located in the 4 North panel.................. 16

Figure 9 Site 4 location of PZ 26 through PZ 28 in the 5 North panel ......................... 16

Figure 10 Site 5 location of PZ 9S, 9D, 10, and 11 in the 6 North panel ..................... 17

Figure 11 Site 6 location of PZ 12, 13, and 25 in the 7 North panel .......................... 18

Figure 12 Site 7 location of PZ 14, 15, 16, 17, 18 and 19 in the 8 North panel ............ 19

Figure 13 Site 8 location of PZ 20, 21, 22, and 23 in the 9 North panel ...................... 19

Figure 14 Combined groundwater elevation over time for Site 1 including stream flow

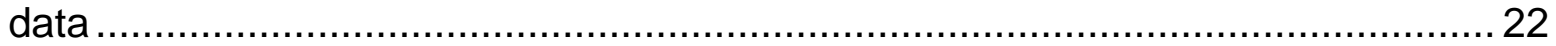

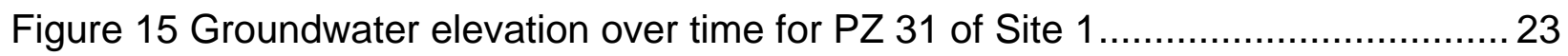

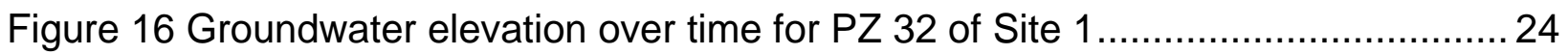

Figure 17 Combined groundwater elevation over time for Site 1 including stream flow

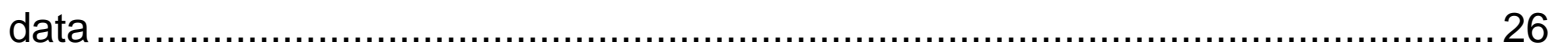

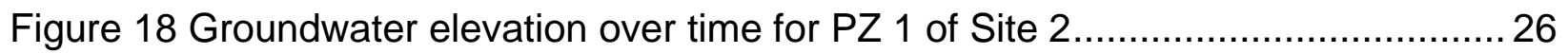

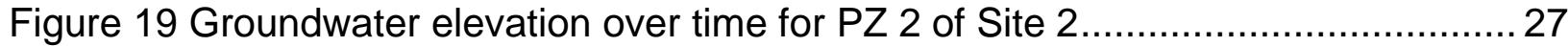

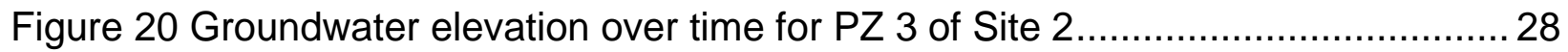

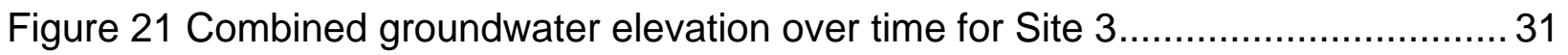

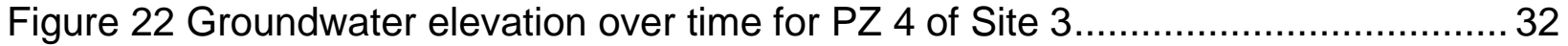

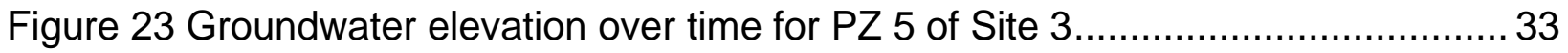

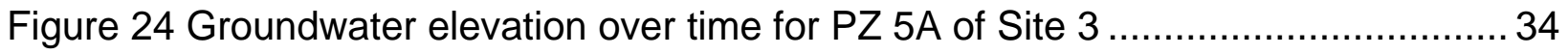

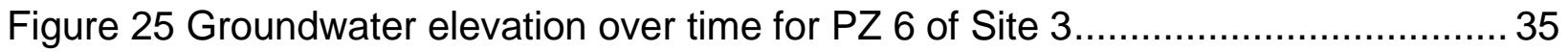

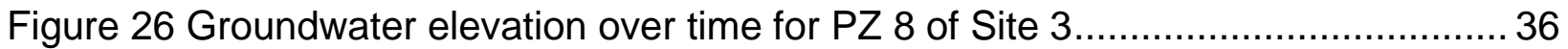




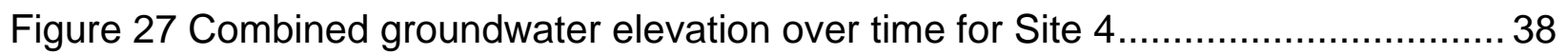

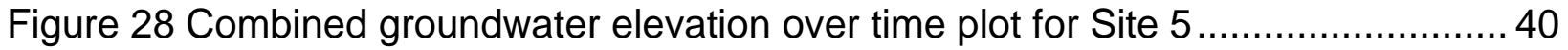

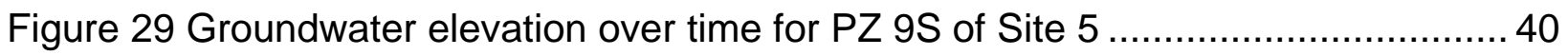

Figure 30 Groundwater elevation over time for PZ 9D of site 5................................ 41

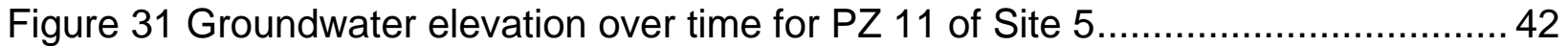

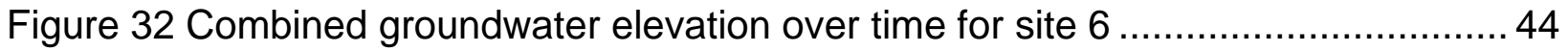

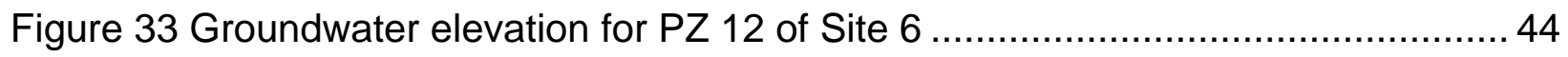

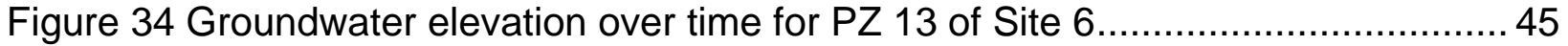

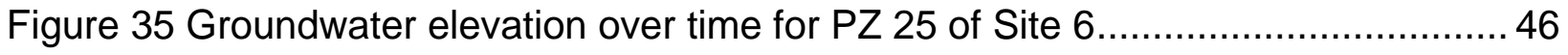

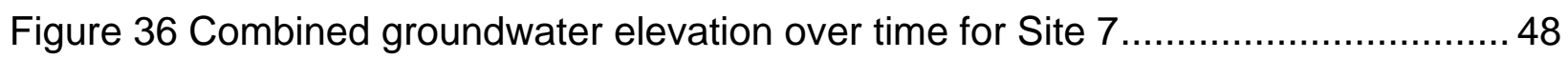

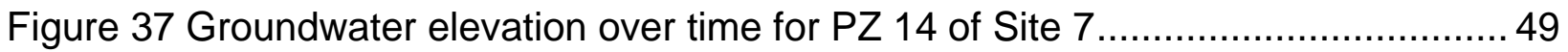

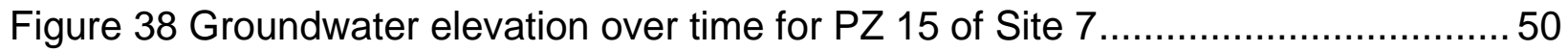

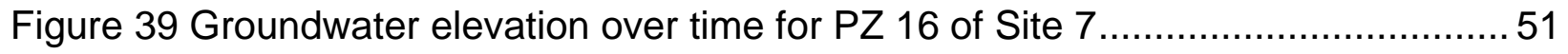

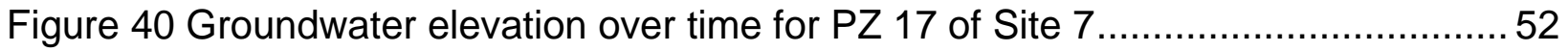

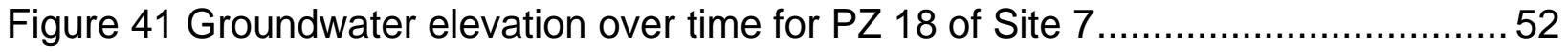

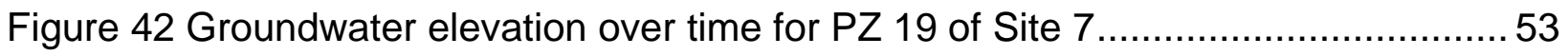

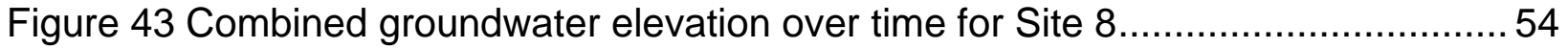

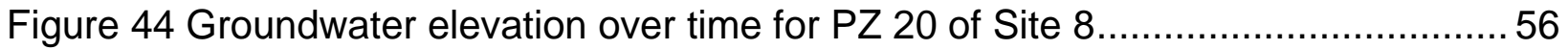

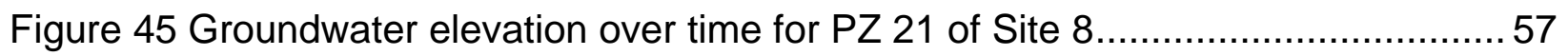

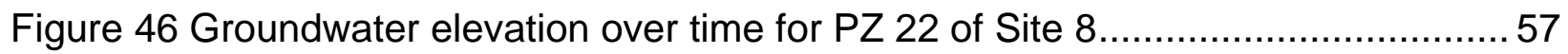

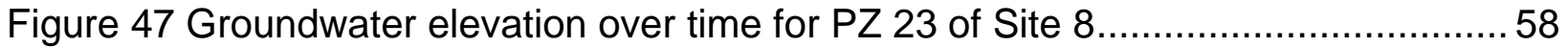

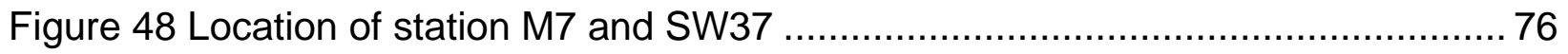

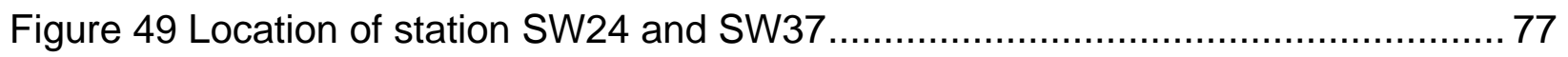

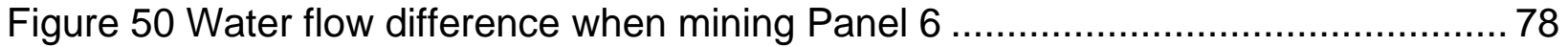

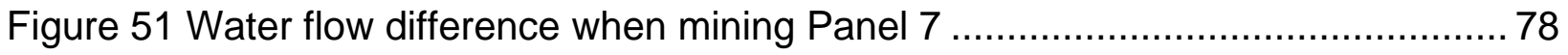

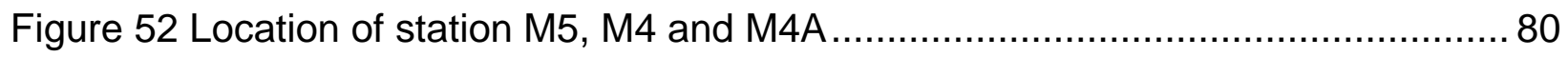

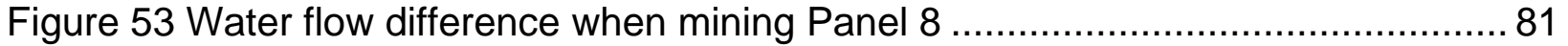

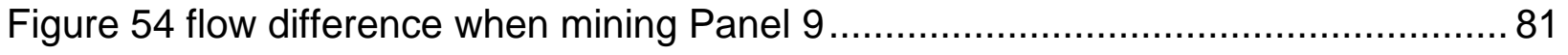




\section{List of Tables}

Table 1 Comparison of Flow Rates Between M7 and SW37 ..................................... 75

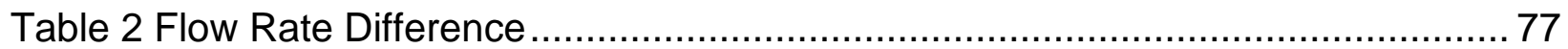

Table 3 Comparison of Flow Rate between Stations M5 and M4+M4A ...................... 80 


\section{Chapter1 Introduction}

Longwall mining is a method of complete extraction of large block of a coal seam which causes an instantaneous disturbance to all structures found in or on the strata above. In most cases, the strata above the coal seams with active mining have numerous aquifers and streams that are impacted by the subsidence event and, in some cases, are permanently affected. Pennsylvania's groundwater is a critical resource that contributes to the well-being of nearly fifty percent of the population who live in rural areas (DEP, 2001)

There has been many technological advances developed in the past two decades, all made possible by the advancement in computer technology, to predict, model, and understand mine subsidence. Traditionally in the past, there have been more emphases placed on understanding how subsidence affects structures on the surface. There are many computer simulation models available to accurately predict the location and intensity of subsidence affects for an area prior to mining. Currently, these models cannot asses the subsidence related affects that occur to the surface streams and aquifers.

Hydrologic data before and after mining was collected from a stream and the underling strata by a coal company in south western Pennsylvania, recording the changes to the stream and subsurface water system as the longwall panels were mined. The data set for these panels showcased the affects of the longwall mining methods, allowing a comparison between before and after extraction.

\subsection{Purpose and Scope}

Groundwater and stream data collected from piezometer wells and stream flow monitoring stations was analyzed and synchronized to the mining advance rates in order to better understand how the groundwater system and streams were affected by subsidence. Data analysis took place to see how the active longwall section motions affected the project area hydrology. The collected data contains both prior and post mining data. The range of data, when shown in a hydrograph form, showed how the aquifers and streams changed as mining advanced through the project area. The 
distance from surface and subsurface features to the active longwall panel was analyzed. Geological parameters, such as the surface or aquifer location in the stratum relative to the coal seam, were studied to identify the range of parameters resulted in a permanent change (aquifer/stream failed to recover during the collection period). The results of this work can be used to develop better mining related hydrological monitoring, modeling, and evaluation methods for aquifers and streams subject to future mine planning and development. The results of this work can also be used to develop a computerized model capable to predict relative subsidence related hydrology affects for a proposed mining area.

\subsection{Project Goals}

The goals of this project were to determine how longwall mine subsidence affects the groundwater system and streams for the project area. The data for the project area was analyzed and summarized to determine which major aquifers are permanently affected by longwall subsidence and which aquifers are only temporarily affected. The Laurel Run stream was also analyzed to determine if it was permanently affected by mine subsidence. Precipitation data was gathered by a near by weather station and used to show how the weather affected the results presented in the hydrographs throughout the project area. 


\section{Chapter 2 Background}

\subsection{Aquifers and Aquitards - Definitions}

\subsubsection{Aquifer}

An aquifer is defined as a formation that contains sufficient saturated permeable material to yield significant quantities of water to wells or springs (Mays 2005). The aquifer porosity is defined as the portion of a rock that is not occupied by a solid mineral, namely voids (Mays, 2005). The porosity of any given aquifer can very greatly if the formation contains many natural factures, cracks, joints, and bed separations, all of which were formed by the geologic process (Mays, 2005).

\subsubsection{Aquitard}

An aquitard is a saturated but poorly permeable stratum the slows groundwater movement and does not yield water to wells (Mays 2005).

\subsection{Piezometer Well}

A piezometer well or groundwater monitoring well is a water well that is cased from the surface to the strata to be monitored. Just directly above the strata to be monitored, the well is grouted or sealed to prevent any water from other strata from entering the well casing. The bottom of the casing is slotted and is surrounded by a sand filter pack. Figure 1 shows the design of the piezometer wells for this project. All wells to be discussed in this report were installed with this design and only differ in depth because each well monitored a different strata or stratum. 


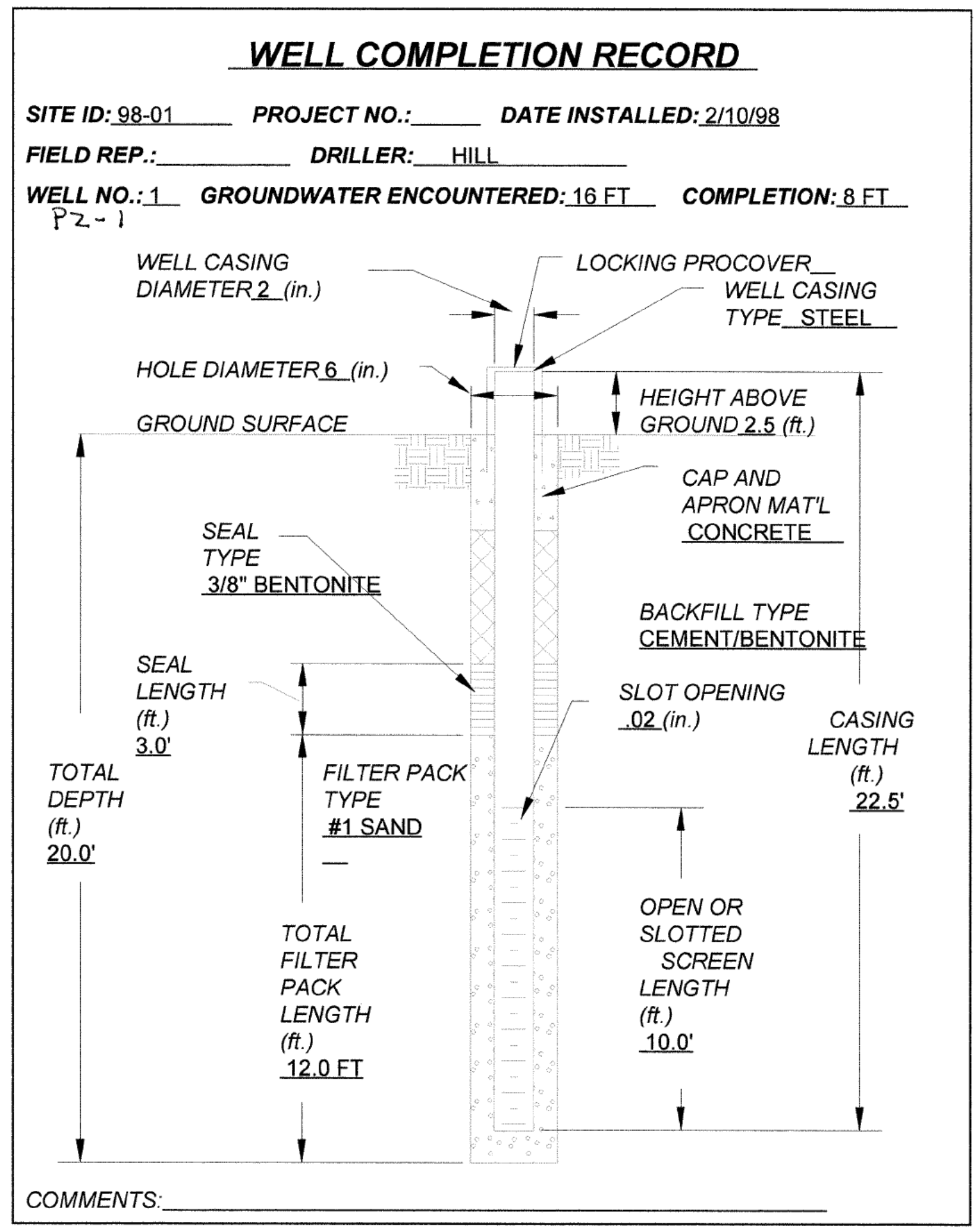

Figure 1 Piezometer Well Design Schematic 


\subsection{Overburden Movement and De-watering Effect due to Longwall Mining}

When a longwall panel is excavated, the overburden strata are disturbed in order of severity from the immediate roof toward the surface. Figure 2 (Peng and Chiang, 1984) shows the four zones in the overburden strata in response to the longwall mining below. The caved zone, which is the immediate roof before it caves, ranges in thickness from two to eight times the mining height (Peng, 1986). In the caved zone, the stratum falls on the mine floor and, is broken into irregular but platy shapes of various sizes and the rock volume in its broken state is considerably larger than that of the original intact strata (Peng, 1986).

Located directly above the caved zone is the fractured zone. In this zone, the strata are broken into blocks by vertical and/or sub-vertical fractures and horizontal bed separation cracks (Peng, 1986). The adjacent blocks in each broken stratum remain in contact either fully or partially across the vertical or sub-vertical fractures. Thus, a horizontal force is transmitted through and remains in the strata during deformation. With this horizontal force, the individual blocks in these broken strata cannot move freely without affecting the movements of the adjacent blocks (Peng, 1986). The thickness of the fractured zone ranges from 28 to 52 times the mining height (or its upper limit is 30 to 60 times the mining height above the roofline) (Peng, 1986). The combined thickness of the caved and fractured zones ranges from 30 to 60 times the mining height (Peng, 1986).

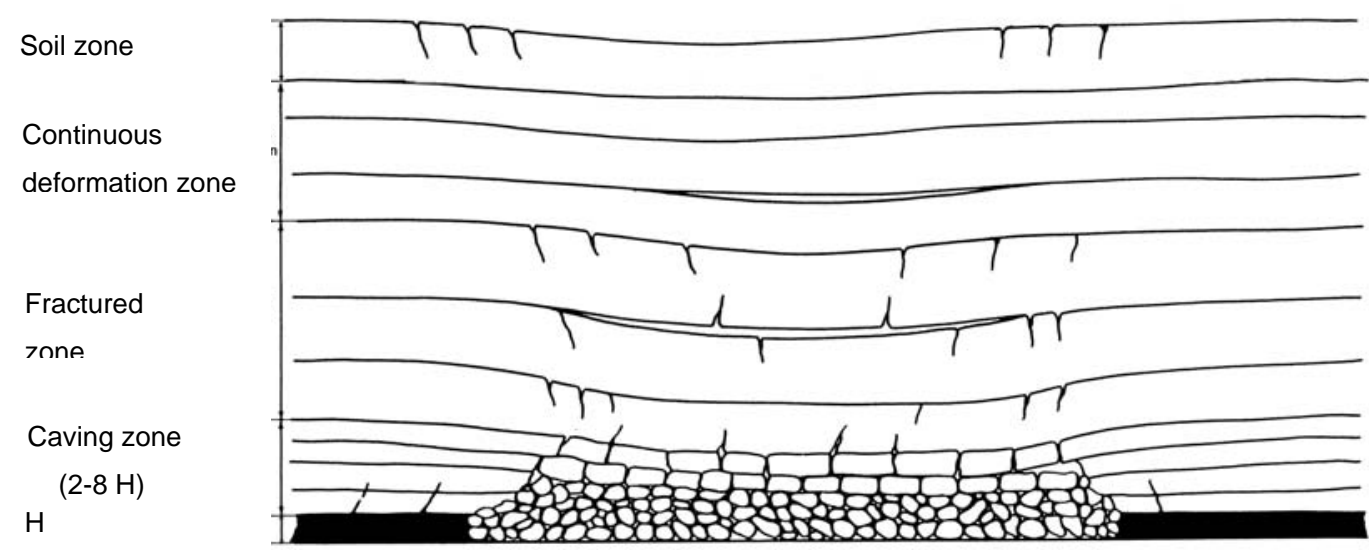

Figure 2 Overburden movement resulting from longwall mining 
Between the fractured zone and the surface is the continuous deformation zone. In this zone, the strata gently deforms without causing any major cracks that extend through the thickness of the strata, as in the fractured zone (Peng, 1986). The stratum in this zone behaves essentially like a continuous or intact medium (Peng, 1986).

On the surface, there is a soil zone of varying depth associated with the geologic location. In this zone, cracks are opened and closed as the longwall face comes and goes. In general, cracks on and near the panel edges tend to remain open permanently, whereas those in and around the center of the panel will close back up when the longwall face has passed by (Peng, 1986). Cracks vary from less than one to 3-4 $\mathrm{ft}$ (0.3 to $0.91-1.22 \mathrm{~m})$ wide and from less than $1 \mathrm{ft}(0.3 \mathrm{~m})$ deep to as deep as the soil zone

If surface water wells reach or aquifers are located in the caved and fractured zones, well water or groundwater in the aquifers will be lost permanently. On the other hand, if they are located in the continuous deformation zone, longwall mining should not affect well water or groundwater. And, if it does, it will be temporary. In the soil zone, as mining progresses, cracks open and close, and water levels will decrease and return. However, cracks of various depths parallel to the panel edges are expected to remain permanently and if surface wells are located in this region, water is likely to disappear permanently.

\subsection{Natural Groundwater Level Variability}

Groundwater systems fluctuate naturally due to changing seasonal precipitation. Shallow aquifers that contain a larger area for available recharge during the recharge events while the deeper strata must be recharged by the strata above and is limited based on the porosity of the aquifer or aquitard found above (Becher, 1999). This variation based on weather patterns alone can influence the outcome of groundwater elevation shown on hydrographs. These weather related groundwater fluctuations make it necessary to account for the weather related affects when analyzing the data gathered from the stream and the piezometer wells. 


\subsection{Mining Conditions}

The mining conditions noted and recording when the panel is developed serves as a road map of what the longwall will face when retreat mining the solid coal. Thinks in terms of the larger scale geology and lithology, the mining conditions or geologic conditions seen immediately above or below the coal seam often times gives the operator an idea what kind of geologic features extend beyond the immediate roof and floor, such as faults, clay veins, sandstone channels, ect. (Peng, 1986).

Mining conditions for this longwall district were variable depending on the location of the active mining sections. This particular coal mine extracted the Pittsburgh Coal Main bench which ranged from 5.5 feet to 7.0 feet thick. The operating mining height for the longwall system was nearly 7 feet, where the main bench coal, draw slate, and some rider coal were removed.

The overburden thickness between the coal seam and the surface is the most crucial geologic feature, sometimes less than 400 feet when approaching the stream, because roof control problems are commonly found when undermining a valley. Hazard maps have shown that longwall gateroad entries directly below the stream required cable bolts and cable trusses in addition to the traditional roof control method. Longwall retreat mining in the valley bottom areas often is difficult because of the common occurrence of valley faults and fractures that slow the longwall advance and spark undesirable roof control problems (Peng, 1986) 


\section{Chapter 3 Hydrological Monitoring and Data collection of Stations over Longwall Panels}

Longwall mining has been conducted under a stream with shallow cover close to 400 feet. Large amounts of groundwater and stream flow data have been collected for this area. The data collection process started in 1998, nearly 2 years before longwall mining began, and continued through 2004. Mining was completed near the end of 2002.

This work will cover the hydrologic monitoring program, description of each monitoring site conditions and geology, and the collected data in detail. The data shows that some aquifers and sections of the stream were disturbed, while others were not. If disturbed, the capacity and cause of this disruption is highly variable depending on the geologic conditions and thickness of the interburden between the coal seam, aquifer, and the surface. The data also shows the flow in the stream recovers nearly two years after mining in these panels was completed. 


\subsection{Location}

A particular coal mine is operating a longwall mine in south western Pennsylvania. The area of interest for this report is a portion of a watershed located nearly 1.5 miles south of Waynesburg, Pennsylvania. The stream of interest flows from south to north (See Figure 3).

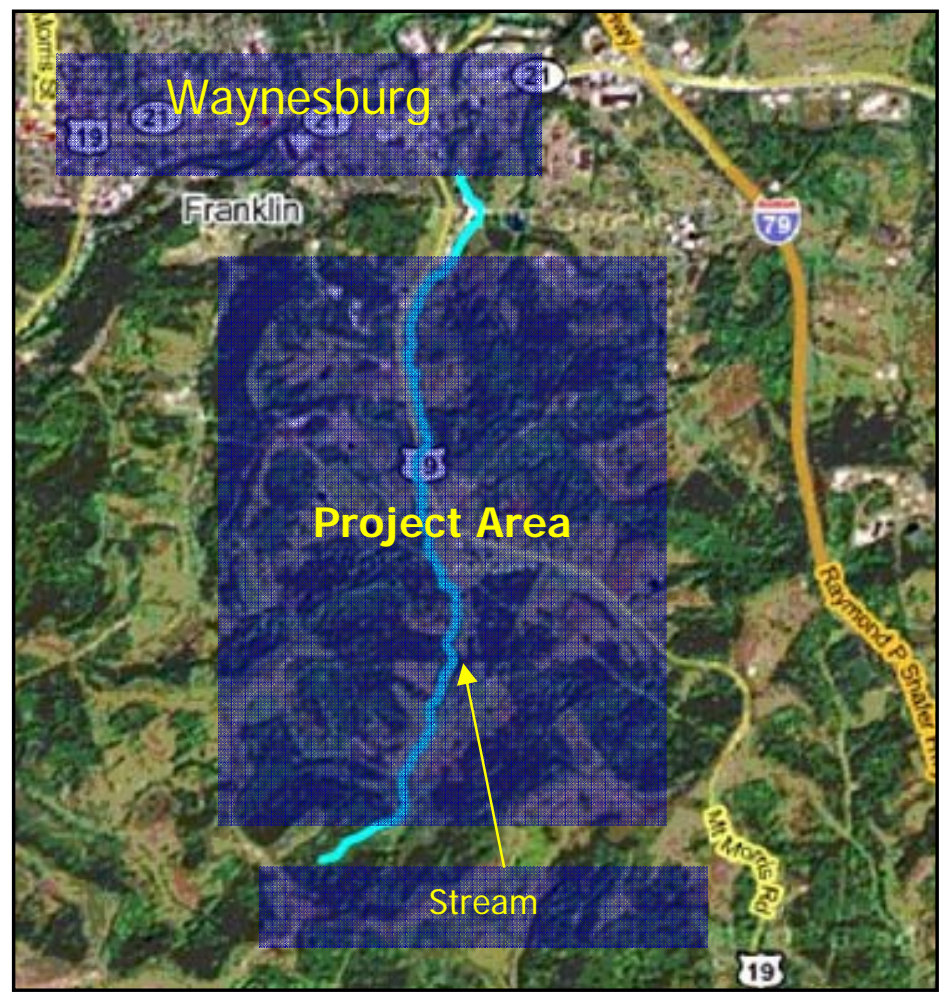

Figure 3 Project area location

This mine is operating in the Pittsburgh \#8 coal seam with a mining height of 7 feet. The rib-to-rib widths of the longwall panels are 1,000 feet. Figure 4 shows the mine plan and surface topography. The stream bisects the longwall panels perpendicularly. The stars in Figure 4 indicate the location of a group of groundwater monitoring wells. Triangles mark locations of surface water monitoring stations along the stream and tributaries within the watershed. 


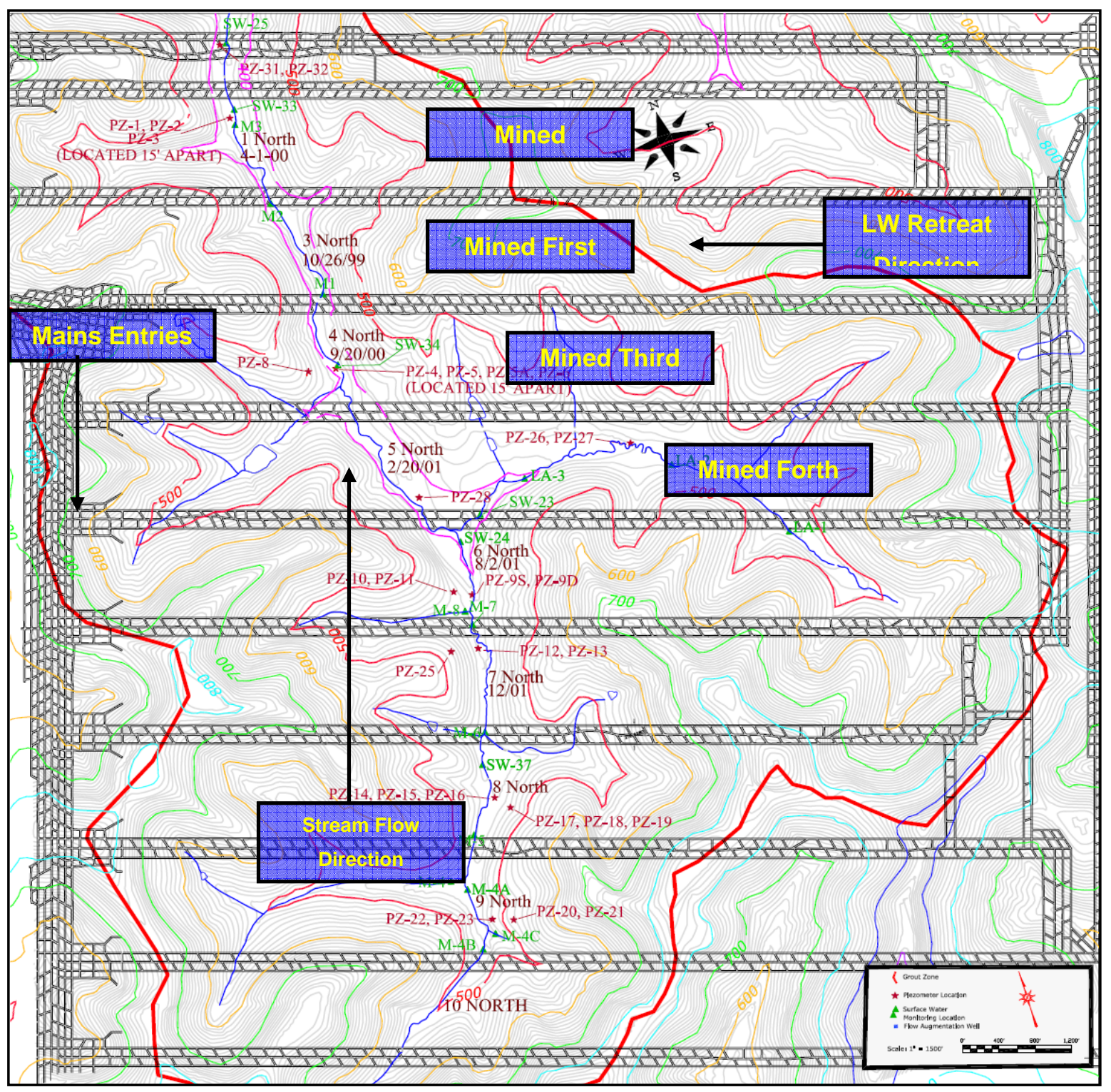

Figure 4 Mine map with surface topography and mining sequence

\subsection{Mining Sequence}

The longwall panels were retreat-mined from east to west. The Main entries were driven southward and longwall gate road entries branched off to the east from the main entries. The first panel of the 9 panel district was the 1 North panel, numbered 1 through 10 while skipping 2 North. The mining order of these panels was as follows. The 3 North panel was mined first. After the 3 North panel was depleted, the longwall moved northward to extract the 1 North panel. Once the 1 North panel was completed, 
the 4 North panel was mined. The panels south of the 4 North panel were mined in numerical order until the end of the district.

\subsection{Piezometer Monitoring Stations}

The data presented in this work was collected by a mining company and consisted of an extensive pre-mining and post-mining hydrological monitoring database for the stream of interest. The monitoring database includes 20 stream flow monitoring stations and 33 groundwater monitoring stations. The groundwater monitoring stations measured the water pressure head of the selected stratum. The water pressure head will be discussed in terms of water elevation (or change in elevation) throughout the remainder of the report. The stream flow monitoring stations are located along the Laurel Run stream and tributaries. The stream monitoring station locations are denoted by the triangles in Figure 4 and Figure 5 .

There will be more emphasis made to evaluate the groundwater changes or effects due to undermining the monitoring wells. Therefore, there will be limited discussion on the stream monitoring data within this report. Some of the following figures will show time periods when the stream was flowing or dry and this information was collected from the nearest stream flow monitoring station. Stream flow and precipitation data analysis, namely groundwater recharge, will be discussed later in Chapter 4.

All data will be discussed starting from the northern portion of the project area. This order of presentation will show the data as mining progressed, which also was progressing upstream along the valley.

This report will discuss 30 of the 33 piezometer wells throughout the Laurel Run watershed. Three wells were discarded because of missing data sets or insufficient data for this project. The 30 groundwater wells will be divided into groups or sites, each containing 2-6 groundwater wells. All wells located in the same site are located within the same longwall panel. The following section will introduce the site locations. After introducing the site locations, the piezometer well data will be discussed in detail for each site. Site specific and overall conclusions will conclude the work. 


\subsection{Site Locations}

First, the surface features (stream and well locations) relative to the coal seam, longwall panels, elevation, and well depth will be discussed. These sites are identified as Site 1 , Site 2 , Site 3 following through to Site 8 and are located in order progressing southward throughout the project area (see Figure 5). Site 1 has the least overburden thickness (372 feet) and Site 8 has the most overburden thickness (490 feet).

Figures throughout this section will be closer views of Figure 5 . This series of illustrations will contain the longwall panel name and approximate date of the longwall mining system undermining the Laurel Run stream. The red stars represent the location of a single or group of piezometer wells. The triangles represent the location of stream monitoring or stream flow monitoring stations. The colored and labeled contour lines are the Pittsburgh coal overburden thickness and the light gray contours are the surface topography. Refer to Appendix 1: for a detailed tabular summary of all piezometer wells for the project area. 


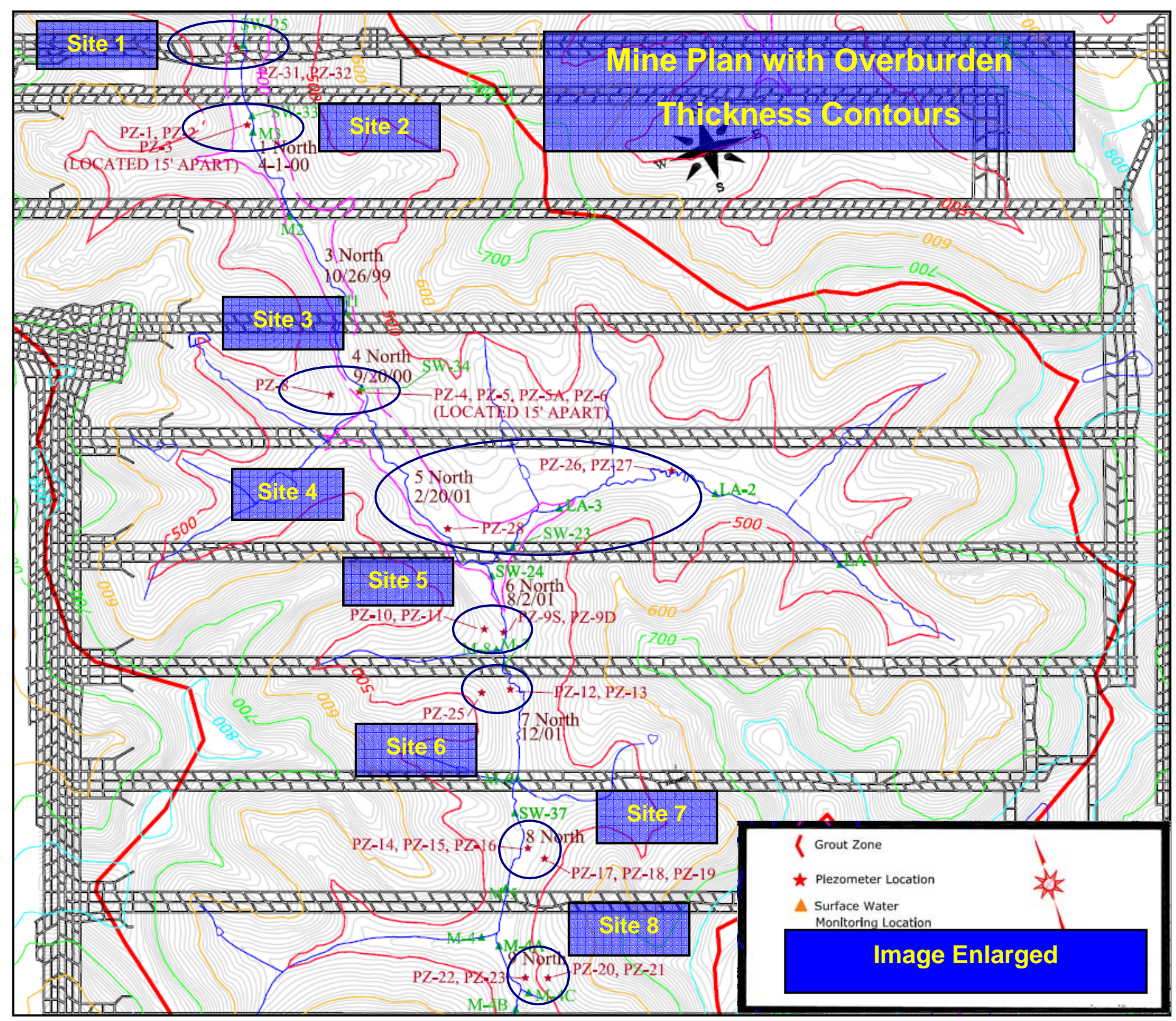

Figure 5 Site locations with overburden thickness contours and surface topography contours 


\subsubsection{Site 1:}

Site 1 was located north of the 1 North panel, located approximately 600 feet from the tailgate entry of the 1 North panel. The 1 North panel is located in the northern most part of the longwall district (see Figure 5 for an overview of the site locations). In this area, the overburden thickness was 370 feet.

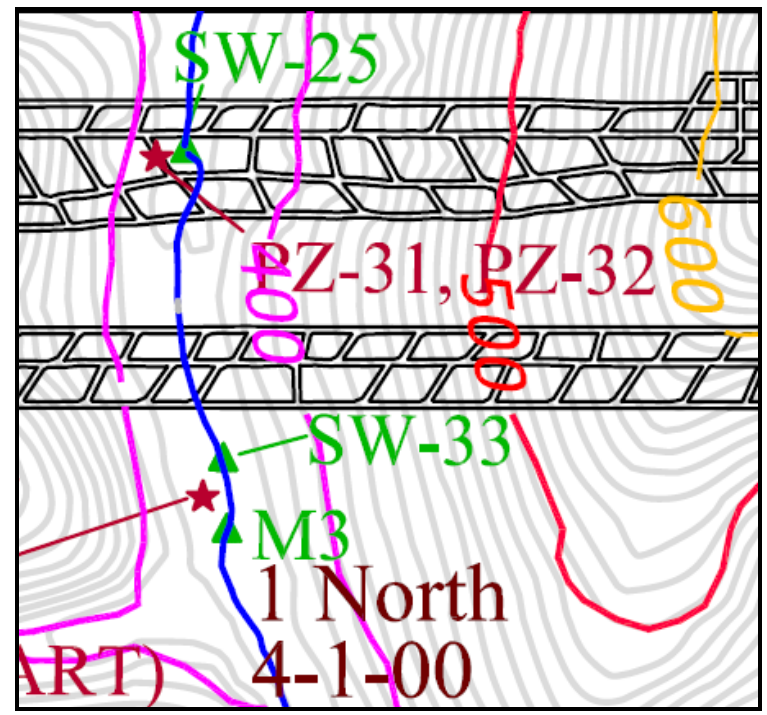

Figure 6 Site 1 location of PZ 31 and 32 north of the 1 North Panel

Site 1 contained two piezometer wells, PZ 31 and PZ 32 (shown in Figure 6) and are denoted by the star located 600 feet north of the 1 North panel. These wells are nearly 15 feet apart. The depths of PZ 31 and PZ 32 in order were 20 feet and 65 feet, respectively. These two wells were located above old mine workings and were not undermined using longwall methods.

\subsubsection{Site 2:}

Site 2 was located in panel 1 North and contained three piezometer wells (See Figure 7). The star located 250 feet south of the 1-North panel tailgate is marking the location of PZ 1, 2, and 3 groundwater monitoring wells. These wells were located 15 feet apart in the valley and are close to the stream. The depths of the PZ 1, 2, and 3 wells in order are 20 feet, 140 feet, and 270 feet deep, respectively. The overburden thickness for this site was nearly 378 feet. 


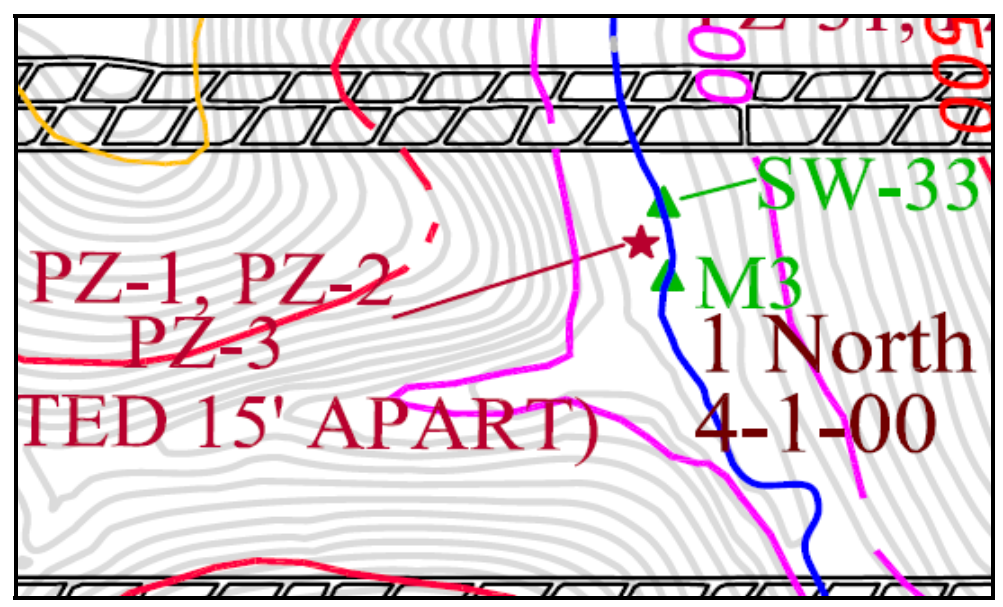

Figure 7 Site 2 location of PZ 1 through PZ 2 located in the 1 North panel

\subsubsection{Site 3:}

Site 3 is located in the 4 North panel which is the third panel of the longwall district (See Figure 8). This site contains five piezometer wells, four of which are located near the stream and one located on the hillside. Also, these five wells are located in the center of the longwall panel width. The overburden thickness for this site ranges from 370 feet to 408 feet between the valley and hillside wells. Piezometers 4 , 5, 5A, and 6 are located 15 feet apart and approximately 30 feet away from the stream. Piezometer 8 is located approximately 200 feet away from the stream located on a gentle slope and drilled after the longwall panel passed through the area. The depths of the Piezometers 4, 5, 5A, 6, and 8 wells in order are 22.5 feet, 142.5 feet, 60 feet, 269.5 feet, and 70 feet, respectively. Please note PZ 5A is a replacement well installed after the longwall face passed this location to replace crushed or shifted wells. Piezometer 5 became obstructed after undermining and was later replaced by piezometer 5A. 


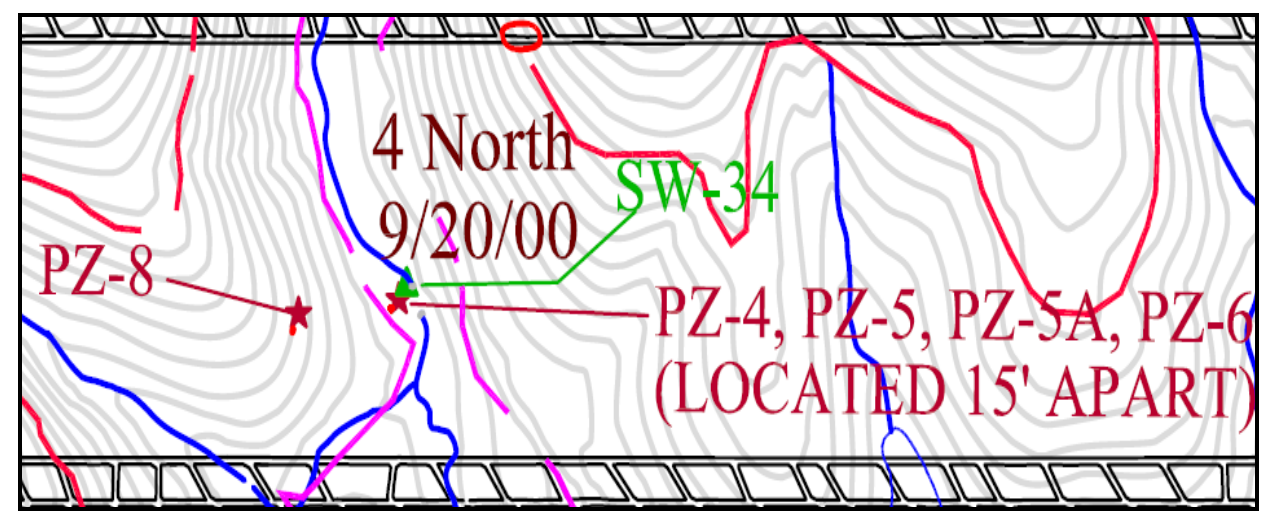

Figure 8 Site 3 location of PZ 4 through PZ 8 located in the 4 North panel

\subsubsection{Site 4:}

Site 4 is located in the 5 North panel (See Figure 9). This site contains three piezometer wells, all are located near the stream, but can be found in two different locations. PZ 26 and 27 are located near an un-named tributary of Laurel Run and 233 feet from the 5 North panel tailgate. PZ 28 is located near Laurel Run stream and is 139 feet from the 5 North panel headgate. The wells' depths in order are 40 feet, 80 feet, and 100 feet for $P Z$ 26, 27, and 28. The overburden thickness ranges from 375 feet for PZ 26 and 27 to 404 feet for PZ 28.

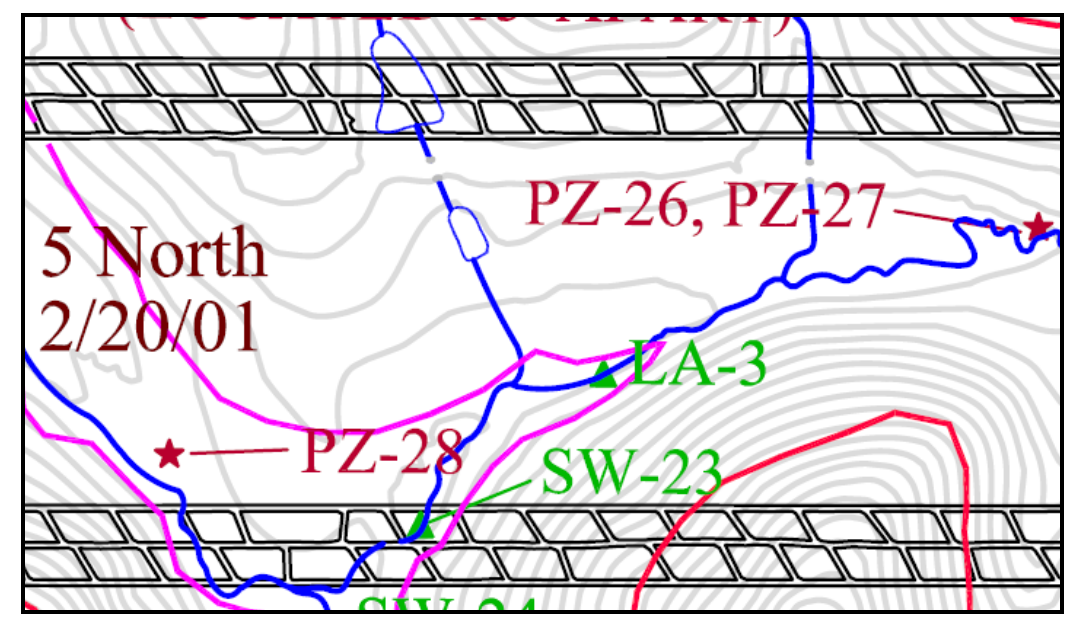

Figure 9 Site 4 location of PZ 26 through PZ 28 in the 5 North panel 


\subsubsection{Site 5:}

Site 5 is located in the 6 North panel and contains four piezometer wells, two located in the valley near the stream and two on the hillside slope (See Figure 10). PZ 9S and 9D are located near Laurel Run and are 253 feet from the 6 North panel headgate. PZ 10 and 11 are the hillside wells and are located 288 feet from the 6 North headgate. The horizontal distance between the valley and hillside wells is approximately 150 feet. The depths of these wells in order are 19.58 feet, 58.75 feet, 19.79 feet, and 76.67 feet for PZ 9S, 9D, 10, and 11, respectively. The overburden thickness ranges from 386 feet for PZ 9S and 9D and 424 feet to PZ 10 and 11.

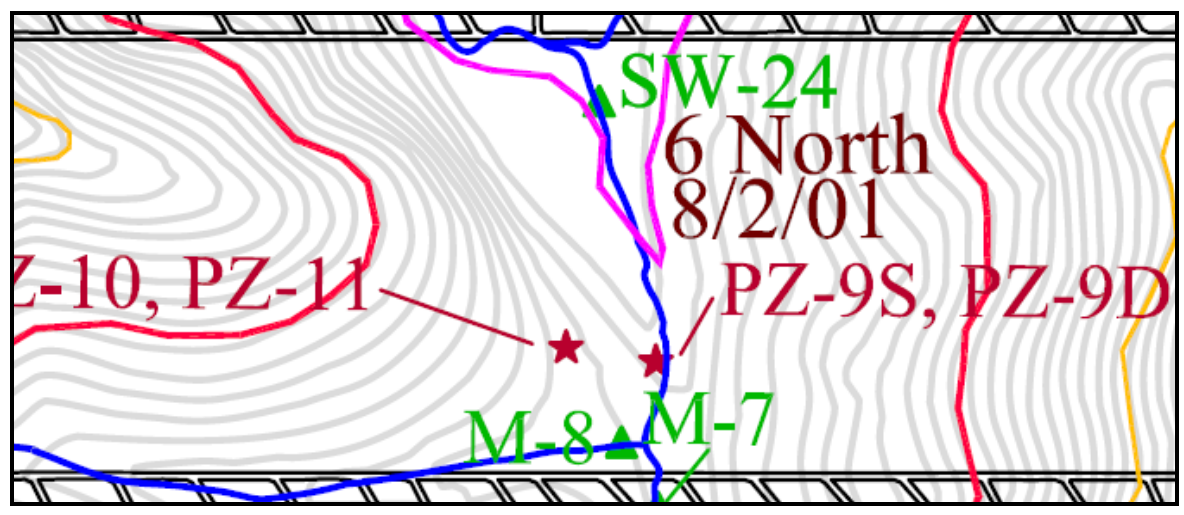

Figure 10 Site 5 location of PZ 9S, 9D, 10, and 11 in the 6 North panel 


\subsubsection{Site 6:}

Site 6 is located in the 7 North panel and contains four piezometer wells, two located in the valley near the stream and one near the hilltop (see Figure 11). PZ 12 and 13 are located near Laurel Run and are 128 feet from the 6 North panel tailgate. PZ 25 is on the hilltop and is located 167 feet from the 6 North tailgate. There is nearly 200 feet between the hilltop and valley wells for this location. The depths of these wells in order are 22.5 feet, 68.67 feet, and 111 feet for PZ 12, 13, and 25, respectively. The overburden thickness ranges from 403 feet for PZ 12 and 13 to 495 feet for PZ 25.

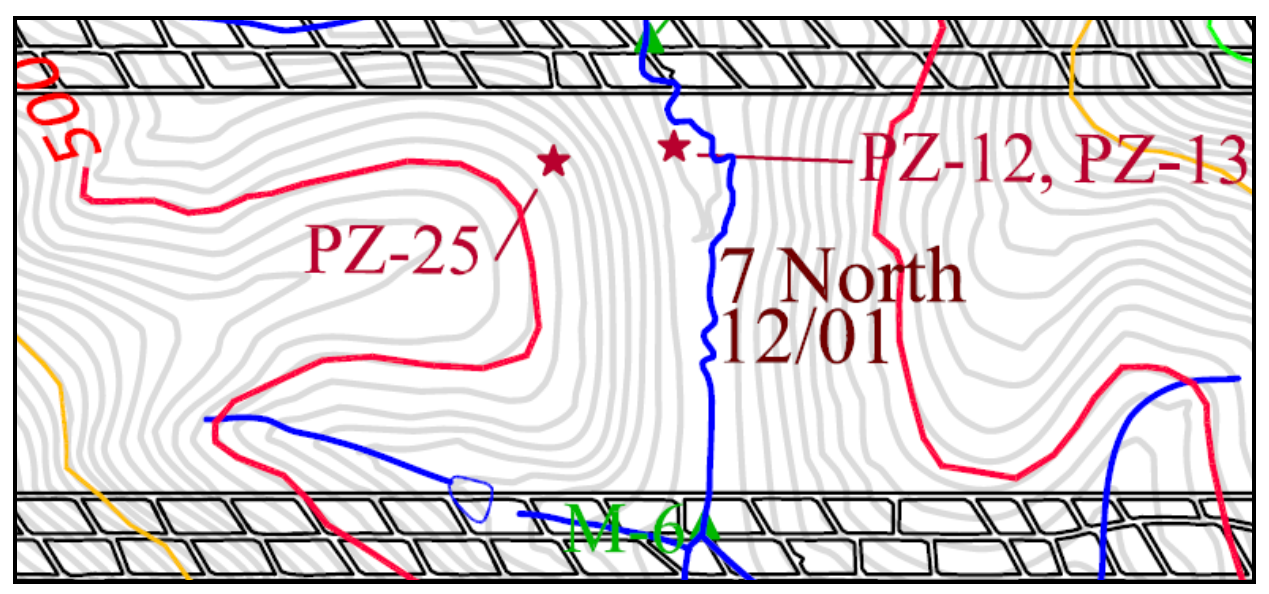

Figure 11 Site 6 location of PZ 12, 13, and 25 in the 7 North panel

\subsubsection{Site 7:}

Site 7 is located in the 8 North panel and contains six piezometer wells, three located in the valley near the stream and three on the hillside slope (see Figure 12). PZ 14, 15, and 16 are located near Laurel Run and are 328 feet from the 6 North panel headgate. PZ 17, 18, and 19 are located on the hillside slope and are 230 feet from the 6 North panel headgate. There is nearly 130 feet between the hilltop and valley wells for this location. The depths of these wells in order are 20 feet, 33 feet, 60 feet, 22.33 feet, 30.75 feet, and 69 feet for PZ 14, 15, 16, 17, 18, and 19, respectively. The overburden thickness ranges from 417 feet for PZ 14, 15, and 16 to 487 feet for PZ 17, 18 , and 19. 


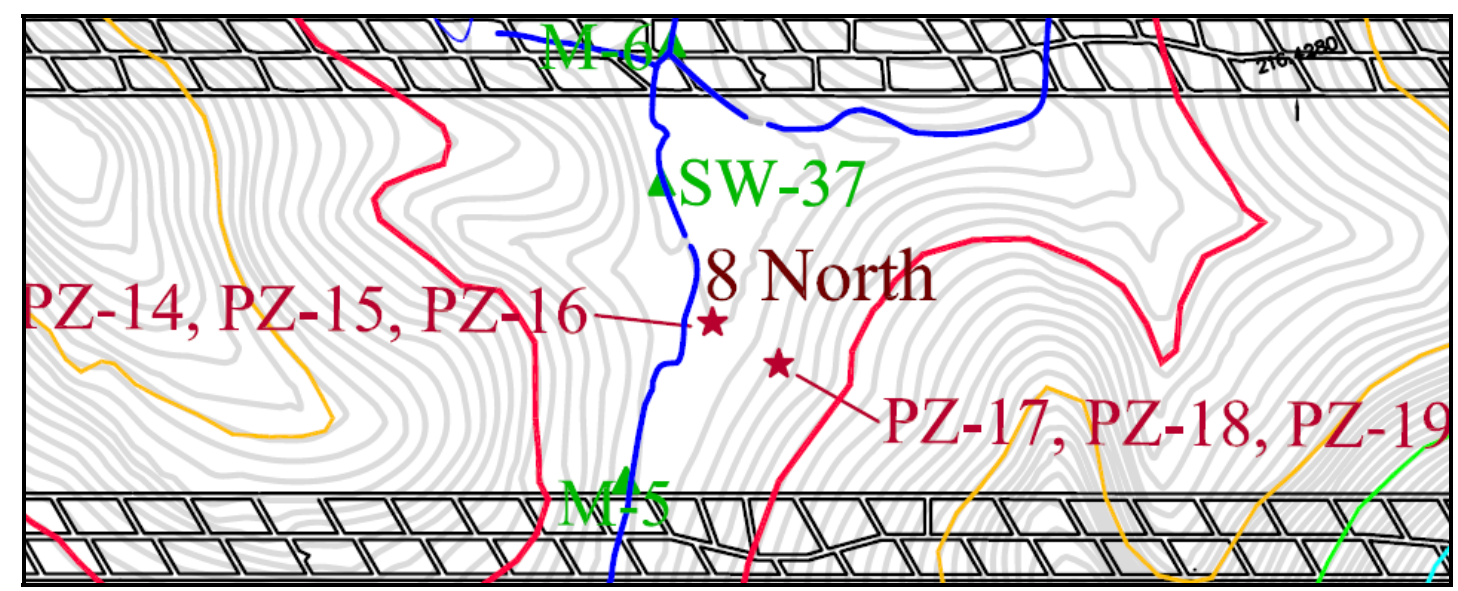

Figure 12 Site 7 location of PZ 14, 15, 16, 17, 18 and 19 in the 8 North panel

\subsubsection{Site 8:}

Site 8 is the last site. It is located in the 9 North panel and contains four piezometer wells, two located closer to the valley and two higher on the hillside slope (see Figure 13). PZ 22 and 23 are located near Laurel Run and are 364 feet from the 6 North panel headgate. PZ 20 and 21 are located on the hillside slope and are 369 feet from the 6 North panel headgate. There is nearly 150 feet between the hilltop and valley wells for this location. The depths of these wells in order are 86 feet, 20 feet, 50 feet, and 20 feet for PZ 20, 21, 22, and 23, respectively. The overburden thickness ranges from 443 feet for $P Z 22$ and 23 to 490 feet for $P Z 20$, and 21.

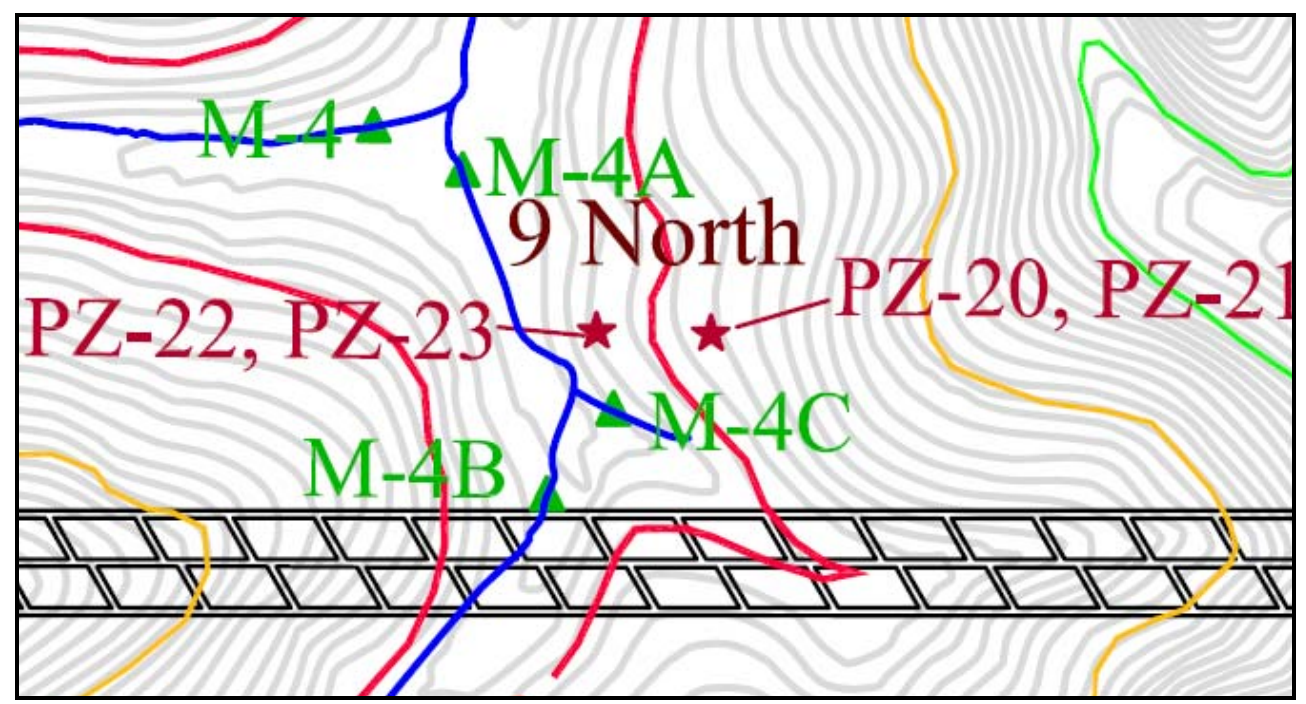

Figure 13 Site 8 location of PZ 20, 21, 22, and 23 in the 9 North panel 


\section{Chapter 4Results and Discussions}

\subsection{Groundwater Monitoring Data}

As mentioned in the "data collection" section, the data will be discussed in detail for all sites, addressing one site at a time. This section will progress southward through the sites in numerical order.

Also refer to Appendix 1: for a list of information for all the wells that describes their location, surface elevation, aquifer/aquitard thickness and so on. This table is intended to help the reader along in the report.

Each piezometer well has a monitoring zone or elevation range where groundwater is able to freely flow from the rock strata and be monitored. This zone is located in the bottom 12 feet of the well where the casing is slotted with a 0.2 inch slot. The well is grouted above the slotted casing to prevent water flow down the casing from the strata above. There is a filter pack (sand) packed between the slotted casing and the drilled hole wall to provide an area of good water flow and prevent any material from plugging the slotted casing. The water enters the casing and rises up the casing a certain distance that is equal to the pressure head for the aquifer or aquitard, whichever the strata may be.

In the following section, please note that only sandstone, limestone, and coal structures will be considered aquifers while all other shales and clays will be aquitards. When discussing the well monitoring zones, the aquifer thickness is only the thickness of the strata containing sandstones, limestones, and coal. If the monitoring zone includes an aquitard, this structure is not included because the limited porosity provided limited or hindered water flow.

This section will begin by describing the monitoring zone location and strata for each well and be followed by discussing the data in terms of groundwater elevation and how it changes over time for each site. Each site will have a series of graphs showing the data and will compare some findings relative to the geologic conditions per site. This section will conclude after discussing all 8 sites. 


\subsubsection{Monitoring Station Data}

Monitoring Zones:

PZ 31 had a depth of 20 feet from the surface. This well was located in nearly two feet of Waynesburg sandstone and 6 feet of Waynesburg coal. The coal seam does store and allow water flow but not in comparable amounts to sandstone. The sandstone served as the primary aquifer and was aided slightly by the coal. The interburden thickness between the sandstone and the Pittsburgh coal was 369.60 feet.

PZ 32 had a depth of 65 feet from the surface. PZ 32 was monitoring the Waynesburg limestone with a thickness of 4.85 feet. The interburden thickness between the aquifer and the Pittsburgh coal was 314.83 feet. The remaining portion of the monitoring zone was located in shale and claystones which did not provide adequate porosity for water flow and storage.

\section{Water Elevation Over Time:}

Presenting piezometer well data over time can show how each well is affected by mining neighboring panels, along with how the groundwater levels change for the life of the well. Fig. 12 shows the combined groundwater elevation data over time for Site1. While Figures 13 and 14 shows the expanded view for PZ 31 and 32, respectively. These graphs illustrate a time period from 2002 to 2004, showing data collection started 2 years after undermining near Site 1 . Looking at these graphs, the black dotted vertical lines are representing the dates when the longwall face undermined the stream in each of the longwall panels. Here it is easy to see the longwall face was six panels to the south when these wells began gathering data. The main purpose of these wells was to provide a better understanding of the aquifers reaction to the surface subsidence by using these wells (which did not subside) as a datum. 


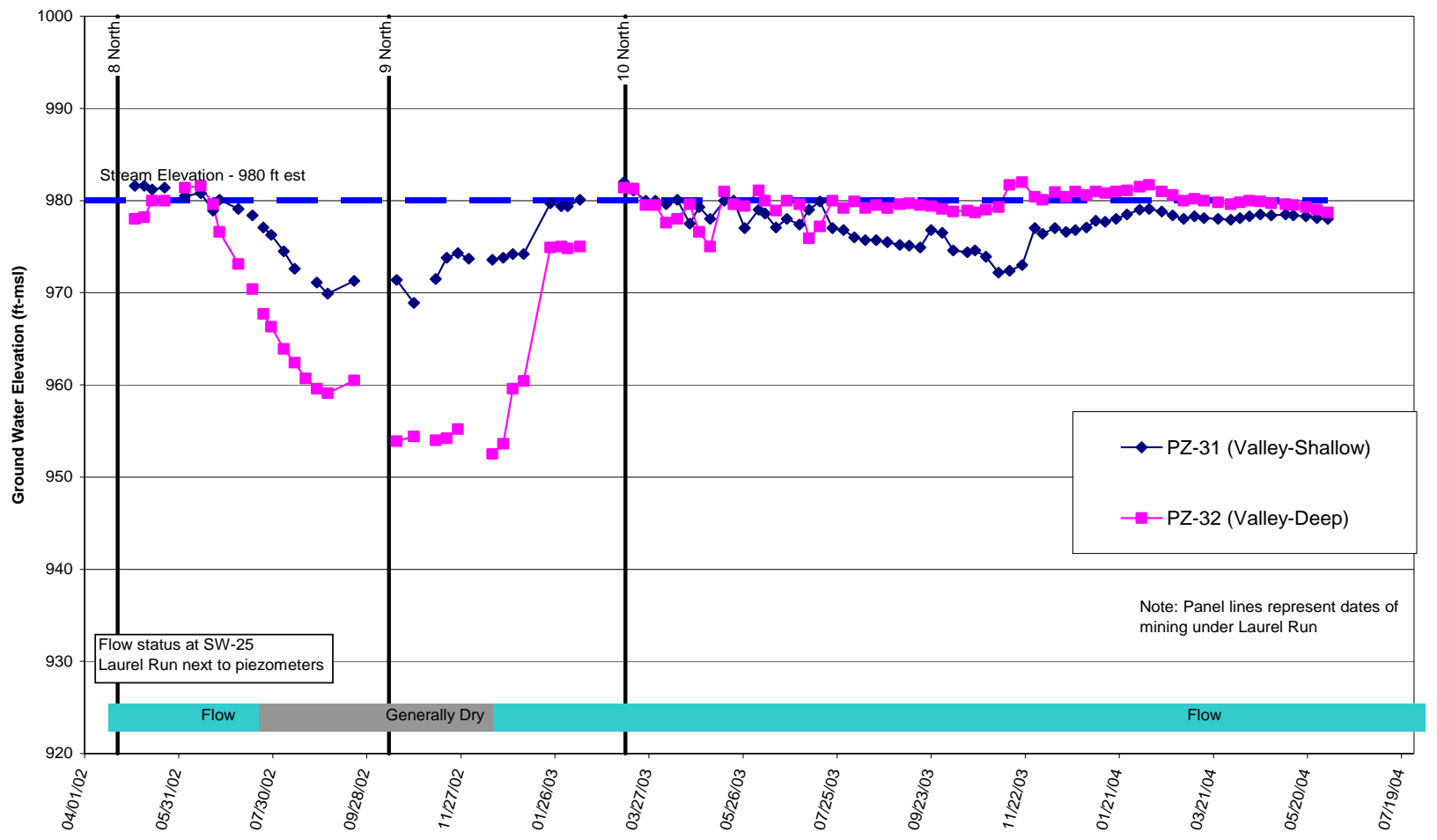

Figure 14 Combined groundwater elevation over time for Site 1 including stream flow data 


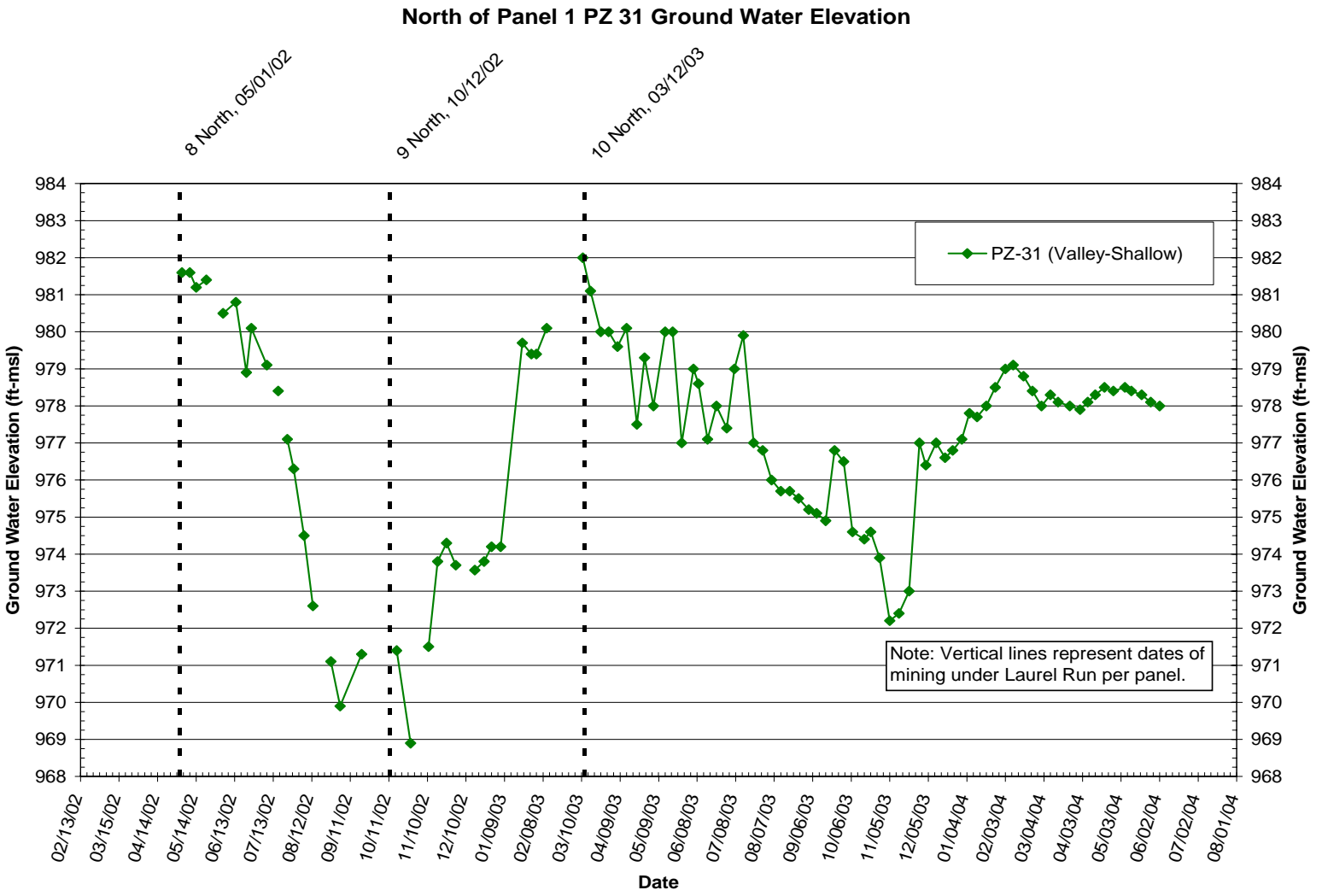

Figure 15 Groundwater elevation over time for PZ 31 of Site 1 


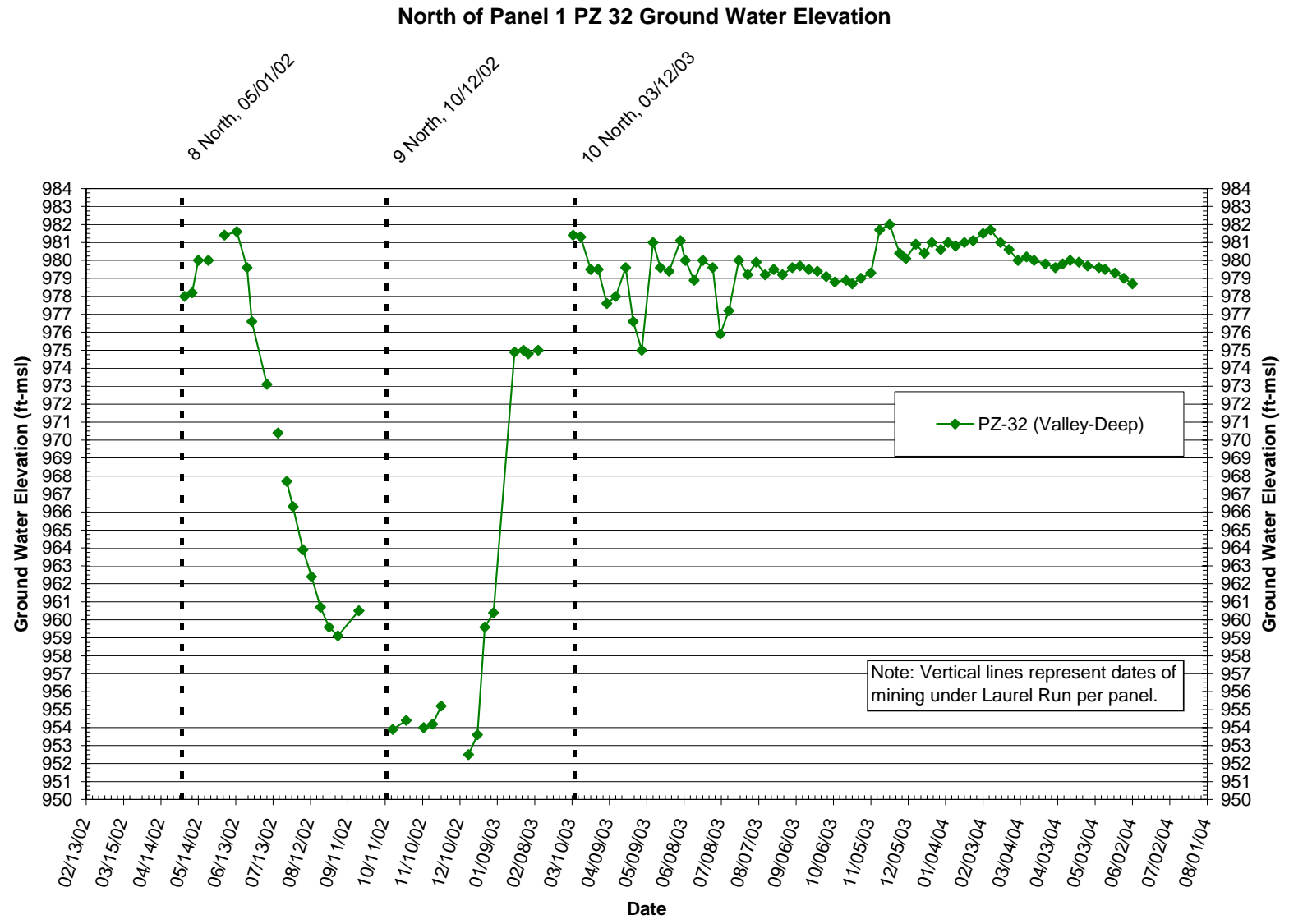

Figure 16 Groundwater elevation over time for PZ 32 of Site 1

Looking at the curves for PZ 31 and 32, the groundwater elevation shows some initial fluctuation in the graph before beginning to stabilize. Recall that these wells were located above an old gateroad system of another longwall panel district and not directly above a longwall panel and were never directly subsided.

Site one was monitoring two prominent aquifers but did not see the affects from subsidence like other sites.

\subsubsection{Site 2 Data:}

\section{Monitoring Zones:}

Site 2 contains PZ 1, 2, and 3; all of which are located in the valley on the surface. This site is unique because the piezometer depths range from 20 feet to 269 feet and provides a wide range of results. 
Starting with PZ 1, it is the shallow well with a depth of 20 feet. PZ 1 is monitoring the Waynesburg sandstone and the acting aquifer thickness is 16.5 feet. $P Z 1$ is monitoring the same sandstone as $P Z 31$ with the only difference being that PZ 1 is subject to subsidence when the 1 North panel was mined. PZ 1 has an interburden thickness of 368 feet between the aquifer and the coal seam.

PZ 2 is the intermediate well with a depth of 139.6 feet. This well is monitoring the Uniontown limestone which has a thickness of 12.8 feet. The interburden thickness between the limestone aquifer and the Pittsburgh coal is 314.8 feet. Looking at Map 2, the Uniontown limestone is the most massive formation and remains massive for the entire project area.

PZ 3 was the deepest well of Site 1 with a depth of 269 feet from the surface. This well is monitoring the Sewickley sandstone and is also the deepest well of all sites. The Sewickley sandstone is 14.4 feet thick in this area and produces an interburden thickness of 118 feet between the aquifer and the Pittsburgh coal.

\section{Water Elevation Over Time:}

Presenting piezometer well data over time can show how each well is affected by mining neighboring panels, along with how the groundwater levels change for the life of the well. Figure 15 shows all the Site 2 piezometer data over time. This graph is useful in comparing the wells in relation to elevation and water pressure head. In this graph, the blue dotted line represents the approximate stream elevation, and the light blue and gray boxes at the bottom stand for periods where the stream was dry or had flow to give some idea of recharge events or the stream condition. Figure 16 through 18 shows the same information but separates the wells for a closer look at the data with a different vertical axis scale and does not include stream data. These figures illustrate a time period from 1998 to 2004 , showing data that was collected 2 years prior to undermining Site 2 . The black vertical lines are representing the dates when the longwall face undermined the stream in each of the longwall panels. 
Panel 1 Piezometers Original Data Plot

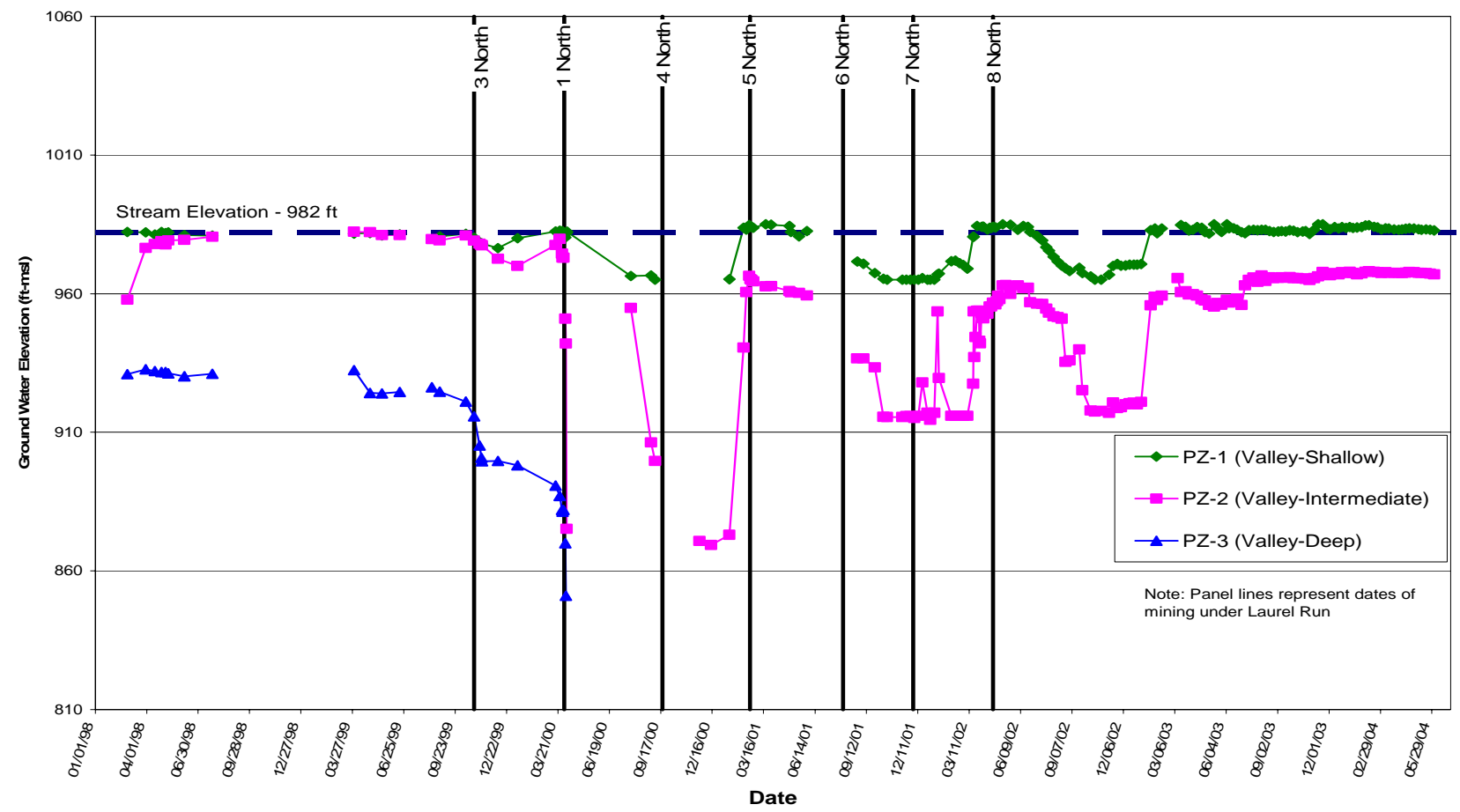

Figure 17 Combined groundwater elevation over time for Site 1 including stream flow data

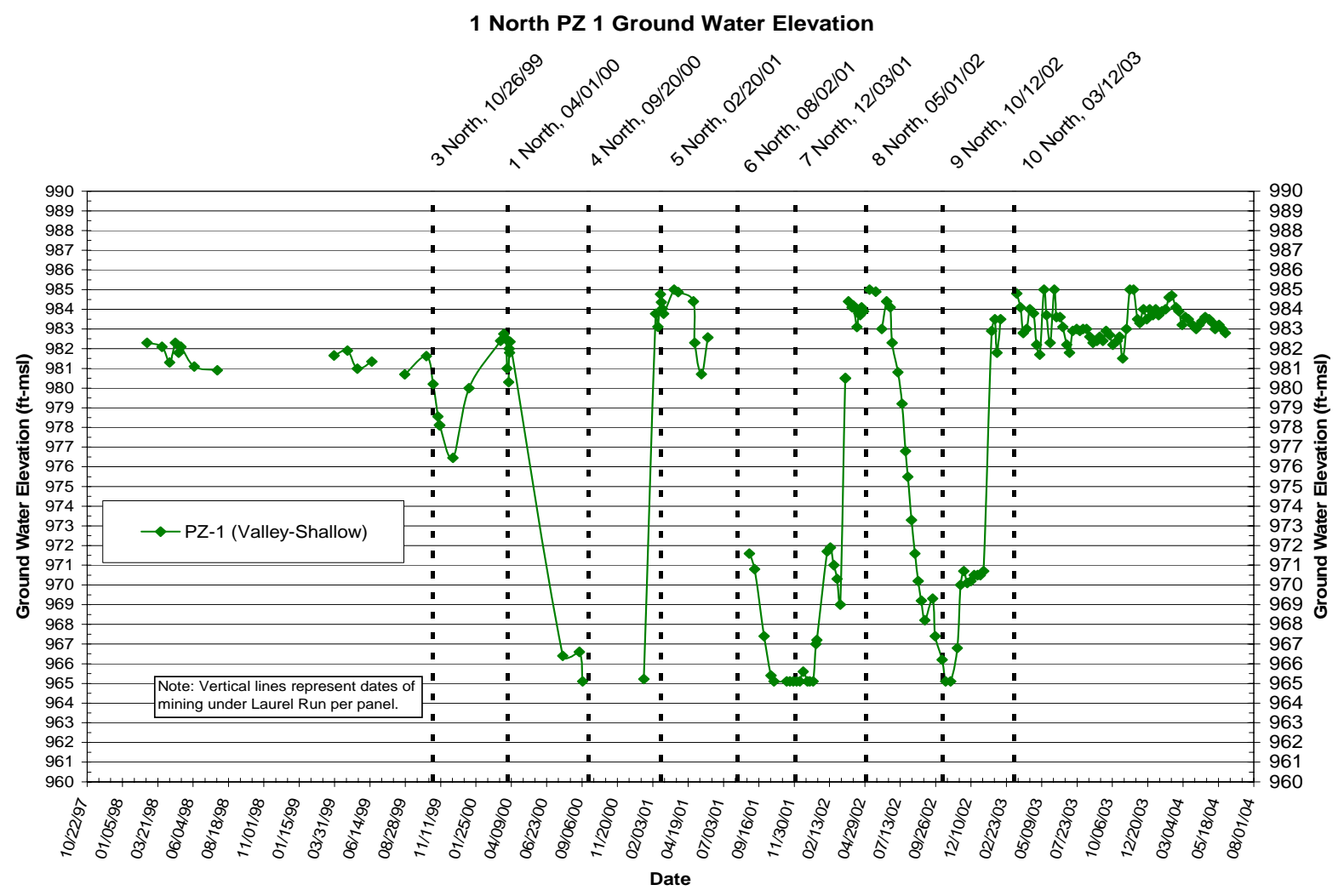

Figure 18 Groundwater elevation over time for PZ 1 of Site 2 
The green line is the groundwater elevation curve over time. Looking at the dashed line labeled 3 North on Figure 16, the sharp drop in the groundwater elevation is expected due to subsidence in the 3 North panel. Also, there is some visible evidence that this well elevation dropped some when the adjacent 4 North panel undermined the well. However, the remaining fluctuation in the curve between July 2001 and February of 2003 is not mining related since the active longwall face is 4,000 feet to 8,000 feet from the 3 North panel and Site 1 . Please refer to Map 1 for a better illustration of this distance.

PZ 2 is the intermediate well of Site 1 with a depth of 65 feet. Looking at figure 17, the curve for this well looks similar to the one for PZ 1; however, it shows a larger decrease in water elevation initially, and then it illustrates the same post mining fluctuation as $\mathrm{PZ} 1$.

\section{North PZ 2 Ground Water Elevation}
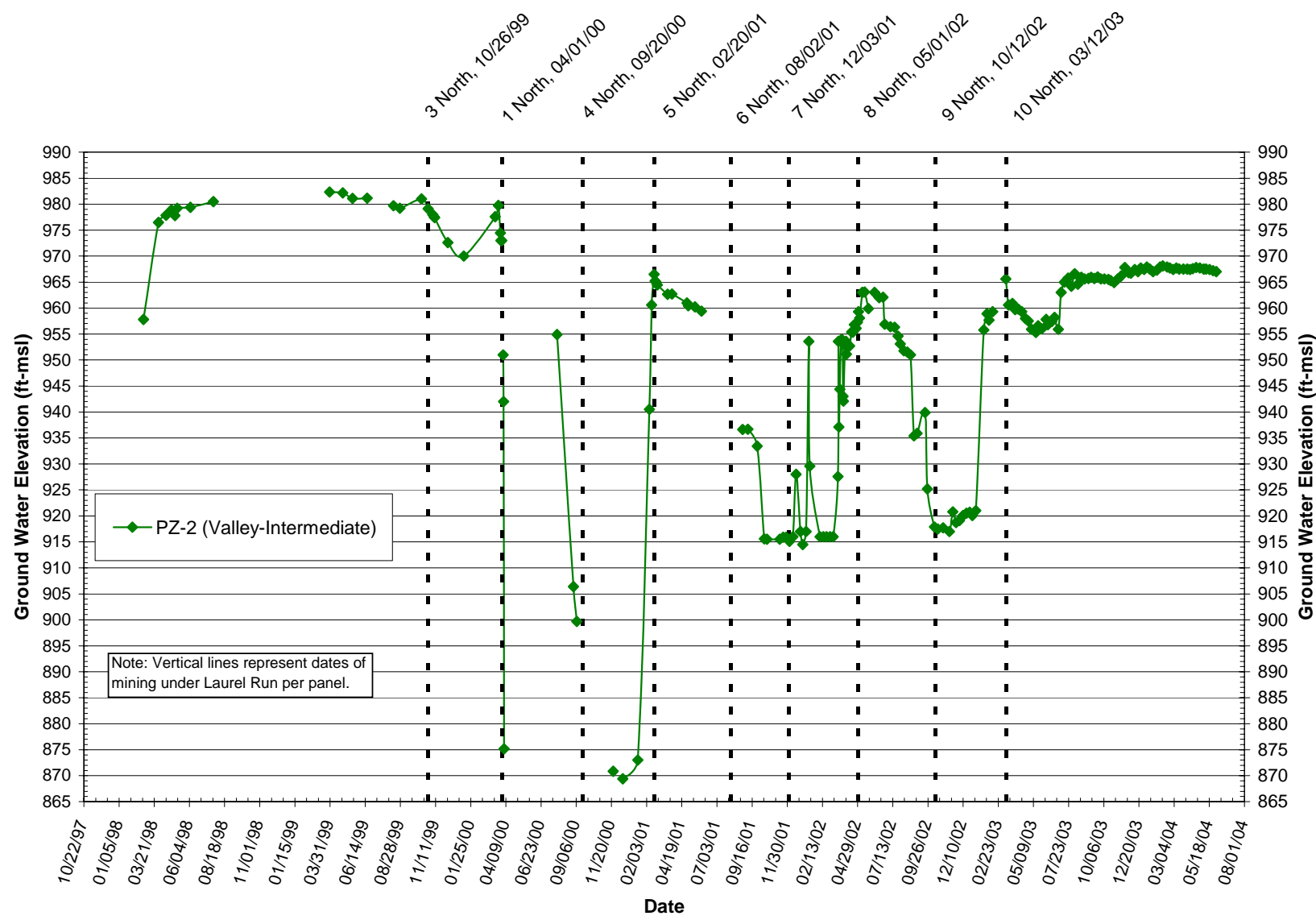

Figure 19 Groundwater elevation over time for PZ 2 of Site 2 
One noticeable difference is that from the beginning of 2001 to the last quarter of 2002 the maximum groundwater elevation during the fluctuation period produces a concave downward shape. Recalling that PZ 2 is monitoring limestone, this concave portion possibly points out the decreased water influx or indicates an inability to recharge as fast as the sandstone in PZ 1 . The limestone recharge difference could be caused by such a porosity difference and also location in reference to the surface or recharge source. Again, it can be said that the fluctuation shown after June 2001 is caused more by recharge events and less by mining related disturbances.

PZ 3 is the deepest of the three wells with a depth of 269 feet, casing bottom elevation of 725 feet, and interburden thickness of 118 feet between the sandstone aquifer and the Pittsburgh coal. Recalling that panel 3 North was mined before 1 North, looking at PZ 3 there is a noticeable effect of mining adjacent panels.

\section{North PZ 3 Ground Water Elevation}
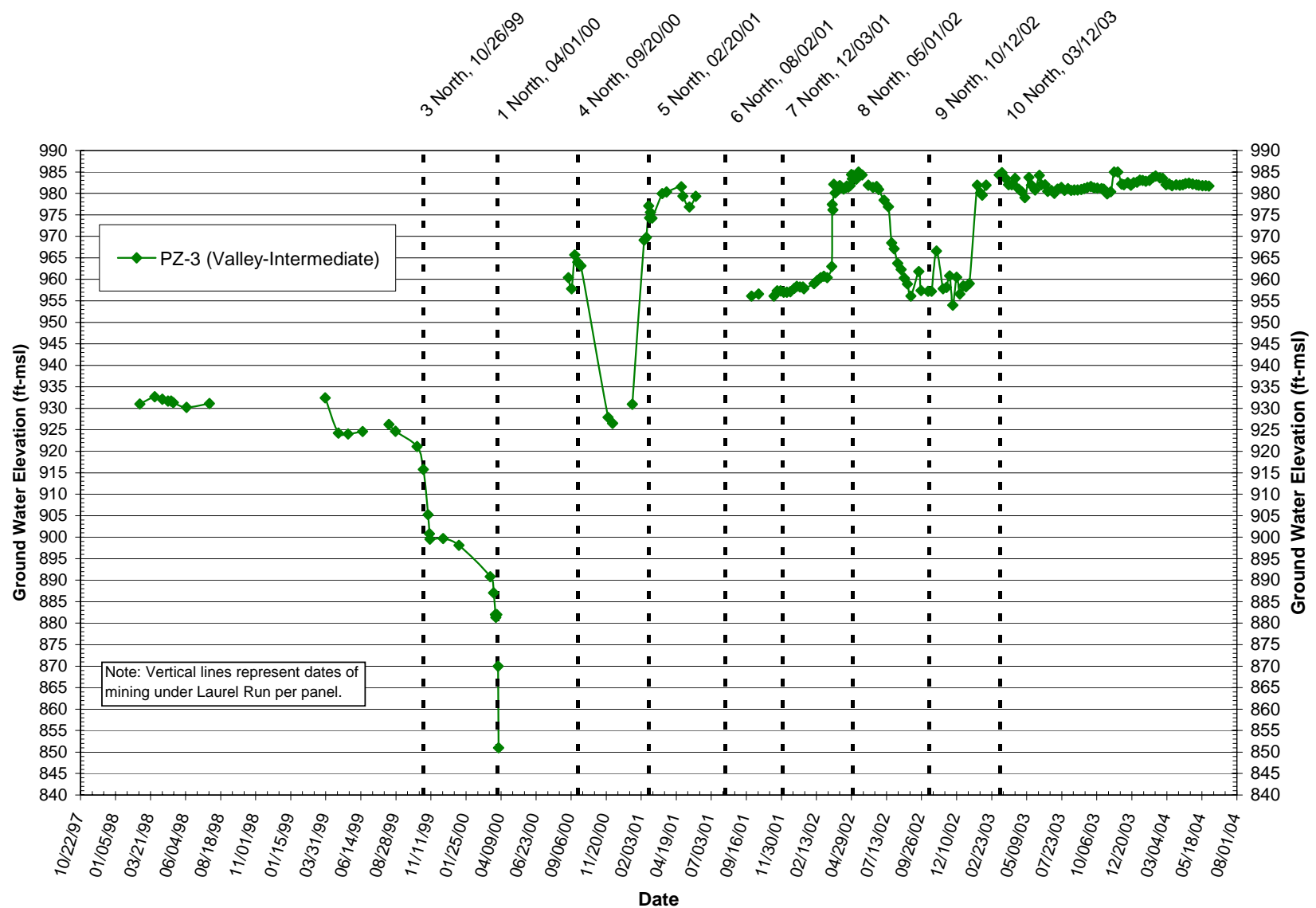

Figure 20 Groundwater elevation over time for PZ 3 of Site 2 
PZ 3 had a pre-mining water elevation nearly 922 feet and decreased to 900 feet when the 3 North face passes by PZ 3 in 1 North. As the face advances in 3 North, the water elevation begins to slowly drop three months before the face arrives adjacent to the well. The water elevation then stabilizes for a month before showing another declining period that exponentially declines when the 1 North face undermines the well. After undermining, the well goes dry for a five month period before recovering in September 2000. As the 4 North face undermines the stream, the water elevation drops again but does not go dry. This change in water elevation could have been influenced by subsidence however the active mining site is located nearly 3000 feet from the well. The fluctuation shown after June of 2001 is similar to what PZ 1 and 2 show for this site.

Further in time after mining of the 1 North panel finished, as the 4 North panel approached the stream, there was another distinct decrease in the PZ 2 water level to nearly 870 feet. This decrease potentially represents the effects of mining a panel located two panels below the location of the well in panel 1 North. A year after the 4 North panel approached the stream, the groundwater elevation of PZ 2 began to steadily increase to an elevation of 970 feet.

PZ 1 and 2 are the shallow wells of Site 1 . The groundwater levels for these wells increased slightly by 5 feet prior to the arrival of the longwall face. PZ 3 is the deepest well and shows a gradual decrease in groundwater elevation prior to the arrival of the longwall.

After the longwall face undermined the wells, PZ 2 and 3 decreased dramatically. Due to inadequate data, it is unknown if PZ 2 went dry or not for any period of time. Recalling Figures 15 through 18 of groundwater elevations over time, PZ 3 is located in the fracture zone of the longwall subsidence and was disrupted by the mining operation; however it recharged and stabilized to a level 30 feet higher than the well recorded prior to mining the area. PZ 1, however, showed little change as the longwall face passed and stabilized quickly. 


\subsubsection{Site 3 Data:}

\section{Monitoring Zones:}

Data for this site was collected from five wells; four wells located in the valley and one on the hillside slope. Please refer to Maps 1 and 2 to recall the location of the wells in this site and the geologic cross section.

PZ 4 was the shallowest valley well with a depth of 22.5 feet. The monitoring zone of the well was in a 6 feet region of soft dark gray claystone and 4 feet of hard, fractured gray carbonaceous sandstone known as the Waynesburg sandstone. The Waynesburg sandstone proved to be an adequate aquifer for this well to monitor.

PZ 5 was the original intermediate valley well with a depth of 142.5 feet. The monitoring zone of this well was located within two geologic layers. The upper layer was in 8 feet of non-fractured, dark gray limestone of the Uniontown limestone. The lower layer was 2 feet of soft shale and siltstone. Shale and siltstone stratum permeability is much less than that of sandstone and could have limited groundwater flow.

PZ 5A was the replacement valley intermediate well for PZ 5 with a depth of 60 feet, which is much shorter than the original. The monitoring zone of this well was located within two geologic layers. The upper layer was 7 feet of mediumhard, highly-fractured shaley sandstone of the Gilboy sandstone. The lower layer was 3 feet of soft shale and siltstone. Shale and siltstone stratum permeability is much less than that of sandstone and could have limited groundwater flow.

PZ 6 was the deepest valley well of Site 3 with a depth of 269.5 feet. The monitoring zone of this well was located within two geologic layers. The upper layer was 7.4 feet of medium-hard, non-fractured silty sandstone. The lower layer was 2.6 feet of medium-hard, highly fractured carbonaceous sandstone of the Sewickley sandstone. The highly fractured sandstone should be the primary strata for this well to monitor from.

PZ 8 was the hillside well of Site 3 with a depth of 70 feet. This well was monitoring 10 feet of hard, fractured gray carbonaceous sandstone known as the 
Waynesburg sandstone. The Waynesburg sandstone proved to be an adequate aquifer for this well to monitor.

\section{Water Elevation Over Time:}

Presenting piezometer well data over time can shows how each well is affected by mining neighboring panels, along with how the groundwater levels change for the life of the well. Figure 3 is a combined graph of all piezometer wells for this site. The black vertical lines are representing the dates when the longwall face undermined the stream in each of the longwall panels. This combined plot does not include the stream condition along the bottom of the chart. The red, purple, green, blue, and light blue lines represent $P Z 4,5,5 \mathrm{~A}, 6$, and 8 groundwater elevation changes over time. This graph illustrates a time period from 1998 to 2004, showing data that was collected 3 years prior to undermining Site 3. No stream data will be presented with this sites original data plot.

\section{Panel 4 Piezometers Original Data Plot}

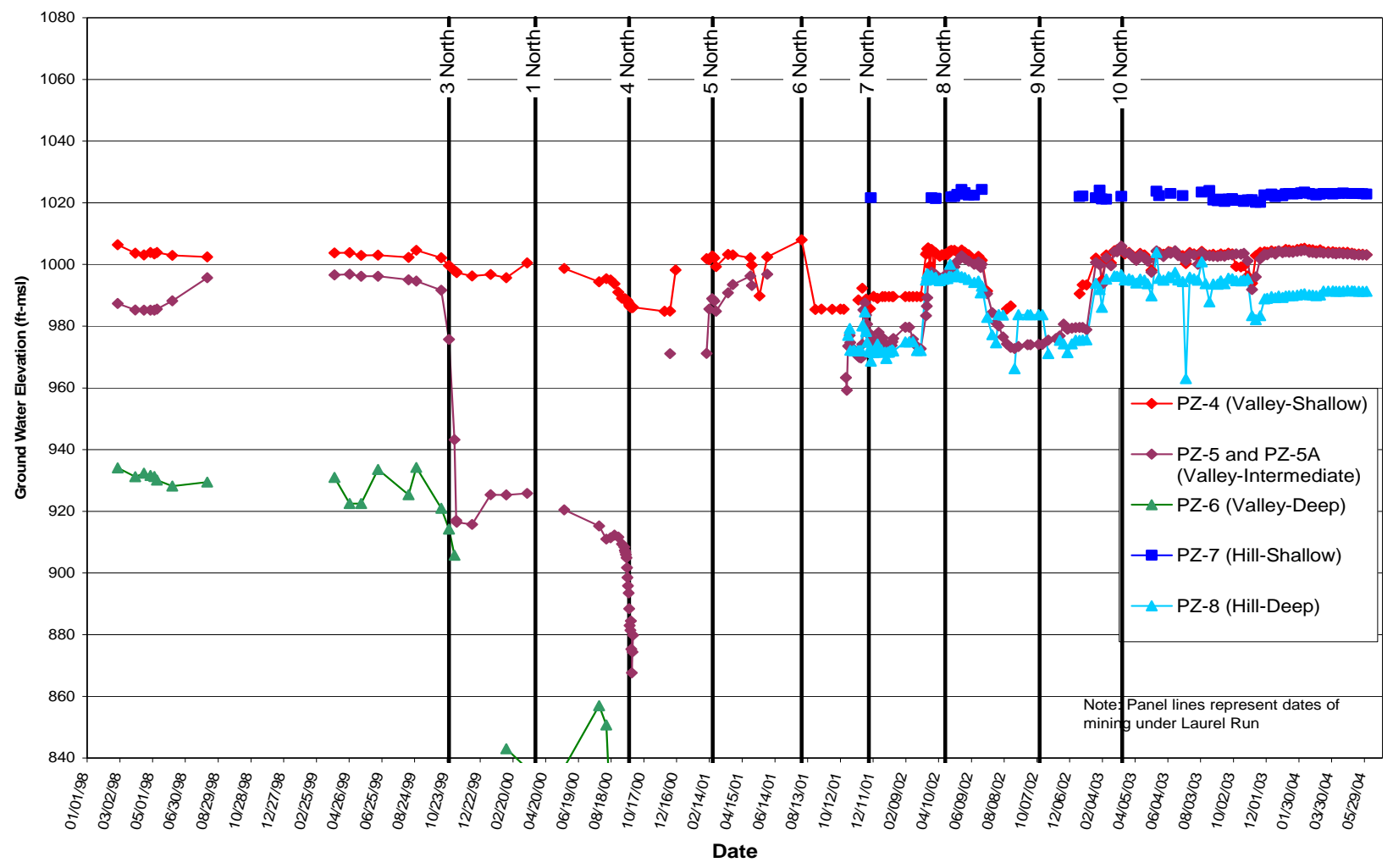

Figure 21 Combined groundwater elevation over time for Site 3 


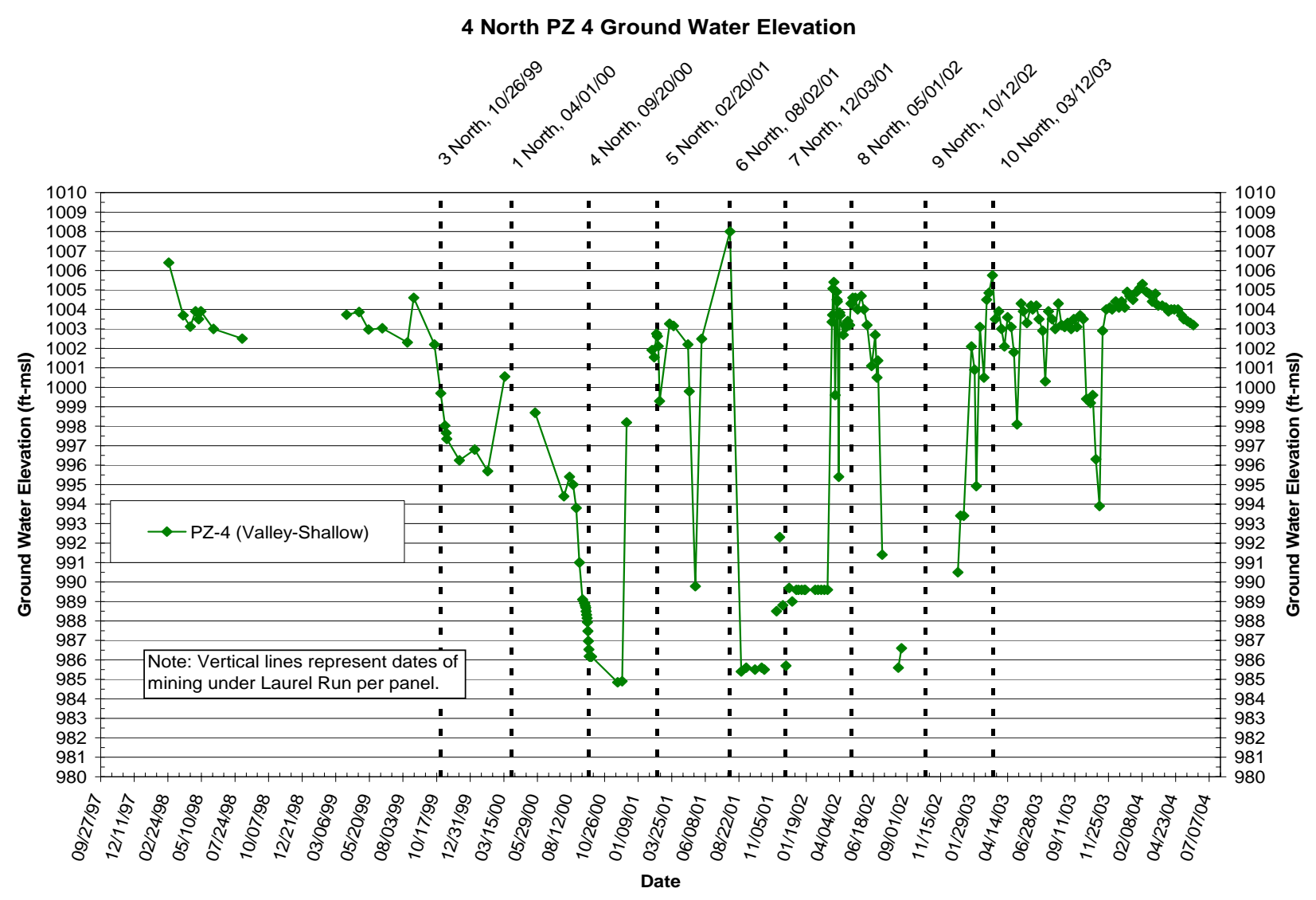

Figure 22 Groundwater elevation over time for PZ 4 of Site 3

Figure 22 through Figure 26 show the piezometer water elevation data over time for Site 3. These hydrographs illustrate the changes in groundwater elevation from 1998 to 2004, showing data that was collected 3 years prior to undermining Site 3.

PZ 4 was the shallowest valley well of Site 3 with a depth of 22.5 feet, casing bottom elevation of 970 feet, and interburden thickness of 369 feet between the aquifer bottom and the Pittsburgh coal seam (see Figure 22). This well had a groundwater elevation of nearly 1,003 feet prior to mining both 3 North and 1 North panels. After the face undermines the wells in both 3 North and 1 North panels, the well groundwater elevation lowered approximately to 995 feet. As PZ 4 was undermined by the 4 North face, the well encountered only a small decrease of 10 feet to 985 feet. After the end of a dry spell in March of 2001, the groundwater recharged to original levels. From March of 2001 to March of 2003, the well 
trended along with stream flow or groundwater recharge event occurrences. PZ 4 appeared to stabilize after March of 2003, often times to levels greater then premining levels. PZ 4 data reported similar results to PZ 1 of Site 1.

From a weather point of view, refer to Appendix 2: for an illustration of the precipitation and stream flow data from 1998 through 2004. Notice the spikes on this chart as they represent periods of substantial rainfall that serve as recharge events for the aquifers in this area. Also notice the correlation between the dates of the precipitation and the height of the water column. Most of the water elevation changes shown on the hydrographs for this site appear to be a result of weather affects or recharge periods and the lower level periods seem to correlate with dry periods during the summer and winter months.

PZ 5 was the intermediate valley well for Site 2 with a depth of 142.4 feet, casing bottom elevation of 865 feet, and interburden thickness of 234.5 feet (see Figure 23). The well groundwater elevation prior to mining was near to the stream elevation of 1,005 feet.

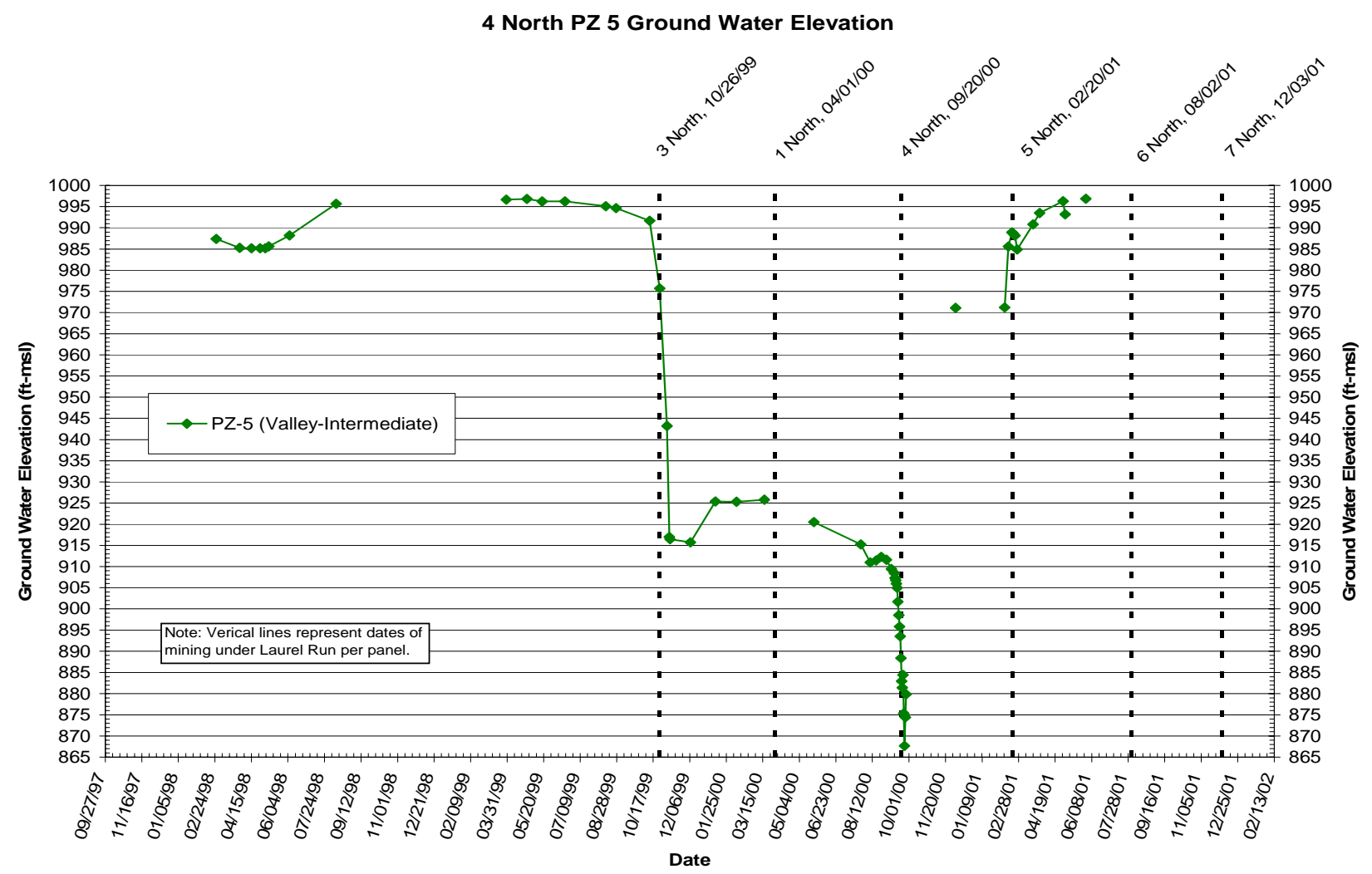

Figure 23 Groundwater elevation over time for PZ 5 of Site 3 
As the face approached the stream in the 3 North panel, the groundwater level decreased to as low as 915 feet but increased to 927 feet before the 1 North panel face arrived. The well groundwater elevation of PZ 5 decreased to 920 feet as the 1 North panel face approached the stream. As the 4 North longwall face approached the stream near Site 2, PZ 5 decreased to immeasurable levels and was abandoned due to an obstruction (see Figure 23).

PZ 5A (a post-mining piezometer well) data began in December of 2000 and continued through 2004 (see Figure 24). Recalling the monitoring zone discussion for this well, please take note that this well is monitoring several strata layers that are aquitards and does not include any strata that is considered an aquifer. Also, there is a difference of 80 feet in depth between PZ 5 and 5A. PZ 5A well had a depth of 60 feet, casing bottom elevation of 947 feet, and interburden thickness of 317 feet. The PZ 5A well data seemed to fluctuate but not in direct response to the location of the active mining face throughout the area. PZ 5A appeared to normalize by April of 2003, which is three years after the 4 North panel was mined.

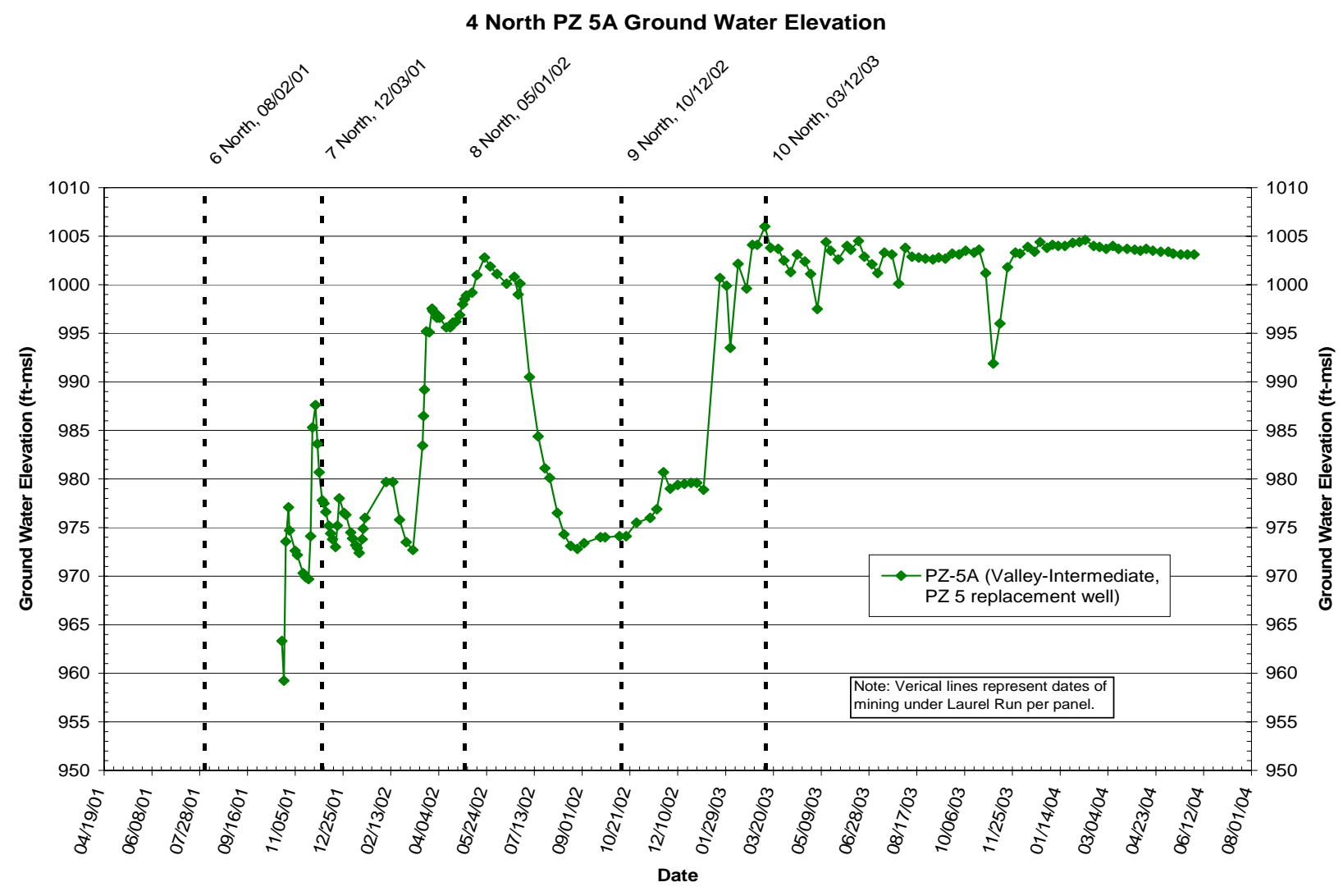

Figure 24 Groundwater elevation over time for PZ 5A of Site 3 
PZ 6 was the deepest of the three valley wells with a depth of 269.5 feet, casing bottom elevation of 737.5 feet (see Figure 25). Recalling that panel 3 North was mined before 1 North, looking at PZ 6 data, there was a noticeable affect of mining panels before 4 North. PZ 6 had a pre-mining water elevation nearly 930 feet and decreased below 905 feet when 3 North was mined and did not rebound much while mining 1 North panel. As the longwall face of 4 North approached the well, the water level slowly began to lower 2 months before the face arrived. When the 4 North panel longwall face arrived, the well groundwater level decreased immediately to immeasurable levels and began to rebound four months later. PZ 6 well was found obstructed, and the well was abandoned near the end of the 4 North Panel.

4 North PZ 6 Ground Water Elevation

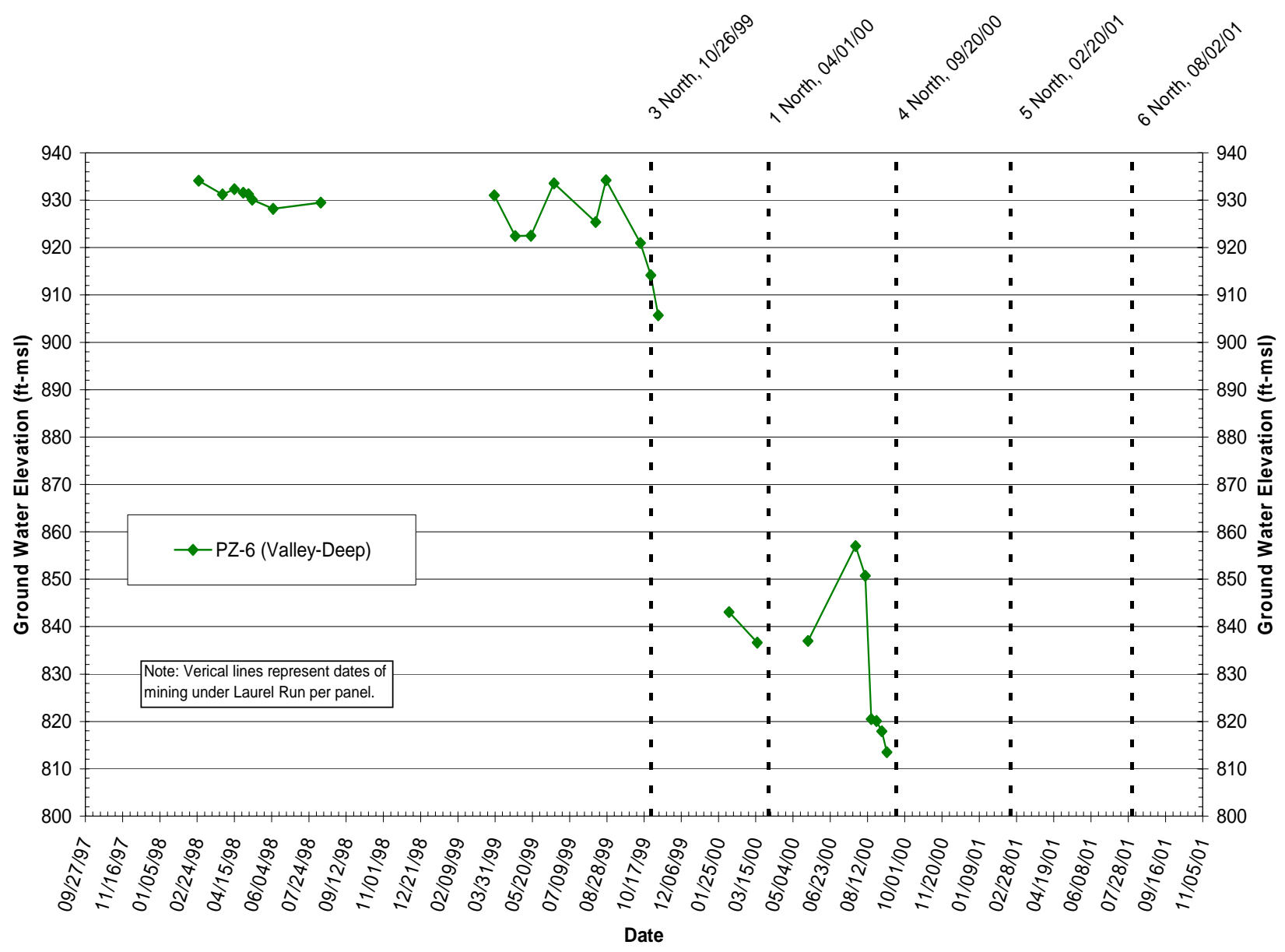

Figure 25 Groundwater elevation over time for PZ 6 of Site 3 
PZ 8 is the hillside well for site 3 with a depth of 70 feet, casing elevation of 975 feet, and interburden thickness of 371.5 feet between the sandstone aquifer and the Pittsburgh coal seam. The aquifer thickness is 31.3 feet in this area. Looking at Figure 26, PZ 8 was placed in operation near the end of 2001 well after mining ended in the 4 north panel. This curve shape very closely resembles what the wells in 1 North of Site 2 produced; showing some similarity to weather patterns or stream flow events. Please refer Appendix 1: to compare the groundwater elevation for PZ 8 and the precipitation. And please notice that the time periods of dry weather occur at the same time as the periods of low groundwater elevation from the middle of 2001 to middle of 2004.

\section{North PZ 8 Ground Water Elevation}

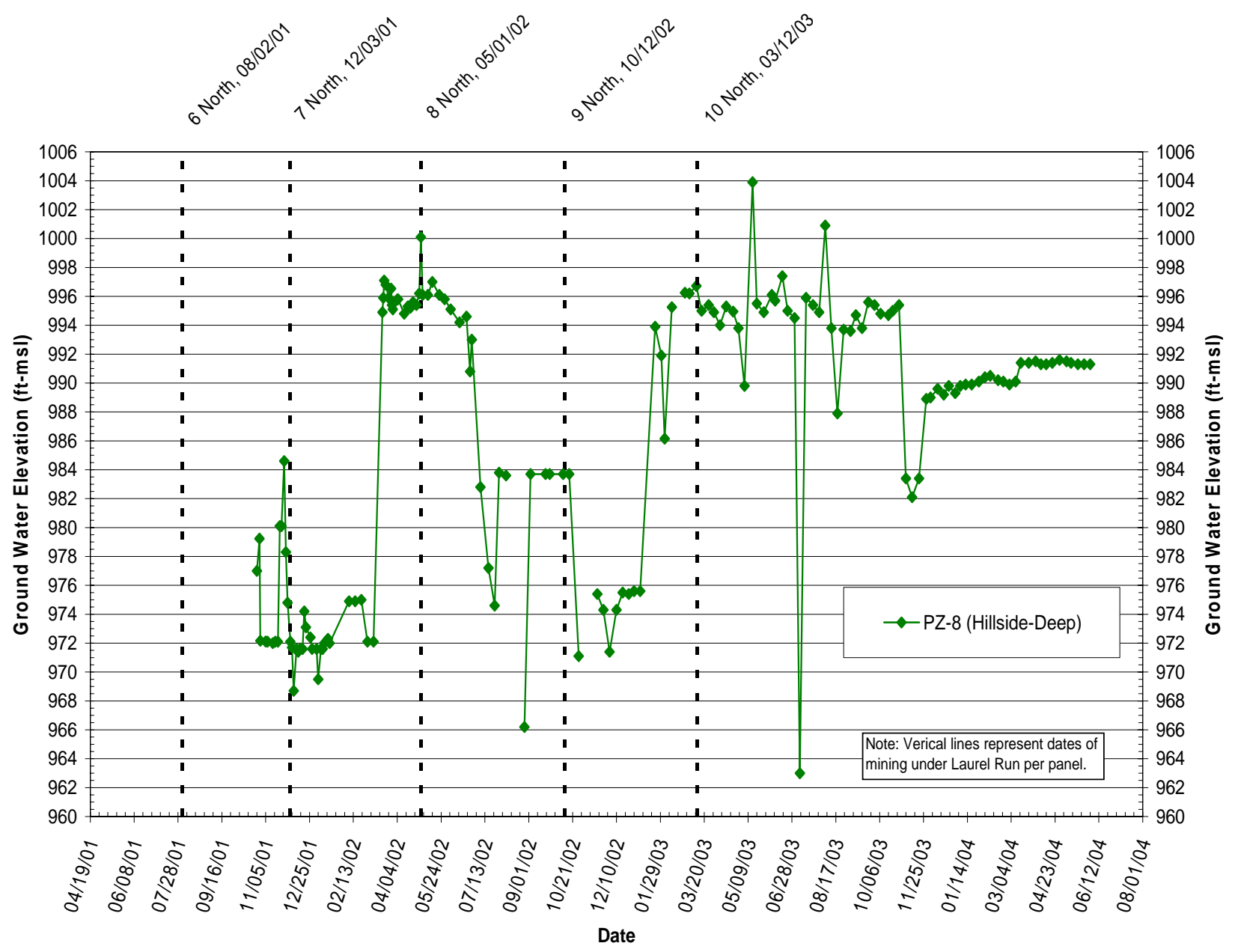

Figure 26 Groundwater elevation over time for PZ 8 of Site 3 


\subsubsection{Site 4 Data:}

\section{Monitoring Zones:}

Data for this site is from three wells; two wells are located in the valley near the stream and the third one located near an un-named tributary of Laurel Run. Please refer to Maps 1 and 2 to recall the location of the wells in the site and the geologic cross section.

PZ 26 was the most shallow well with a depth of 40 feet from the surface. This placed the entire 12 monitoring zone of the well into the Waynesburg sandstone. In this area, the Waynesburg sandstone thickness is 36.75 feet. The interburden thickness between the sandstone aquifer and the Pittsburgh coal seam is 389 feet.

PZ 27 was the intermediate well with a depth of 80 feet from the surface. The monitoring zone of this well was located in 5 feet of Waynesburg coal. The coal aquifers are the lowest quality aquifer but still provide substantial water flow through various bedding planes and butt and face cleats in the coal formations. The Waynesburg coal is located 331 feet up from the Pittsburgh coal seam.

PZ 28 was the deepest well of Site 4 with a depth of 60 feet from the surface. The monitoring zone of this well was located in 12 feet of soft gray clay shale and will not be considered an aquifer. The graph for this well will be included in the next section but will not be discussed in great detail.

\section{Water Elevation Over Time:}

PZ 26 through 27 monitored Site 4 from April 2002 to June 2004, meaning data collection began over a year after the longwall undermined the area. The data collected from this area can be useful to help separate the mining related effects from the weather or recharge affects in the project area. Figure 27 is the combined chart of PZ 26 and 27 located in the un-named tributary of Laurel Run. 


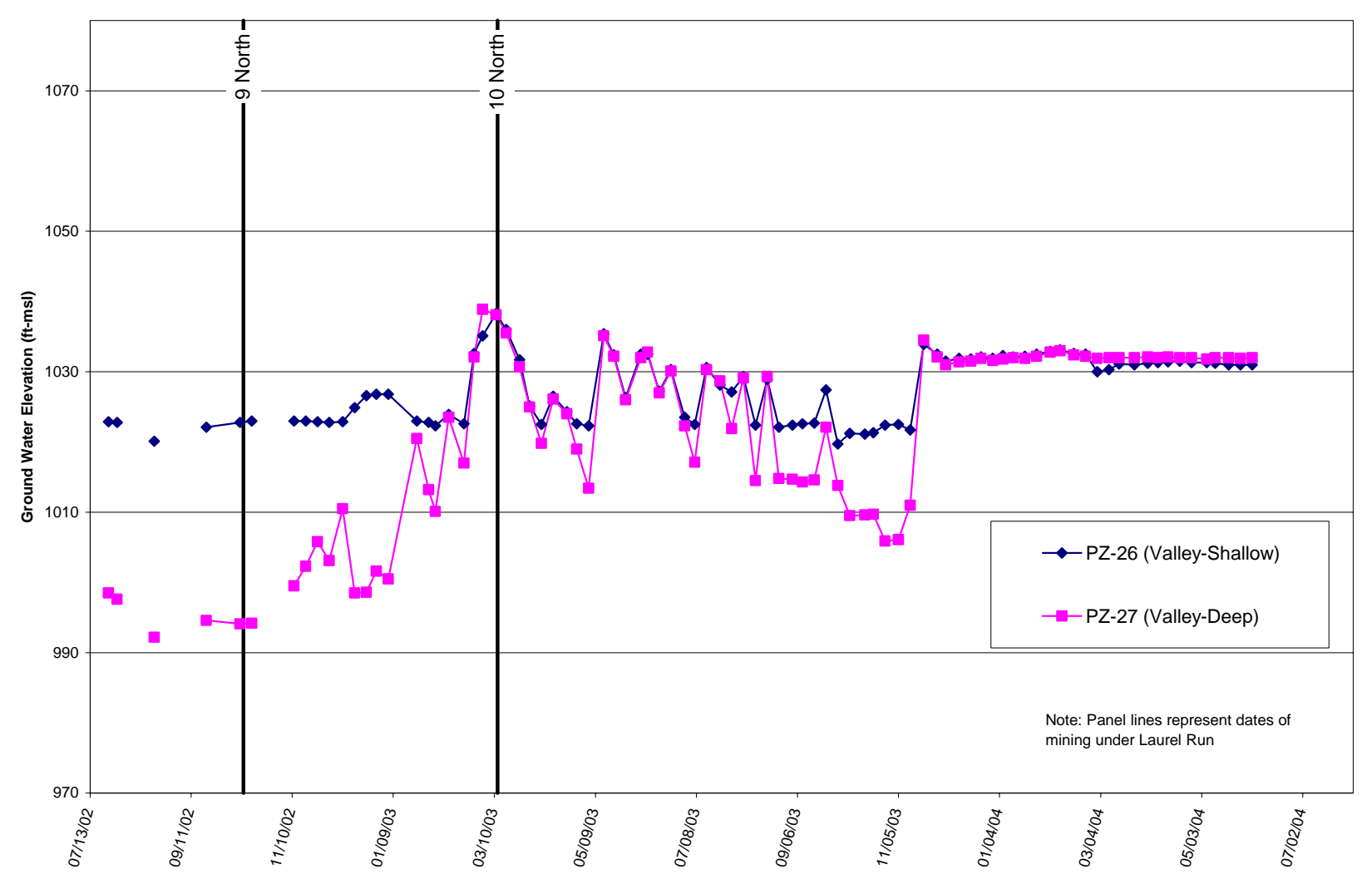

Figure 27 Combined groundwater elevation over time for Site 4

Looking at Figure 27, both wells appear to follow very similar trends over time with a difference in elevation between the wells equal to the difference in well depth from 2002 to 2003 . After 2003, both wells begin to equalize and report the same groundwater elevation. These curves do not appear to show any distinct correlation to dry or wet weather seasons, however also do not show any immediate drops in groundwater elevation due to mining because the active longwall face is 1.5 years ahead of the area or nearly 4 panels ahead of the area when data recording began for Site 4 .

Discussion about Site 4 will end here because there is not any evidence of mining related disruption to the site. Rather, the little fluctuation in the curves represents the possible changes in weather effects or aquifer recharge events. Lastly, these curves show the wells for Site 4 fully stabilize by the beginning of 2004, which is nearly three years after mining moved through this area. 


\subsubsection{Site 5 Data:}

\section{Monitoring Zones:}

Data for this site is from four wells; two wells are located in the valley near the stream and two wells are located on the hillside.

PZ 9S was a shallow valley well with a casing depth of 19.58 feet from the surface, casing bottom elevation of 1,018.4 feet, and an interburden thickness of 389.3 feet from the aquifer to the Pittsburgh coal seam. The PZ 9S monitoring zone is located completely in the Waynesburg sandstone. There it is 51.4 feet thick.

PZ 9D was a deep valley well with a casing depth of 58.8 feet from the surface, casing bottom elevation of 979.3 feet, and an interburden thickness of 389.3 feet. This is similar to PZ 9S because both are monitoring the Waynesburg sandstone.

PZ 10 was a shallow hillside well with a casing depth of 19.8 feet from the surface, casing bottom elevation of 1040.21 feet, and an interburden thickness of 411.2 feet from the aquifer to the Pittsburgh coal seam. The PZ 10 monitoring zone is located in 4.5 feet of the Calvin Run limestone.

PZ 11 was a deep hillside well with a casing depth of 76.7 feet from the surface, casing bottom elevation of 983.3 feet, and an interburden thickness of 392.75 feet between the aquifer and the Pittsburgh coal seam. This well is monitoring the Waynesburg sandstone with a thickness of 47.1 feet in the area.

\section{Water Elevation Over Time:}

Figure 28 is a combined graph of all piezometer wells for this site located in the 6 North panel. Looking Figure 26, the black vertical lines are representing the dates when the longwall face undermined the stream in each of the longwall panels. This combined plot does not include the stream condition along the bottom of the chart. The blue, pink, green, and light blue lines represent PZ 9S, 9D, 10, and 11 groundwater elevation changes over time. This graph illustrates a time period from October 2001 to June 2004. Data collection began nearly two months after the site was undermined by the 6 North panel. 
Panel 6 Piezometers Original Plot

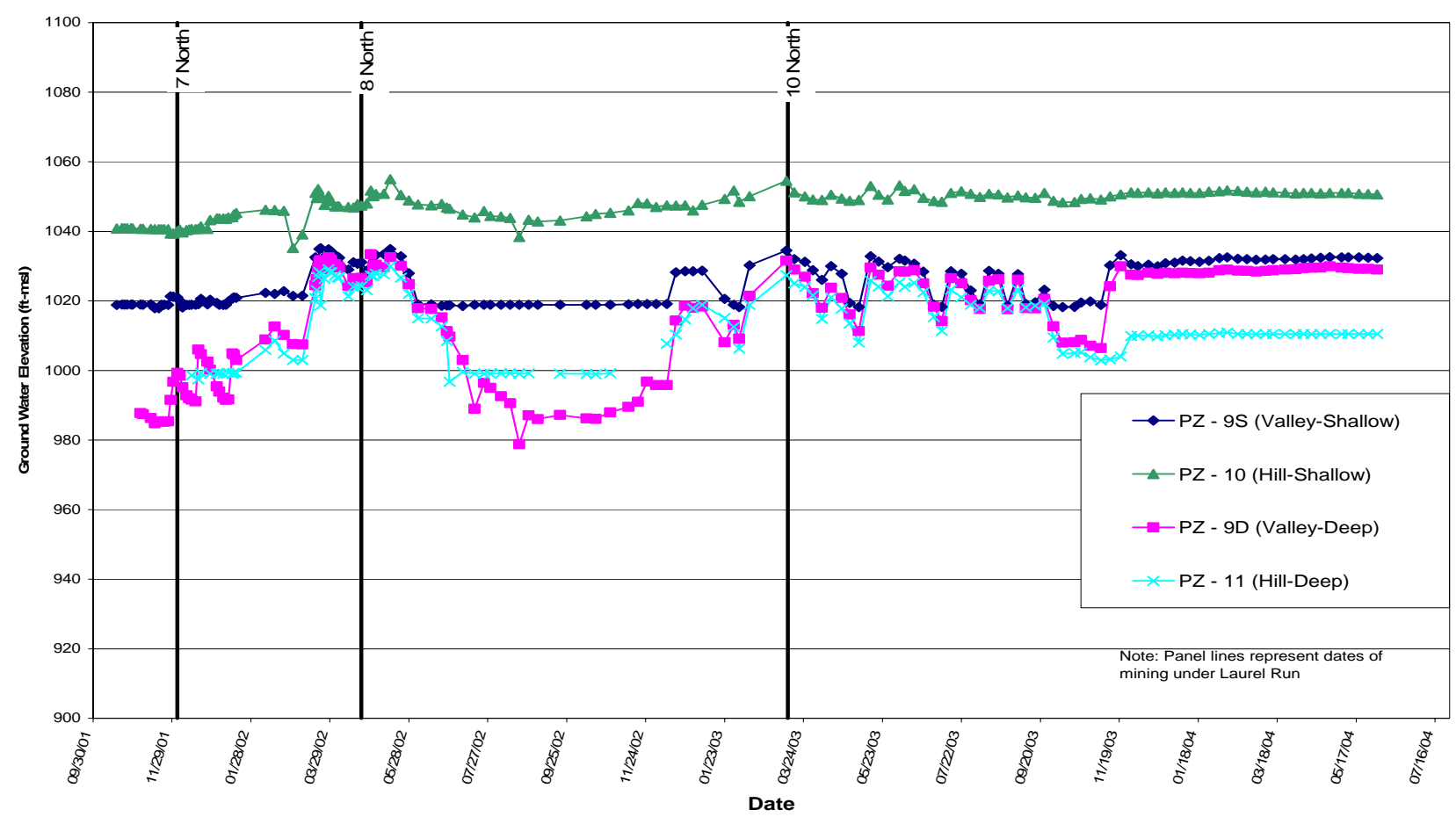

Figure 28 Combined groundwater elevation over time plot for Site 5

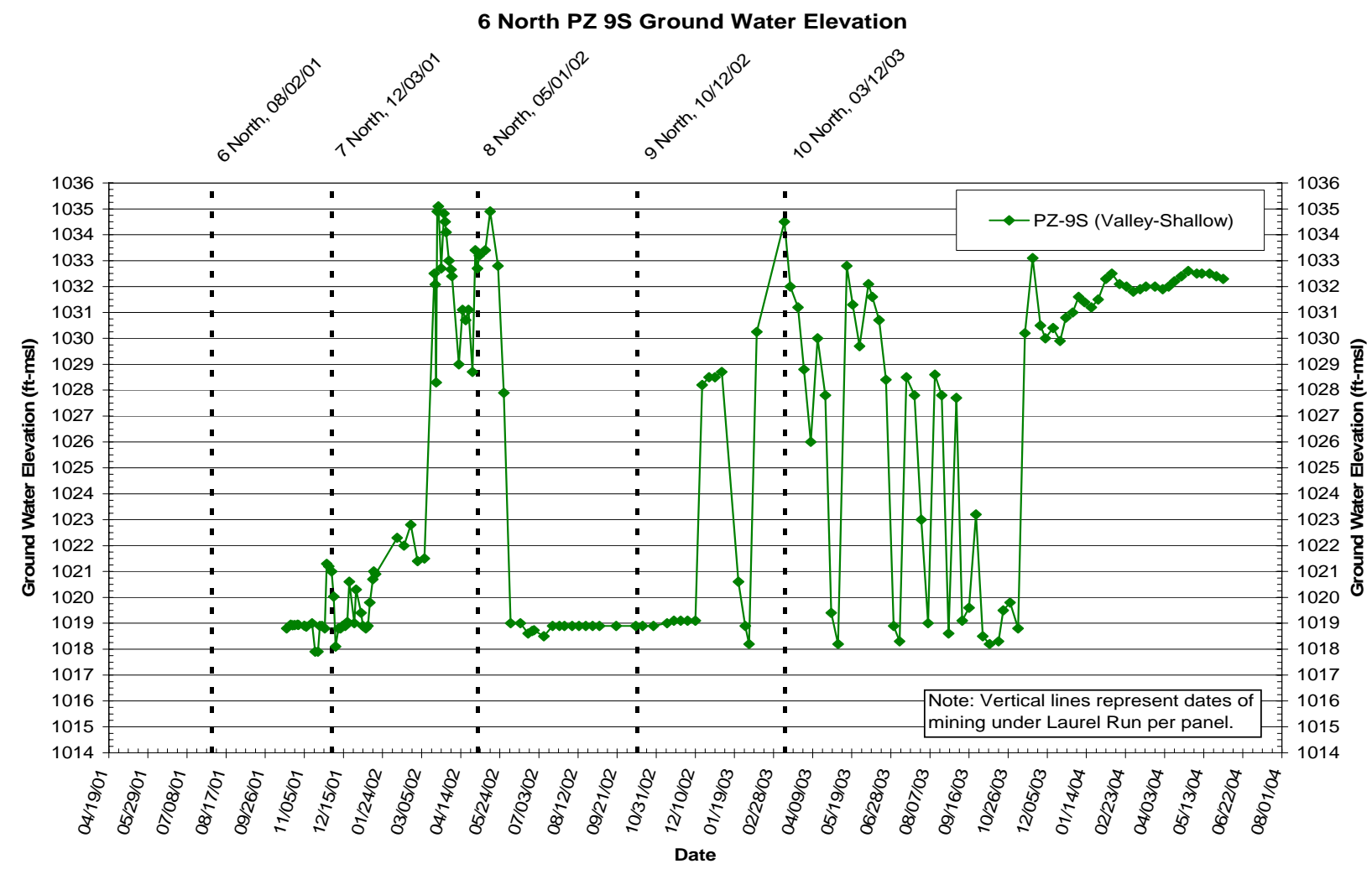

Figure 29 Groundwater elevation over time for PZ 9S of Site 5 
Data from PZ 9S, when compared to the precipitation data in Error! Reference source not found., coincides well with the weather data. For example, the large spike in the data from February 2002 to June 2002 follows directly with the stream flow data, ultimately meaning this spike in the data is caused by the weather or aquifer recharge events. Looking at the group of spikes from December of 2002 through September 2003 and comparing them to the stream flow and precipitation data, once again there is clear correlation with the stream flow and weather data. Therefore, fluctuations in PZ 9S data are a result of precipitation and stream flow and not due to mining actions or subsidence.

The PZ 9D well has nearly the same conditions as PZ 9S in that they both are monitoring the same aquifer and only differ in depth. Looking at Figure 30, the data produced nearly a mirror image of PZ 9S and shows the same correlation with precipitation and stream flow as Figure 29.

6 North PZ 9D Ground Water Elevation

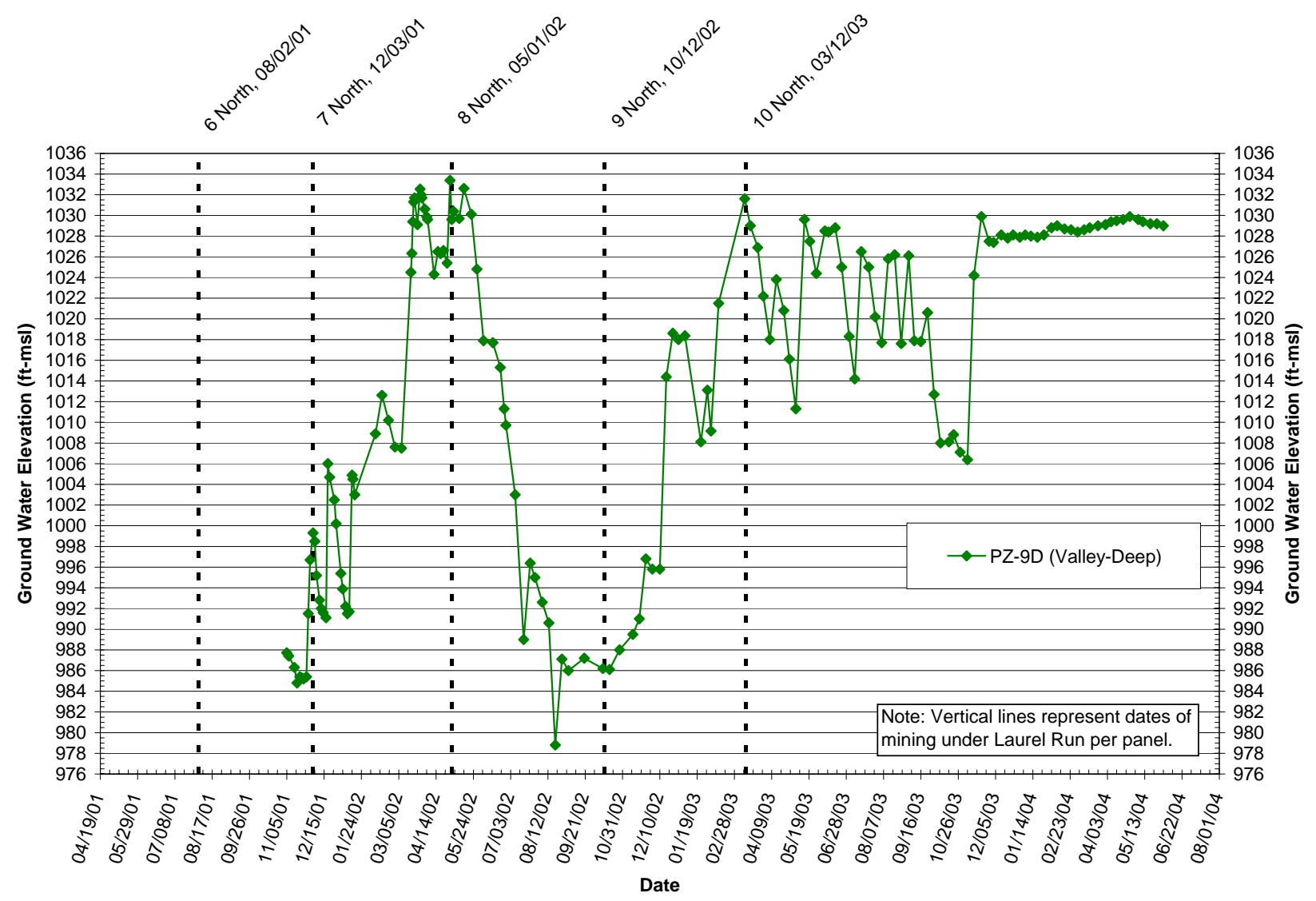

Figure 30 Groundwater elevation over time for PZ 9D of site 5 
Data from PZ 10 when plotted also looks similar to both PZ 9S and 9D, without any sharp or large spikes. This curve appears smoother in nature because the monitoring zone for PZ 10 is located in 5 feet of limestone, which has less porosity and is surrounded by aquitards consisting of clay shale with an even lesser porosity. However, even through the limestone is located in between these two aquitards, the curve still follows the same trend as the valley wells monitoring the sandstone aquifer.

PZ 11 is the deepest hillside well of Site 5 that is also monitoring the Waynesburg sandstone, which is the same sandstone as PZ 9S and 9D. Looking at Figure 31 of the groundwater elevation over time for PZ 11, there are some differences between the fluctuations seen in PZ 11 and those in PZ 9S and 9D. The correlation between groundwater elevation and the weather and stream flow still exists; however, the portion of the curve where the groundwater elevation stabilizes is nearly 12 feet lower than the average maximum spike during the period where the data fluctuated.

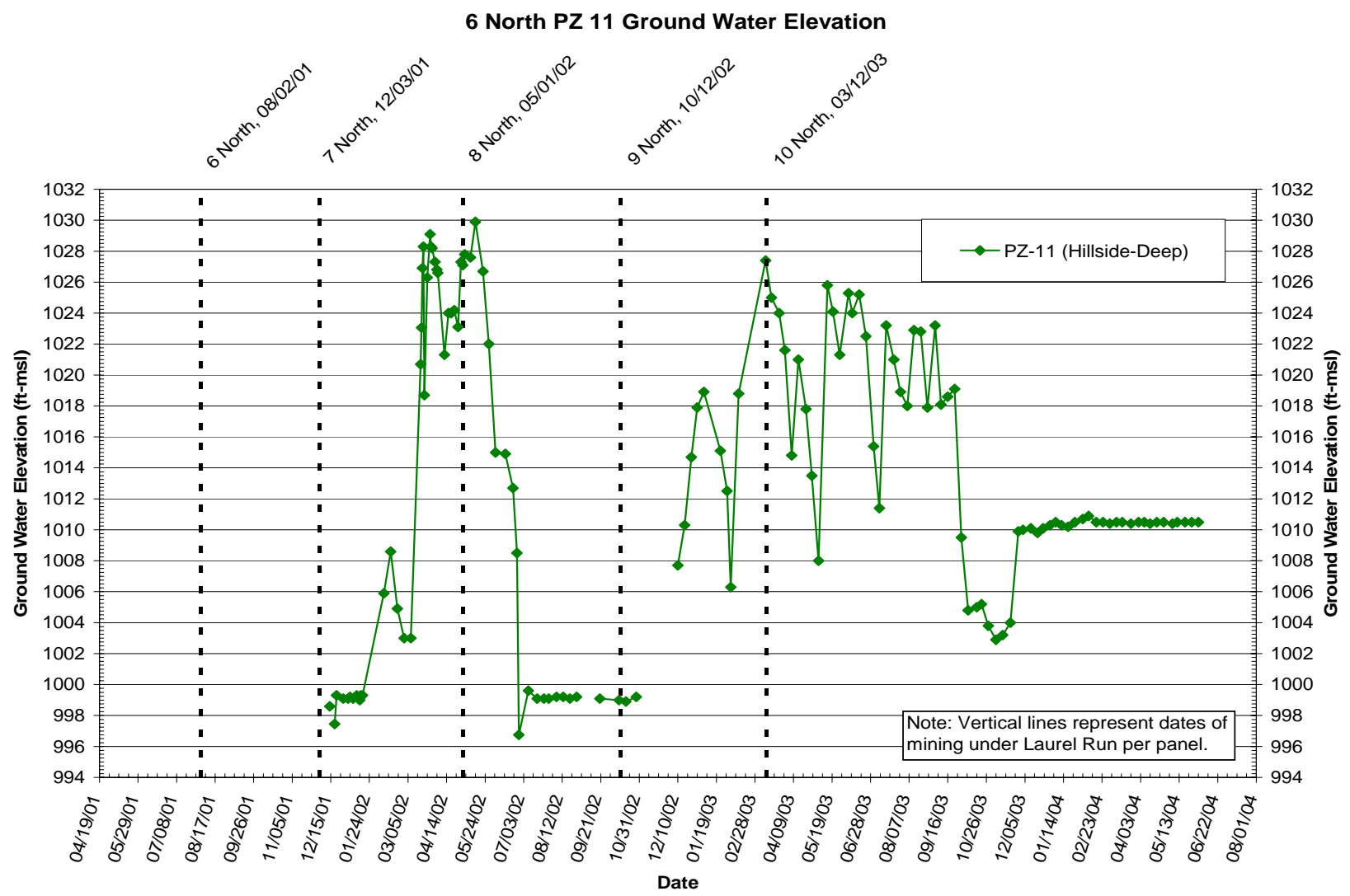

Figure 31 Groundwater elevation over time for PZ 11 of Site 5 


\subsubsection{Site 6 Data:}

\section{Monitoring Zones:}

Data for this site is from three wells. Two wells are located in the valley near the stream and one well is located on the hilltop.

PZ 12 was a shallow valley well with a casing depth of 22.3 feet from the surface, casing bottom elevation of 1,025.7 feet, and an interburden thickness of 385.5 feet from the aquifer to the Pittsburgh coal seam. The PZ 12 monitoring zone is located in 6 feet of the Waynesburg sandstone which has a thickness of 55.0 feet in this area.

PZ 13 was a deep valley well with a casing depth of 68.7 feet from the surface, casing bottom elevation of 979.3 feet, and an interburden thickness of 385.5 feet from the aquifer to the Pittsburgh coal seam. The PZ 13 monitoring zone is located in the Waynesburg sandstone.

PZ 25 was a deep hilltop well with a casing depth of 111 feet from the surface, a casing bottom elevation of 1,029 feet, and an interburden thickness of 385.5 feet from the aquifer to the Pittsburgh coal seam. This well is also monitoring the Waynesburg sandstone; however, the filter pack is only located in 1.5 feet of the aquifer.

\section{Groundwater Elevation Over Time:}

Figure 32 is a combined graph of all piezometer wells for this site located in the 7 North panel. Looking at Figure 32, the black vertical lines are representing the dates when the longwall face undermined the stream in each of the longwall panels. The pink, blue, and light blue lines represent $P Z 12,13$, and 25 groundwater elevation changes over time. This graph illustrates a time period from October 2001 to June 2004. Groundwater data collection began nearly a month before the 7 North panel undermined the site. 


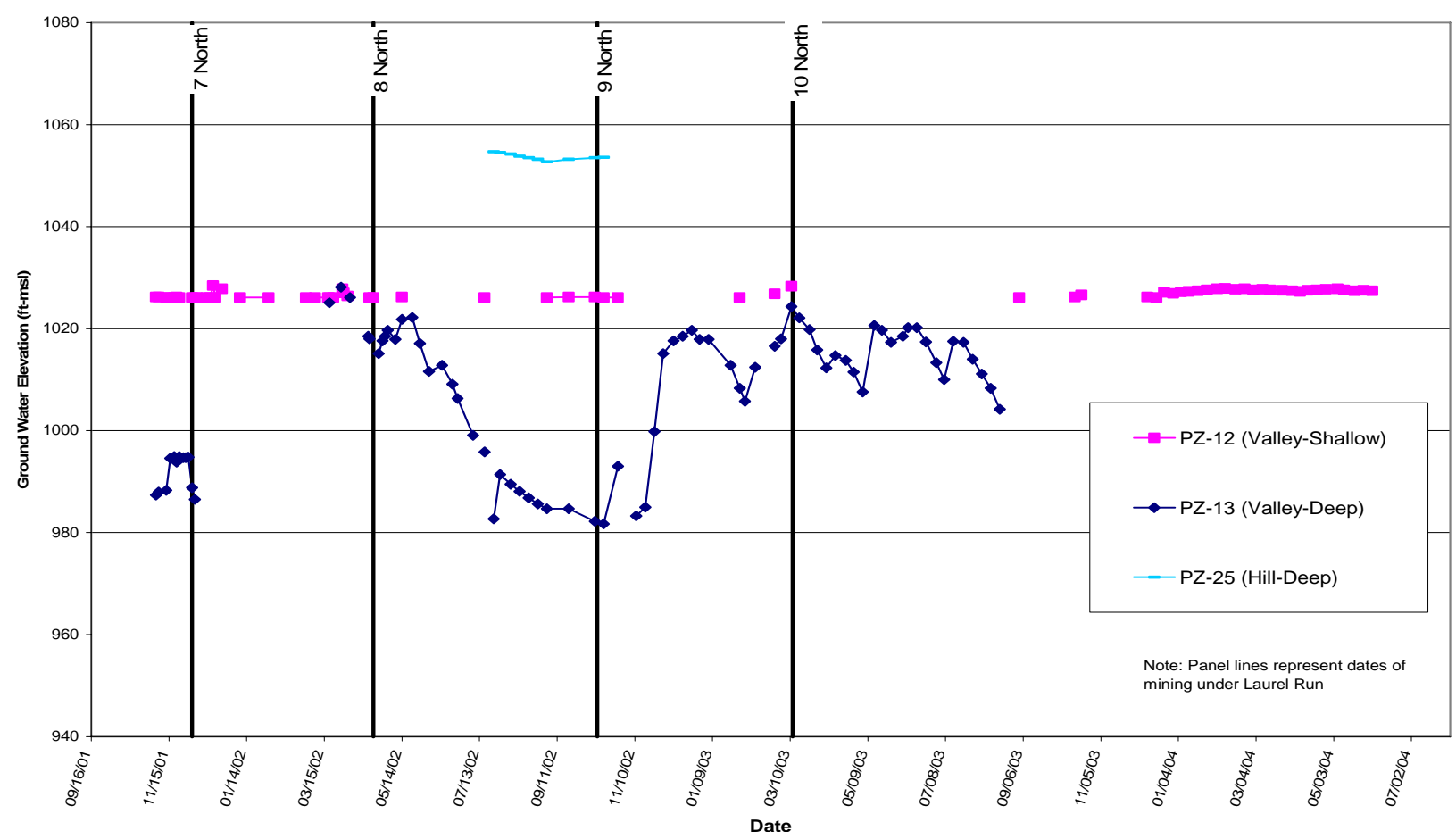

Figure 32 Combined groundwater elevation over time for site 6

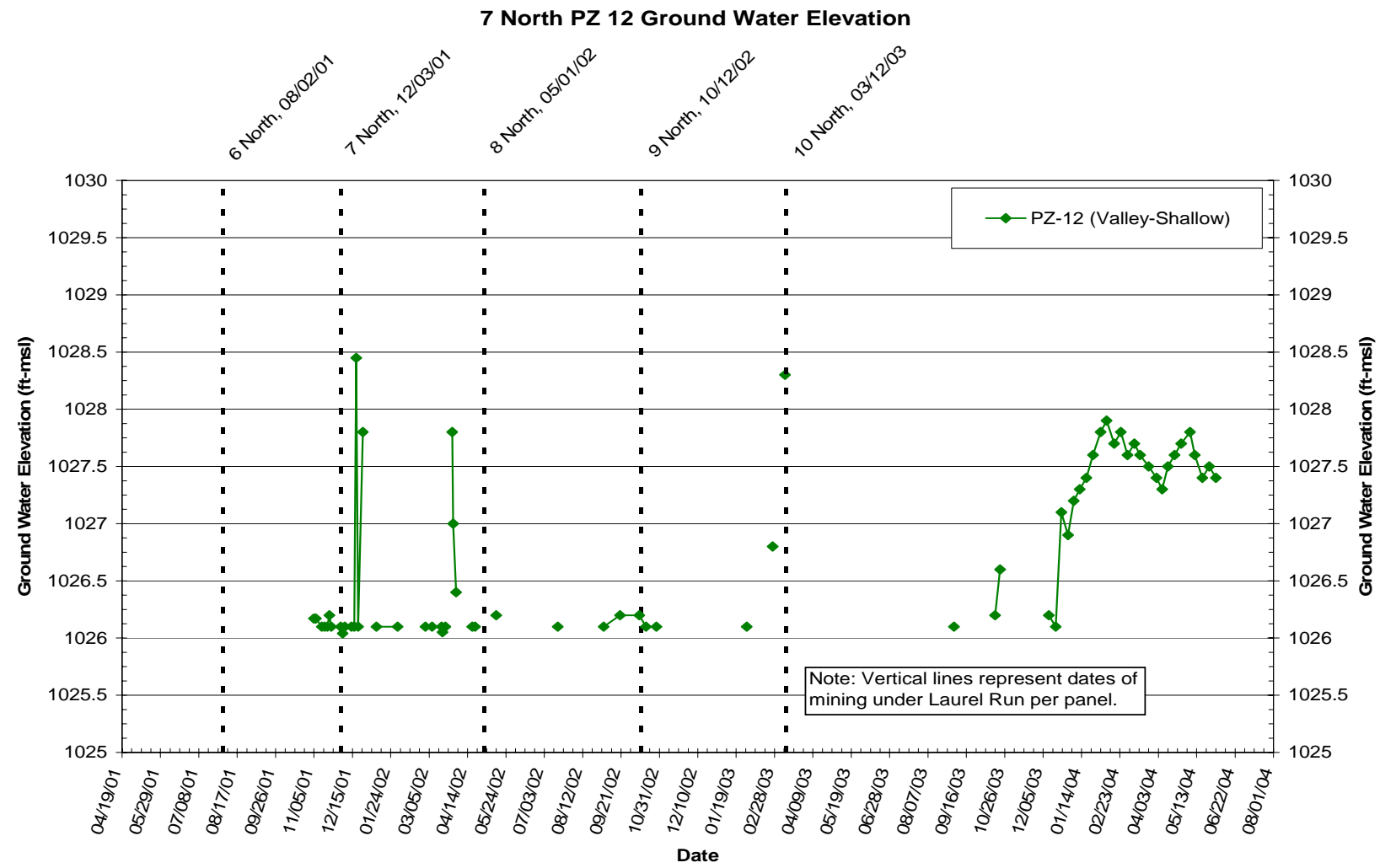

Figure 33 Groundwater elevation for PZ 12 of Site 6 
Taking a closer look at PZ 12, Figure 33 shows that PZ 12 groundwater elevation only changed 2.5 feet during the entire life of the well; ranging from an elevation of 1,026 feet to $1,028.5$ feet. Recalling that PZ 12 had a depth of 22.3 feet and an interburden thickness of 385.5 feet, the curve shown in Figure 33 provides the idea that this well was not affected by mining and also weather had little affect to the sandstone aquifer in the area. However, this well monitoring zone is located in the very top portion of the Waynesburg sandstone that is 55 feet thick.

Figure 34 shows the groundwater elevation of PZ 13 which is a deep valley well for Site 6. PZ 13 shows more activity than $P Z 12$ which is monitoring the same aquifer. The only difference between the two PZ wells is $P Z 13$ is monitoring the lower portion of the sandstone aquifer and will be under more pressure than PZ 12. PZ 13 shows a fluctuation range of 46 feet. The groundwater elevation for PZ 13 started at 995 feet prior to undermining by 7 North. This is not the actual premining groundwater elevation because the level would drop as the adjacent panel directly to the north was mined by Site 6 .

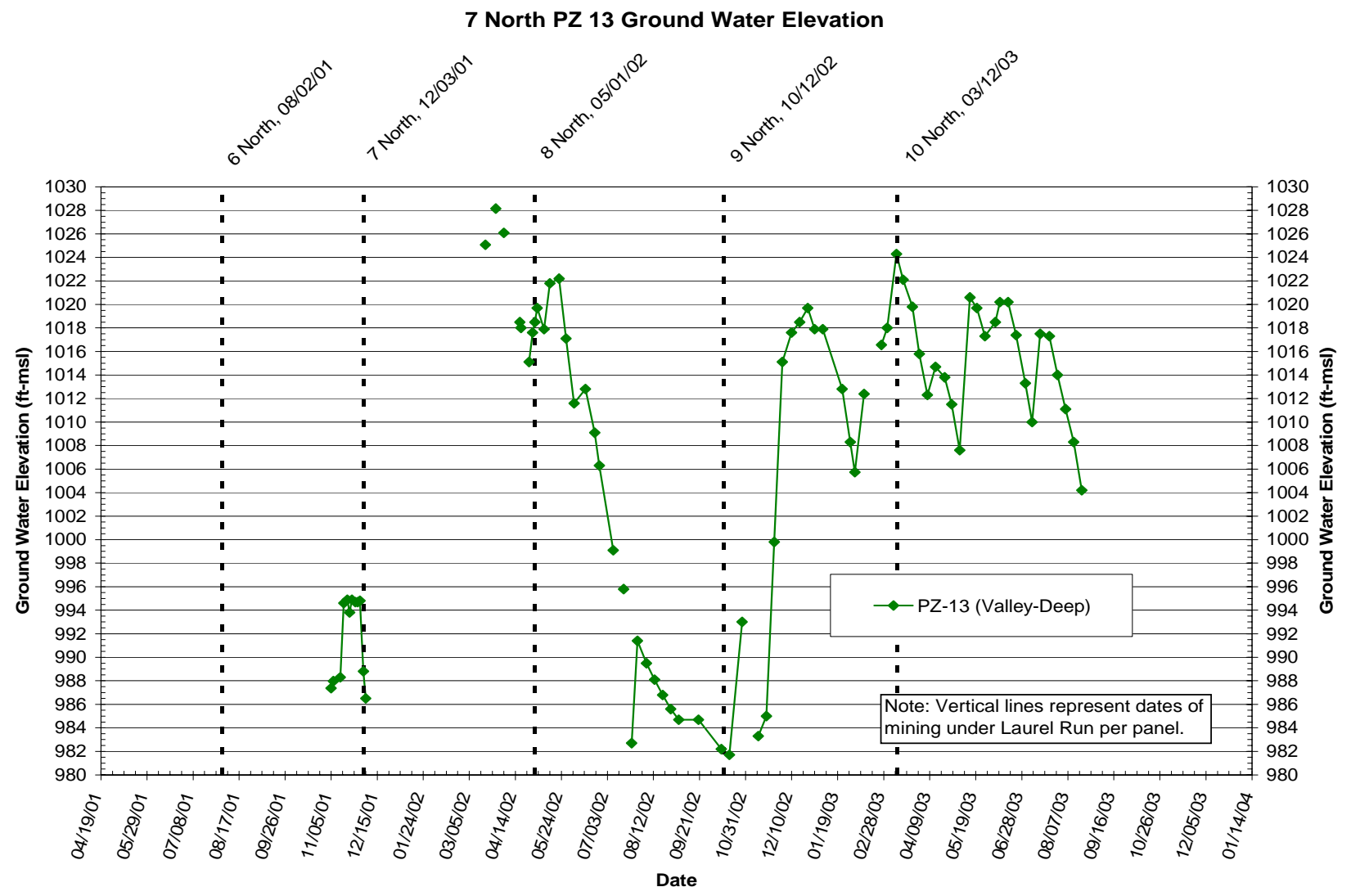

Figure 34 Groundwater elevation over time for PZ 13 of Site 6 
Looking at adjacent panel effects on the groundwater elevation, there is a slow but steady decline in elevation from an elevation of 1,022 feet to 982 feet over a four month period after the 8 North panel undermines next to Site 6 . This drop in elevation is magnified by weather effects because of a dry spell during these four months from June 2002 through October 2002.

The remainder of the PZ 13 curve from November 2002 through October 2003 illustrates close correlation with weather and stream flow data (Appendix 2).

PZ 25 is the deep hilltop well of Site 6 that only has 1.5 feet of the filter pack located within the top of the Waynesburg sandstone (Figure 35). This well data only contains few data points due to limited data recording, which lasted only 2.5 months starting at the end July in 2002. The small portion of data PZ 25 provided is not useful to determining the effects of groundwater elevation over time because of such a short data recording period.

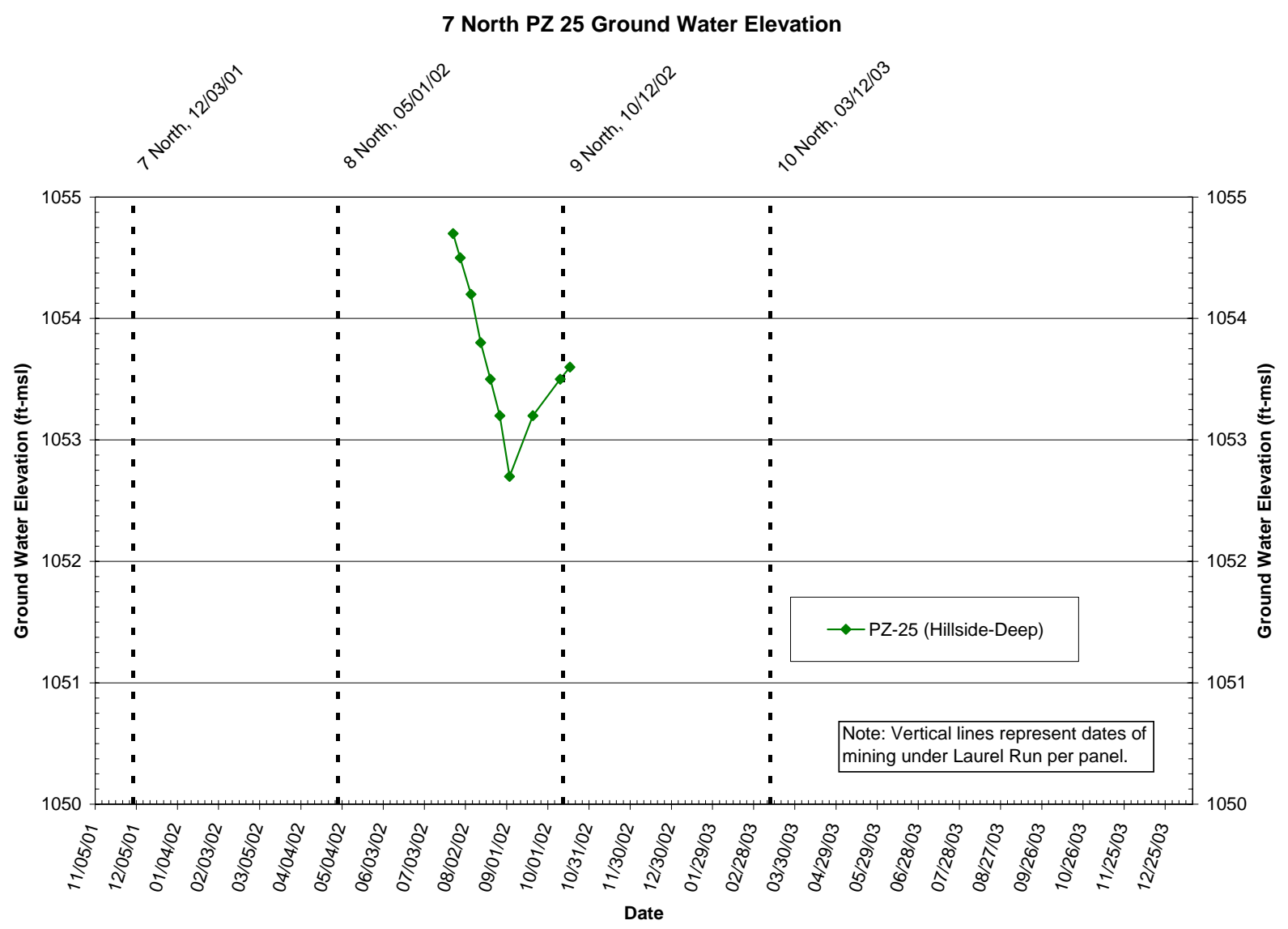

Figure 35 Groundwater elevation over time for PZ 25 of Site 6 


\subsubsection{Site 7 Data:}

\section{Monitoring Zones:}

Data for this site is from six wells; three wells are located in the valley near the stream and three wells are located on the hilltop.

PZ 14 was a shallow valley well with a casing depth of 20 feet from the surface, casing bottom elevation of 1,035 feet, and an interburden thickness of 411.8 feet from the aquifer to the Pittsburgh coal seam. The PZ 14 monitoring zone is located in 1.5 feet of the Calvin Run limestone where it is 4.7 feet thick.

PZ 15 was an intermediate valley well with a casing depth of 33 feet from the surface, casing bottom elevation of 1,022 feet, and an interburden thickness of 387.7 feet from the aquifer to the Pittsburgh coal seam. The PZ 15 monitoring zone is located in the upper 3.5 feet of the Waynesburg sandstone. The sandstone aquifer thickness for this area is 51 feet.

PZ 16 was a deep valley well with a casing depth of 60 feet from the surface, casing bottom elevation of 995 feet, and an interburden thickness of 387.7 feet from the aquifer to the Pittsburgh coal seam. PZ 15 and 16 were monitoring the same sandstone aquifer located in the Waynesburg sandstone.

PZ 17 was a shallow hillside well with a casing depth of 22.3 feet from the surface and a casing bottom elevation of 1,104.7 feet. This well does not have an interburden thickness because all of the filter pack was located in aquitards consisting of silt shale.

PZ 18 was an intermediate hillside well with a casing depth of 30.8 feet from the surface, a casing bottom elevation of 1,096.3 feet, and an interburden thickness of 461 feet from the aquifer to the Pittsburgh coal seam. PZ 18 was monitoring the Little Washington coal seam which is 0.6 feet thick and is surrounded by aquitards of silt shale and clay shale.

PZ 19 was a deep hillside well with a casing depth of 69 feet from the surface and a casing bottom elevation of 1,059 feet. This well does not have an interburden thickness because all of the filter pack was located in aquitards consisting of slit and clay shale. 
4 Groundwater Elevation Over Time:

Figure 36 is a combined graph of all piezometer wells for this site located in the 8 North panel. Looking Figure 36, the black vertical lines are representing the dates when the longwall face undermined the stream in each of the longwall panels. The blue, pink, red, light blue, purple, and brown lines represent PZ 14 through 19 groundwater elevation changes over time. This graph illustrates a time period from November 2001 to June 2004. Groundwater data collection began nearly five months before the 8 North panel undermined the site.

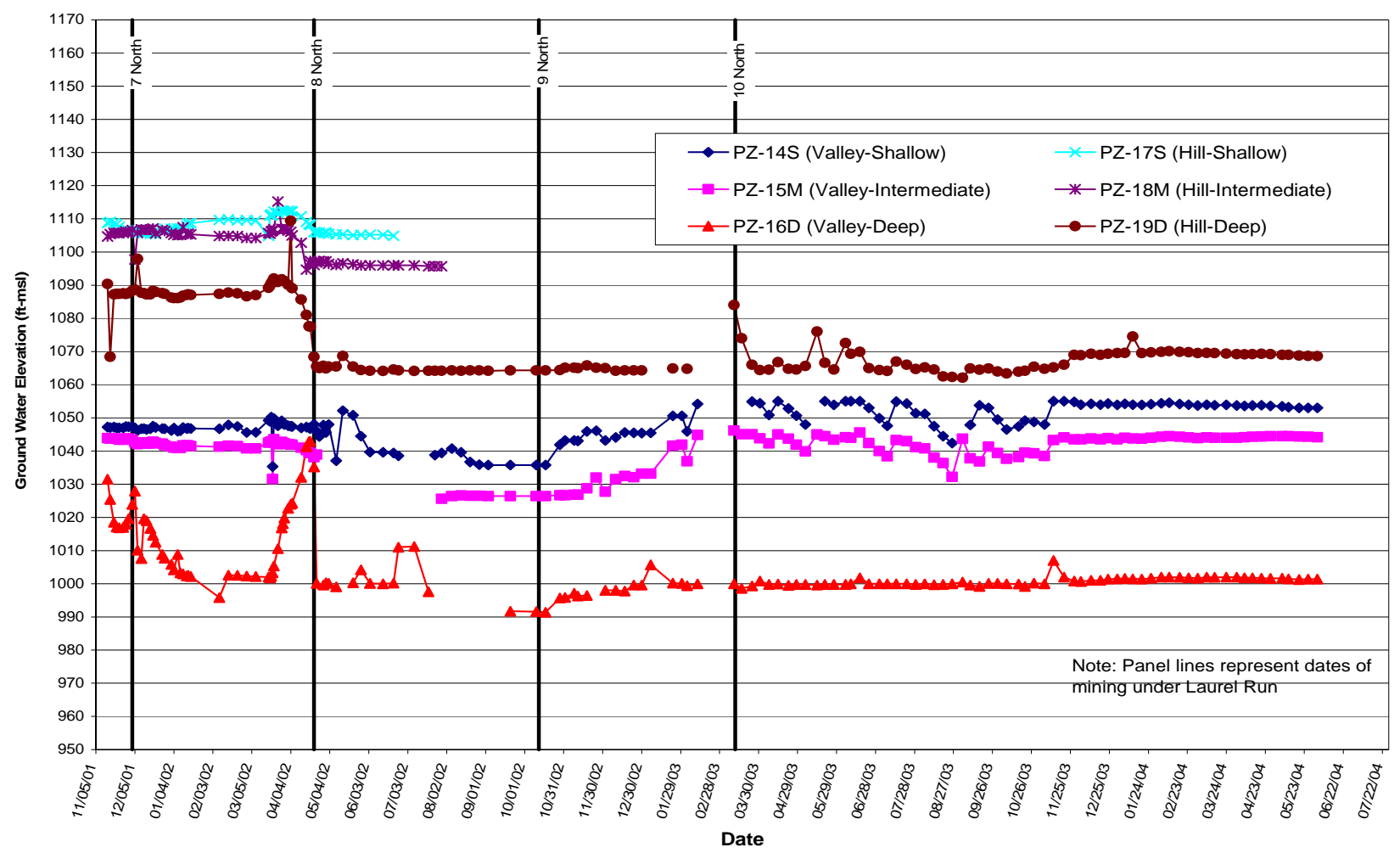

Figure 36 Combined groundwater elevation over time for Site 7

PZ 14 was the shallow valley well for Site 6. Looking at Figure 37, PZ 14 had a groundwater elevation of 1,045 prior to mining and absolute low of 1,040 feet post mining. Seven months after the well was undermined, PZ 14 had recovered to or up to 5 feet above the pre-mining groundwater level and completely stabilized above the stream elevation one year after undermining.

PZ 15 was the intermediate valley well with a depth of 33 feet, casing bottom elevation of 1,022 feet, and interburden thickness of 387 feet. Looking at Figure 
38, this well followed a similar trend to $P Z 14$, only differing from $P Z 14$ with a depth 13 feet deeper and a three month period of time where the well went dry just after mining. PZ 15 recovered to original levels 5 months after the well was undermined.

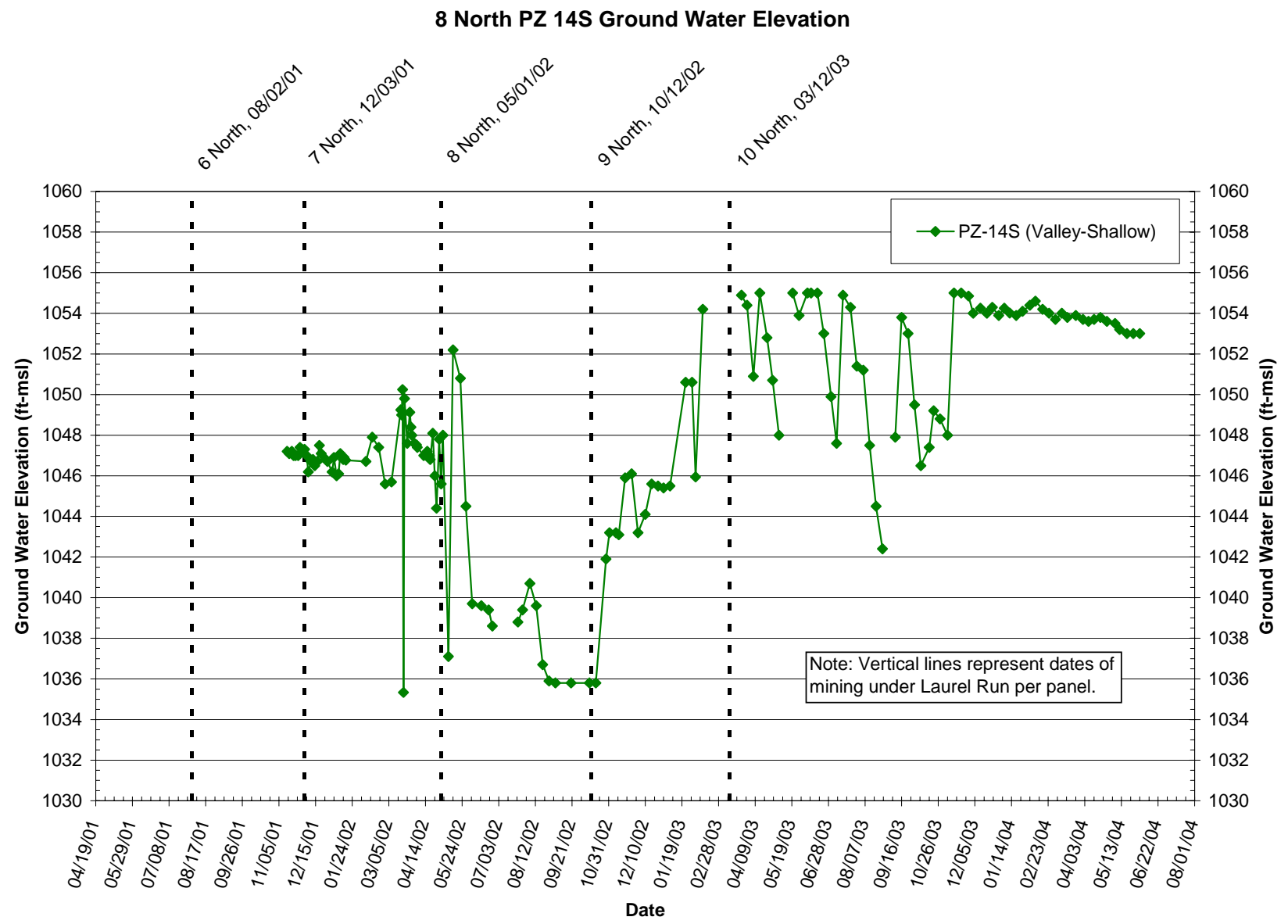

Figure 37 Groundwater elevation over time for PZ 14 of Site 7 


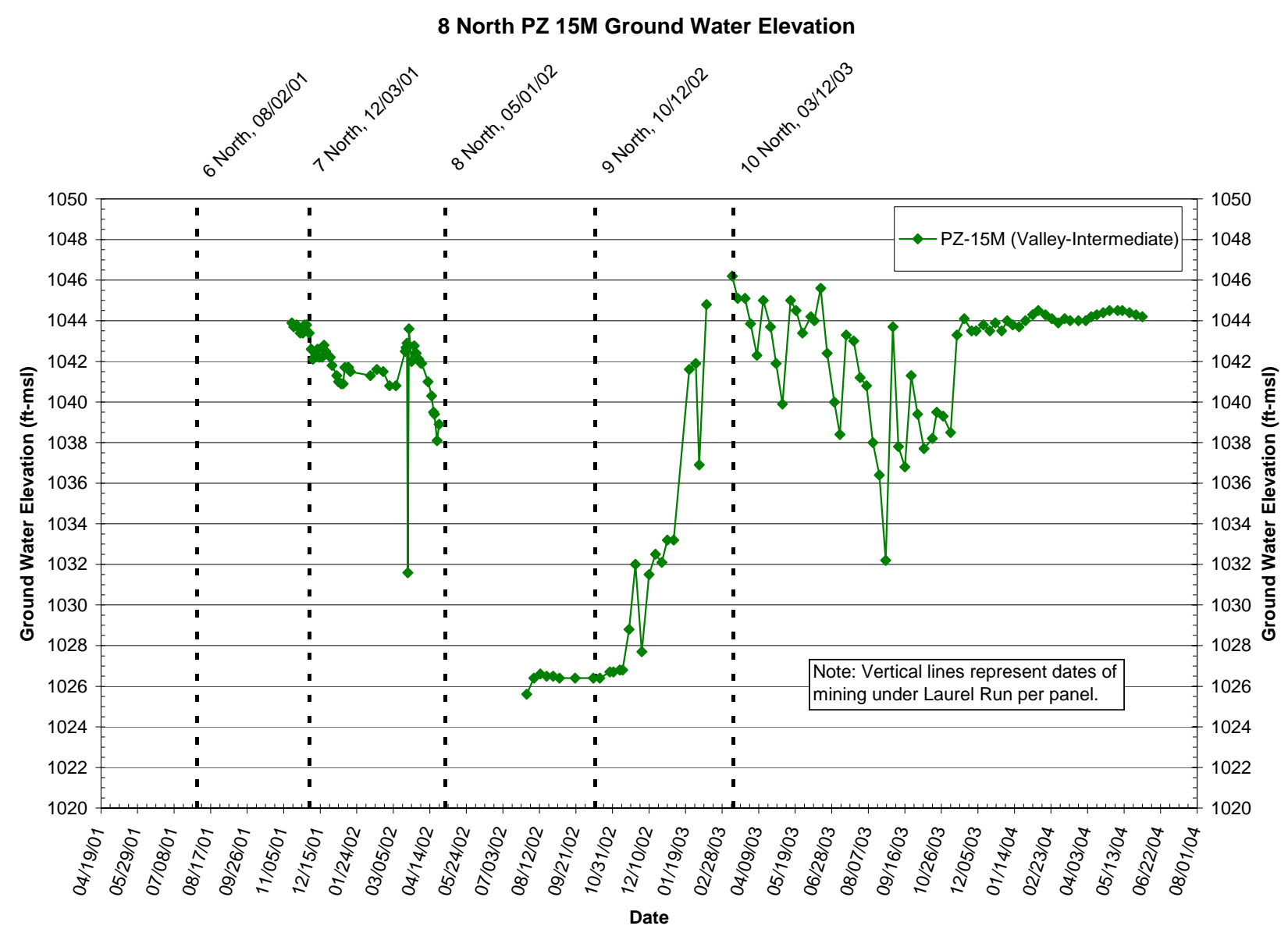

Figure 38 Groundwater elevation over time for PZ 15 of Site 7

In Figure 39, the PZ 16 original groundwater elevation prior to mining was unknown because it was affected by mining in the 7 North panel. This well was unique because the groundwater level for this well increased nearly 45 feet before mining. PZ 16 also normalized roughly 5 months after undermining the well.

PZ 17 was the shallowest hillside well of Site 7. Recalling that PZ 17 is located in aquitards, groundwater level decreased nearly 5 feet after undermining the well. Looking at Figure 40, PZ 17 remained stable for two months post mining before it went dry and did not return by May of 2004.

PZ 18 was the intermediate hillside well of Site 7 . Figure 41 shows that the PZ 18 well was affected similar to PZ 17. PZ 18 only differs from PZ 17 with a larger groundwater level change of 10 feet after undermining. PZ 18 is monitoring the Washington coal seam. 
PZ 19 was the deepest hillside well of Site 7. This well had an original groundwater elevation of 1,085 feet prior to mining. As PZ 19 was undermined, the water level increased slightly by 3 feet before decreasing by 43 feet after undermining. Looking at Figure 42, this well appeared to stabilize immediately after mining without increasing back toward the original groundwater elevation. PZ 19 was the only hillside well that did not go dry between June of 2002 and June of 2004.

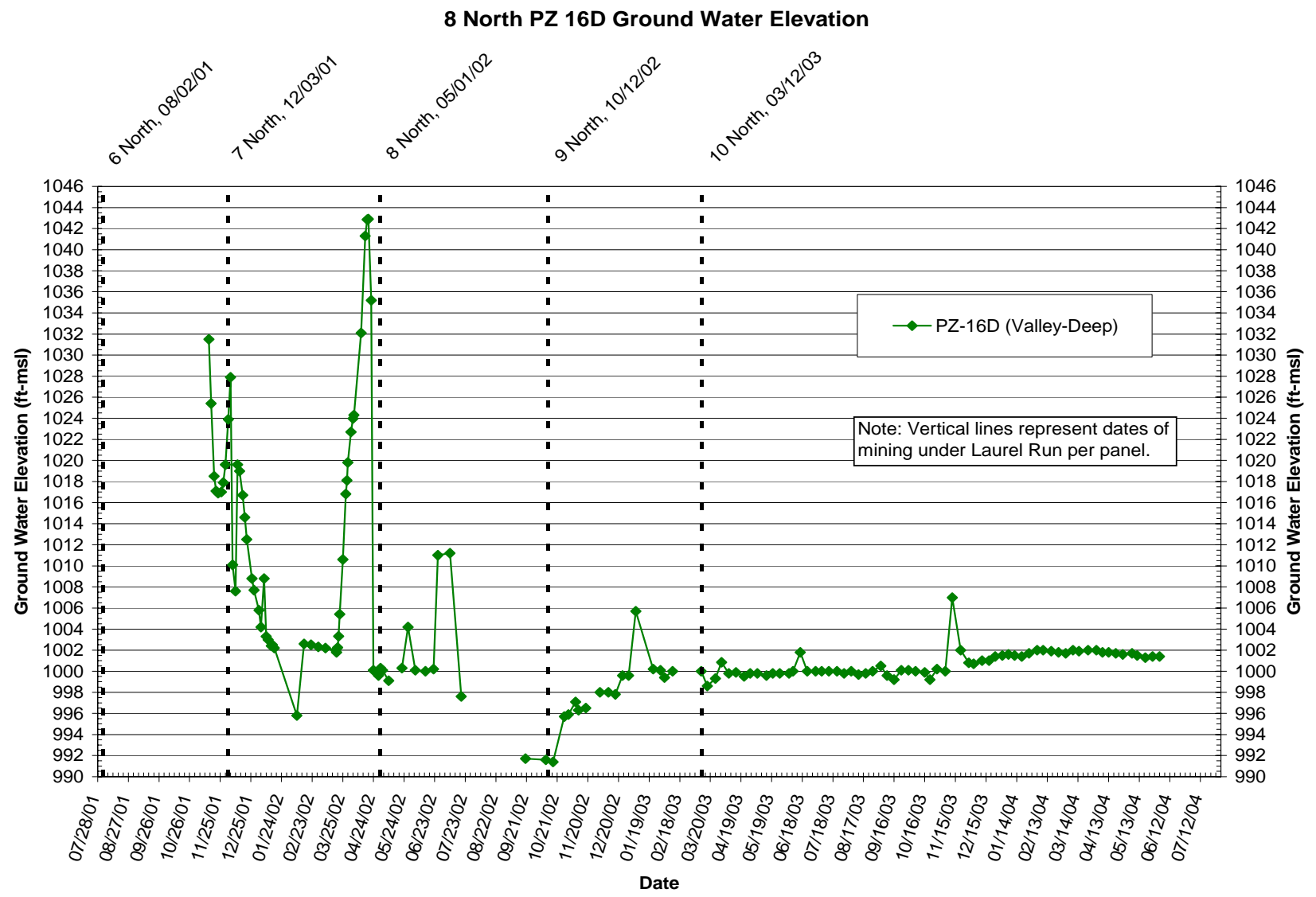

Figure 39 Groundwater elevation over time for PZ 16 of Site 7 


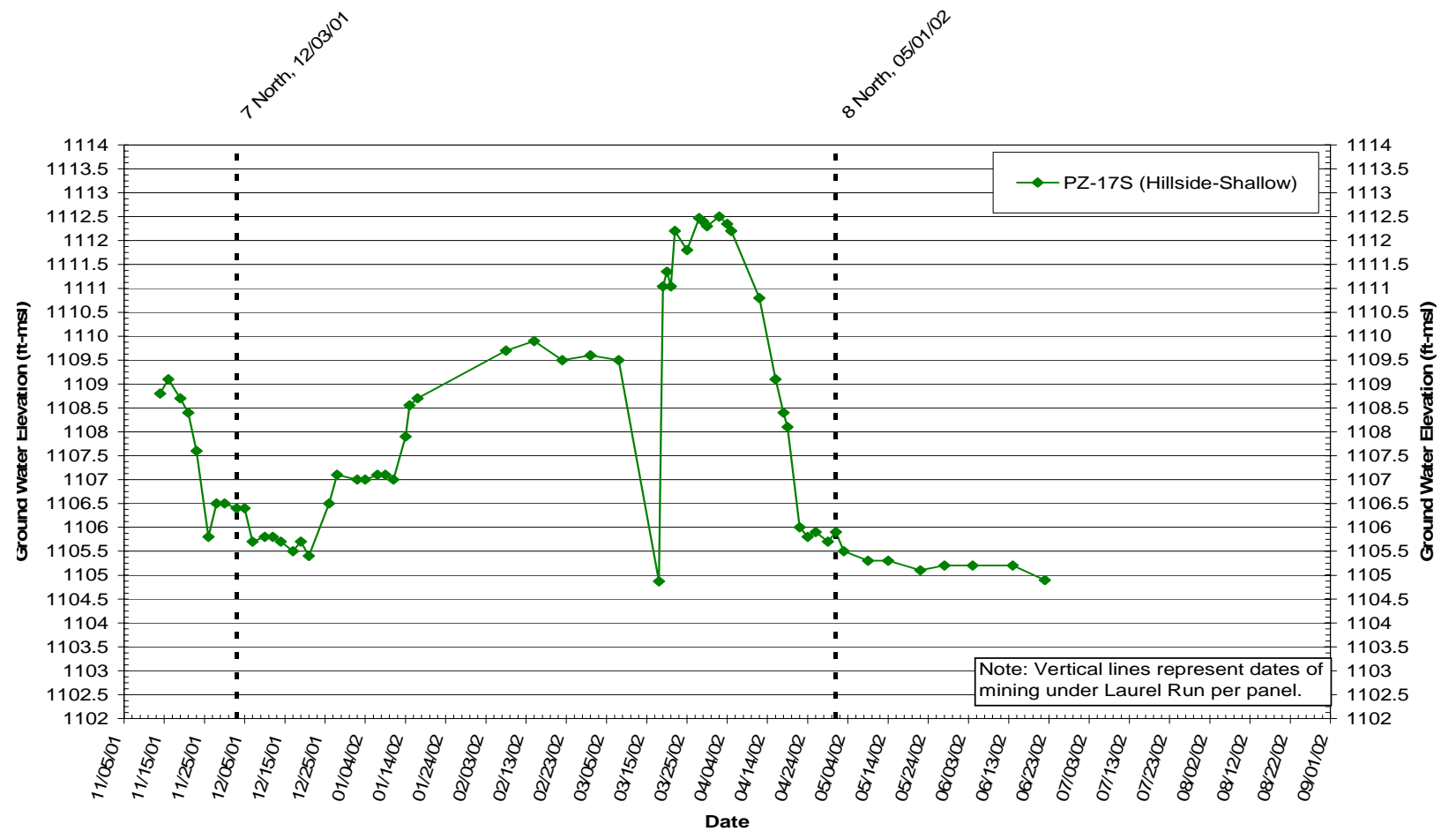

Figure 40 Groundwater elevation over time for PZ 17 of Site 7

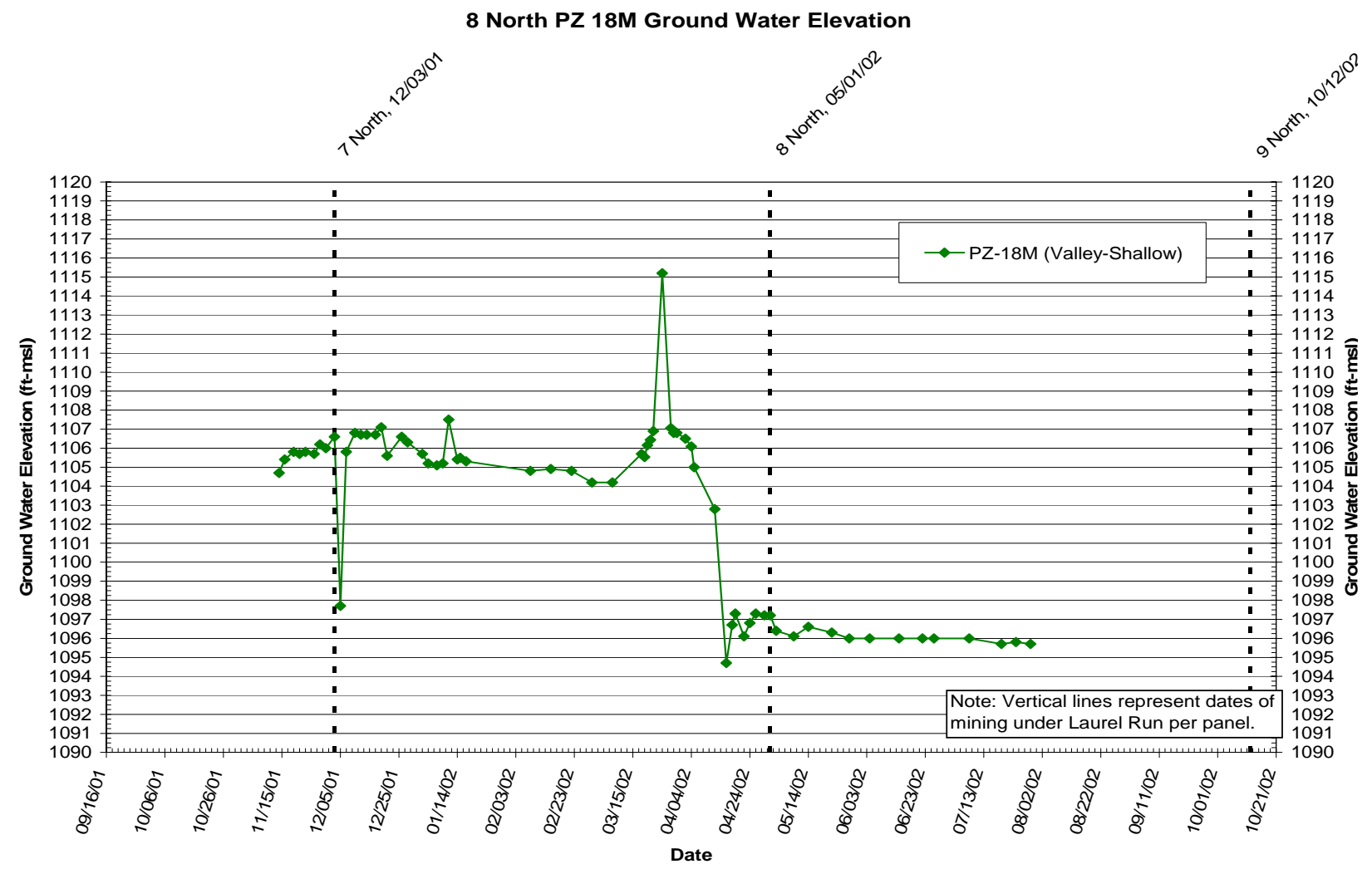

Figure 41 Groundwater elevation over time for PZ 18 of Site 7 


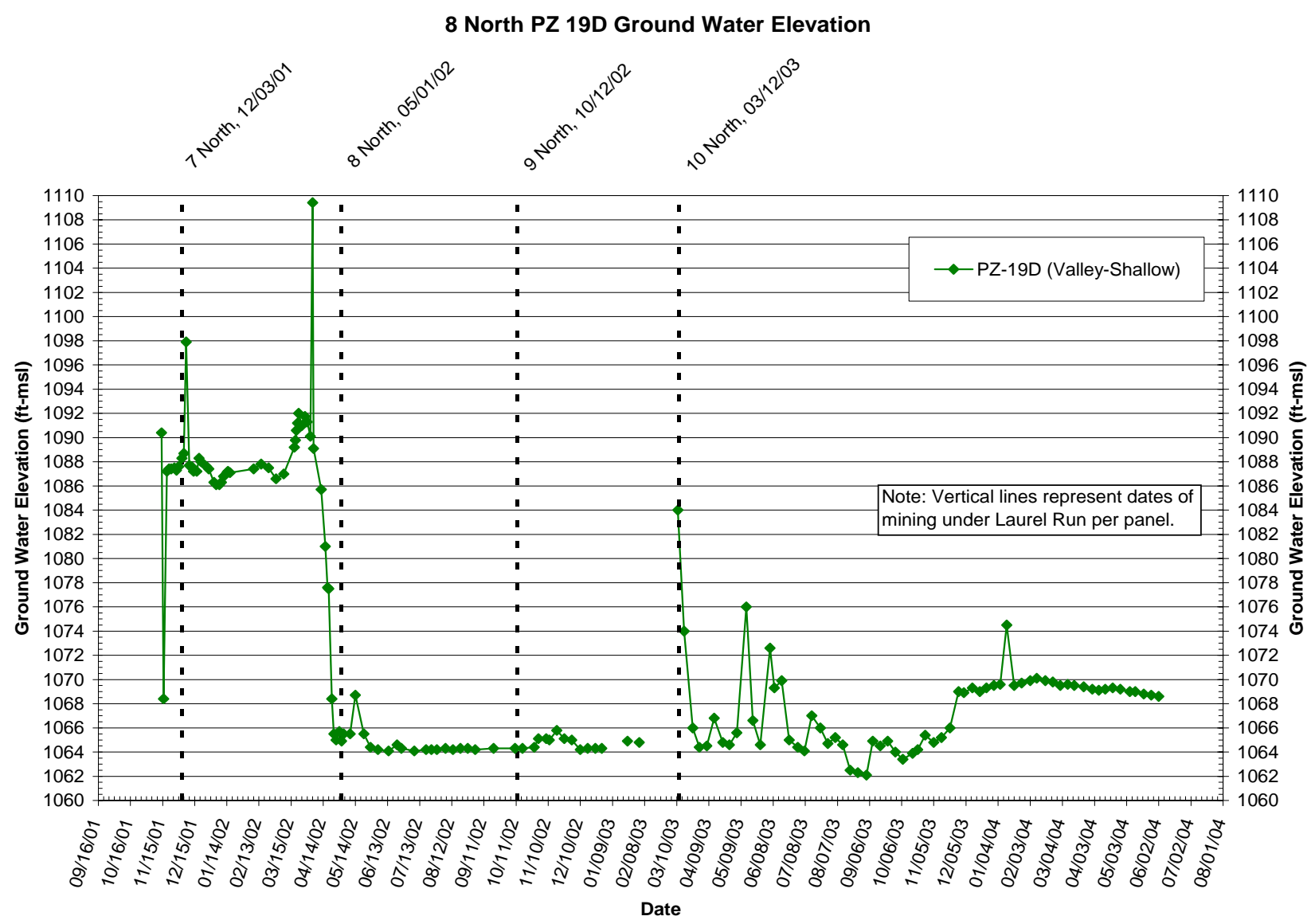

Figure 42 Groundwater elevation over time for PZ 19 of Site 7

\subsubsection{Site 8 Data:}

\section{Monitoring Zones:}

Data for this site is from four wells; two wells are located in the valley near the stream and two wells are located on the hilltop.

PZ 20 was a deep hillside well with a casing depth of 86 feet from the surface, casing bottom elevation of 1,044 feet, and an interburden thickness of 422 feet from the aquifer to the Pittsburgh coal seam. The PZ 20 monitoring zone is located in 9 feet of the Mannington sandstone where it is 11 feet thick.

PZ 21 was a shallow hillside well with a casing depth of 20 feet from the surface and a casing bottom elevation of 1,110 feet. The PZ 21 monitoring zone is located in two aquitards consisting of clay shale and gray clay stone.

PZ 22 was a deep valley well with a casing depth of 50 feet from the surface, casing bottom elevation of 1,030 feet, and an interburden thickness of 398 feet 
from the aquifer to the Pittsburgh coal seam. PZ 22 was monitoring the Waynesburg coal which has a thickness of 1.3 feet in the area. The Waynesburg coal is located between two aquitards of clay shale nature.

PZ 23 was a shallow valley well with a casing depth of 20 feet from the surface, a casing bottom elevation of 1060 feet, and an interburden thickness of 424.8 feet between the aquifer and the Pittsburgh coal seam. PZ 23 was monitoring the Mannington sandstone with the lower 1.5 feet portion of the filter pack located in the upper portion of the sandstone. The Mannington sandstone has a thickness of 11 feet in the Site 8 area.

\section{- Groundwater Elevation Over Time:}

Figure 43 is a combined graph of all piezometer wells for this site located in the 9 North panel. Looking Figure 43, the black vertical lines are representing the dates when the longwall face undermined the stream in each of the longwall panels. The light blue, blue, pink, and green lines represent PZ 20 through PZ 23 groundwater elevation changes over time. This hydrograph illustrates a time period from November 2001 to June 2004. Groundwater data collection began nearly one year before the 9 North panel undermined the site.

Panel 9 Piezometers Original Data Plot

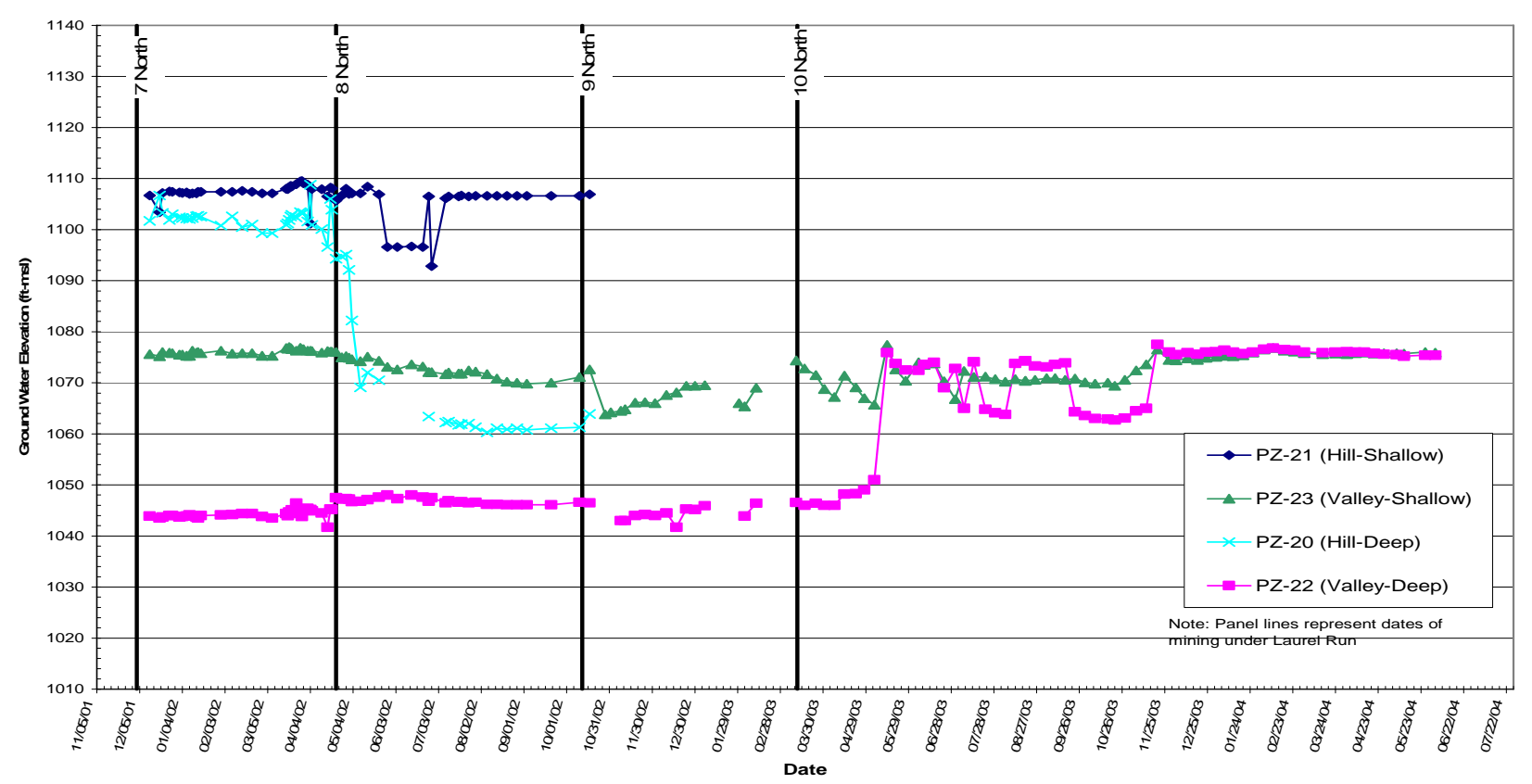

Figure 43 Combined groundwater elevation over time for Site 8 
In Figure 44, PZ 20 groundwater elevation prior to mining was approximately 1,100 feet before decreasing substantially to an elevation of 1,060 when the adjacent panel to the north moved through the area. The water level then remains constant without any sign of recharge until the well is undermined by the 9 North panel. The data collection then stops because the well goes dry and never returns through the life of the well. This shows that the water located in the Mannington sandstone is displaced and does not recharge a few months after undermining. PZ 20 was unique because the groundwater level for this well shows a mining related effect without any noticeable spikes in the data that would be weather related.

PZ 21 was the shallowest hillside well of Site 8. Figure 45 shows a closer view of the PZ 21 data. Recalling that this piezometer is located in aquitards, the data does not appear to correlate with weather effects and shows very little mining related changes in groundwater elevation. The only noticeable change in Figure 45 is the water level drops from 1,107 feet to 1,097 feet four months before the longwall face arrived at the site location. The initial drop started in June of 2002, and the water level sharply rebounded in July of 2002. This rebound took place 3.5 months before the longwall undermined PZ 21, and it showed no effects as the face arrived. The data collection ended on 10-21-02; ten days after the longwall undermined the site.

PZ 22 was the deep hillside well of Site 8. Figure 46 shows that PZ 22 was affected by mining nearly 2 panels away and it continued until mining stopped in the 10 North panel. The water level remained relatively steady from the beginning of 2002 until May of 2003 in that the ground water level only fluctuated 6 feet; from an elevation of 1,042 feet to 1,050 . As soon as mining stopped in the 10 North panel, the groundwater elevation made a dramatic increase to 1,074 feet in May of 2003. From May of 2003 till July of 2004 the groundwater elevation trend followed the precipitation and stream flow data shown in Error! Reference source not found.. The well stabilized at an elevation of 1,076 feet.

PZ 23 was the shallow hillside well of Site 7 that monitors the Mannington sandstone (Figure 47). This well had an original groundwater elevation of 1,076 
feet prior to mining 8 North when it began slowly dropping to 1,070 feet just before 9 North undermined the Site. As PZ 23 was undermined, the water level increased slightly by 2 feet before decreasing by 10 feet after undermining the 9 North panel. After the 10 North panel mined adjacent to the mine site, PZ 23 began to fluctuate along with the weather patterns for a period of 8 months before the groundwater elevation stabilized at the same level as the pre-mining elevation. This well appeared to stabilize immediately after mining without increasing back toward the original groundwater elevation. This well illustrated both the affect of mining (1 panel prior to and after 9 North) and the weather effects.

\section{North PZ 20 Ground Water Elevation}

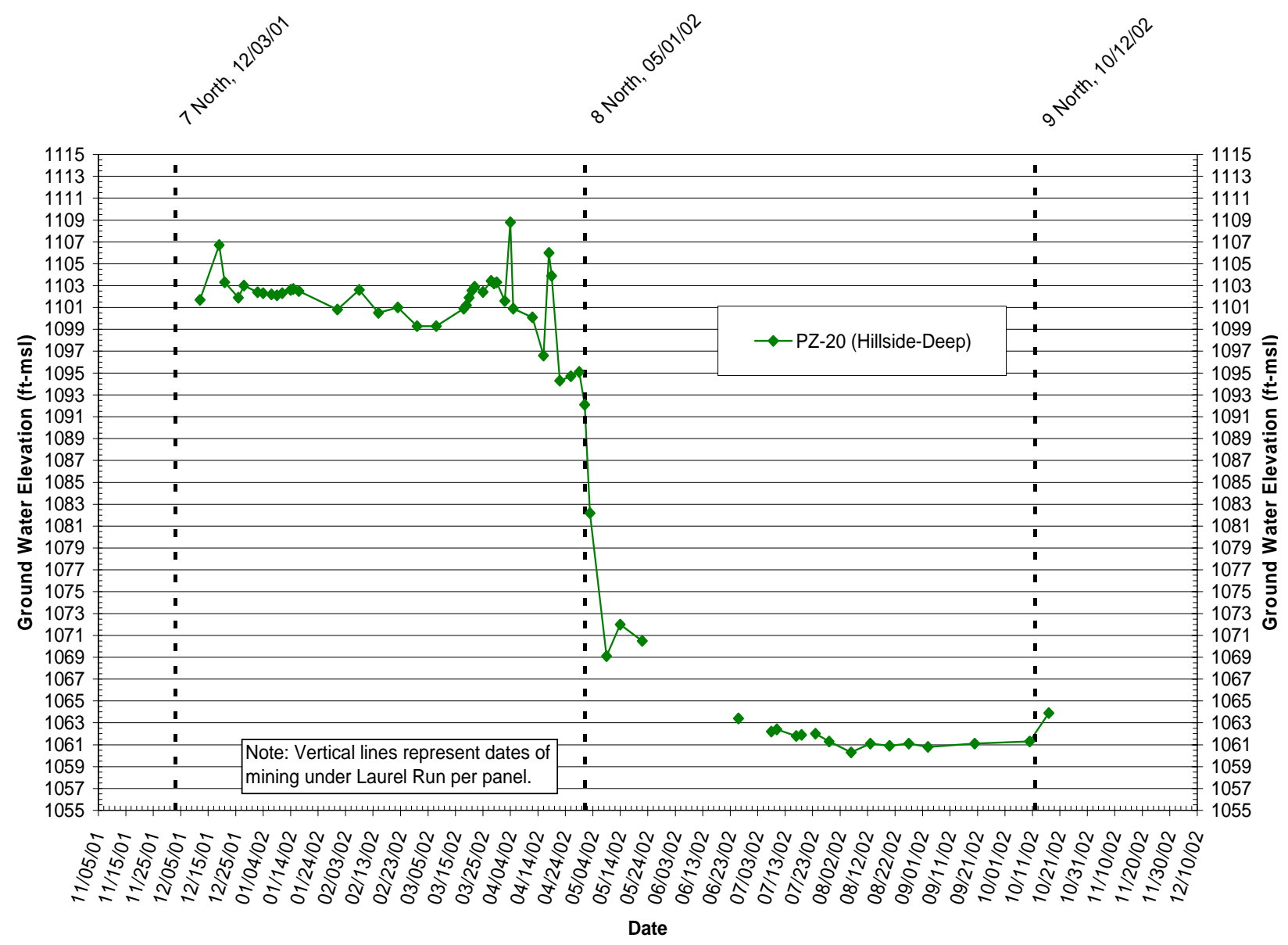

Figure 44 Groundwater elevation over time for PZ 20 of Site 8 


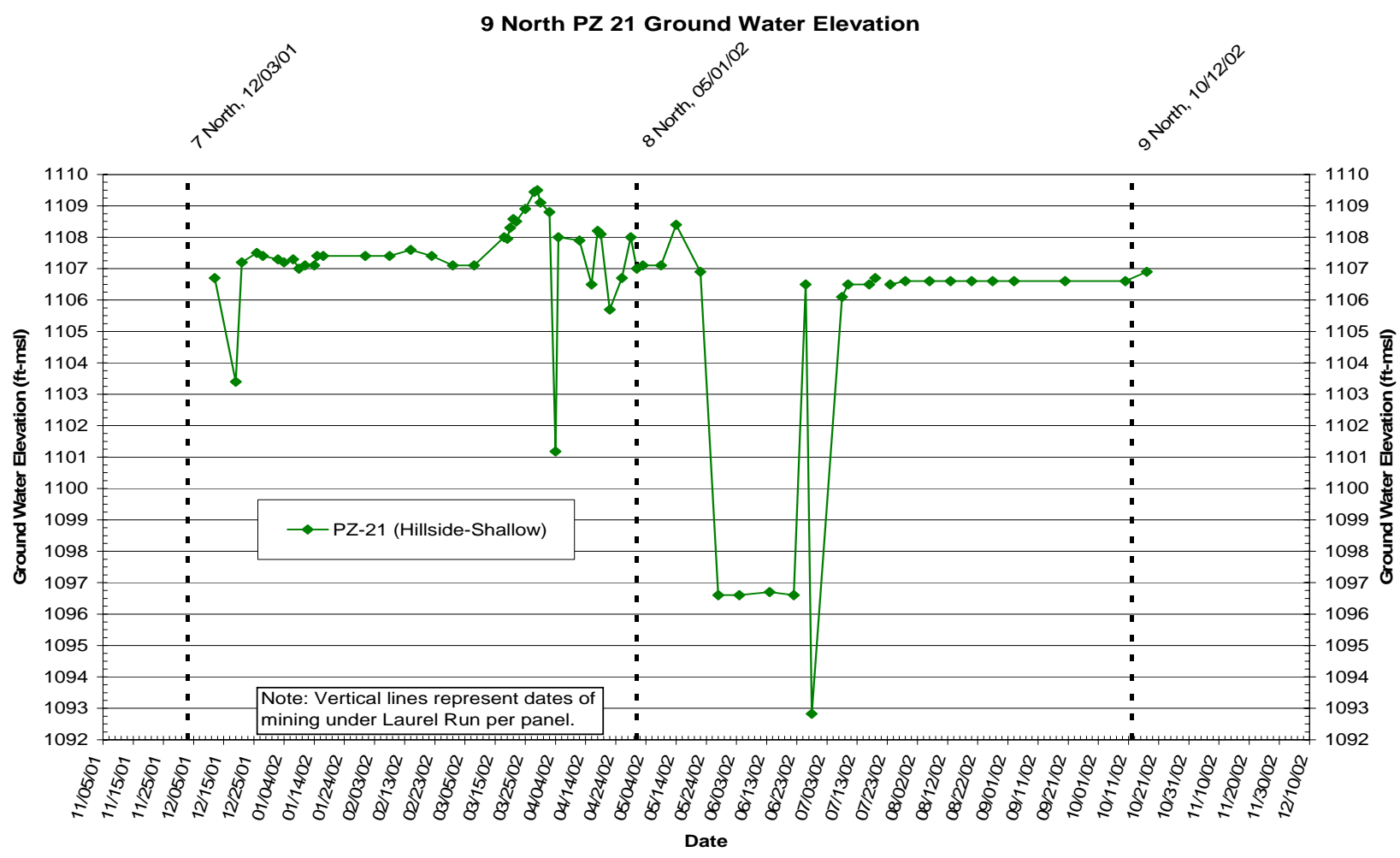

Figure 45 Groundwater elevation over time for PZ 21 of Site 8

\section{North PZ 22 Ground Water Elevation}

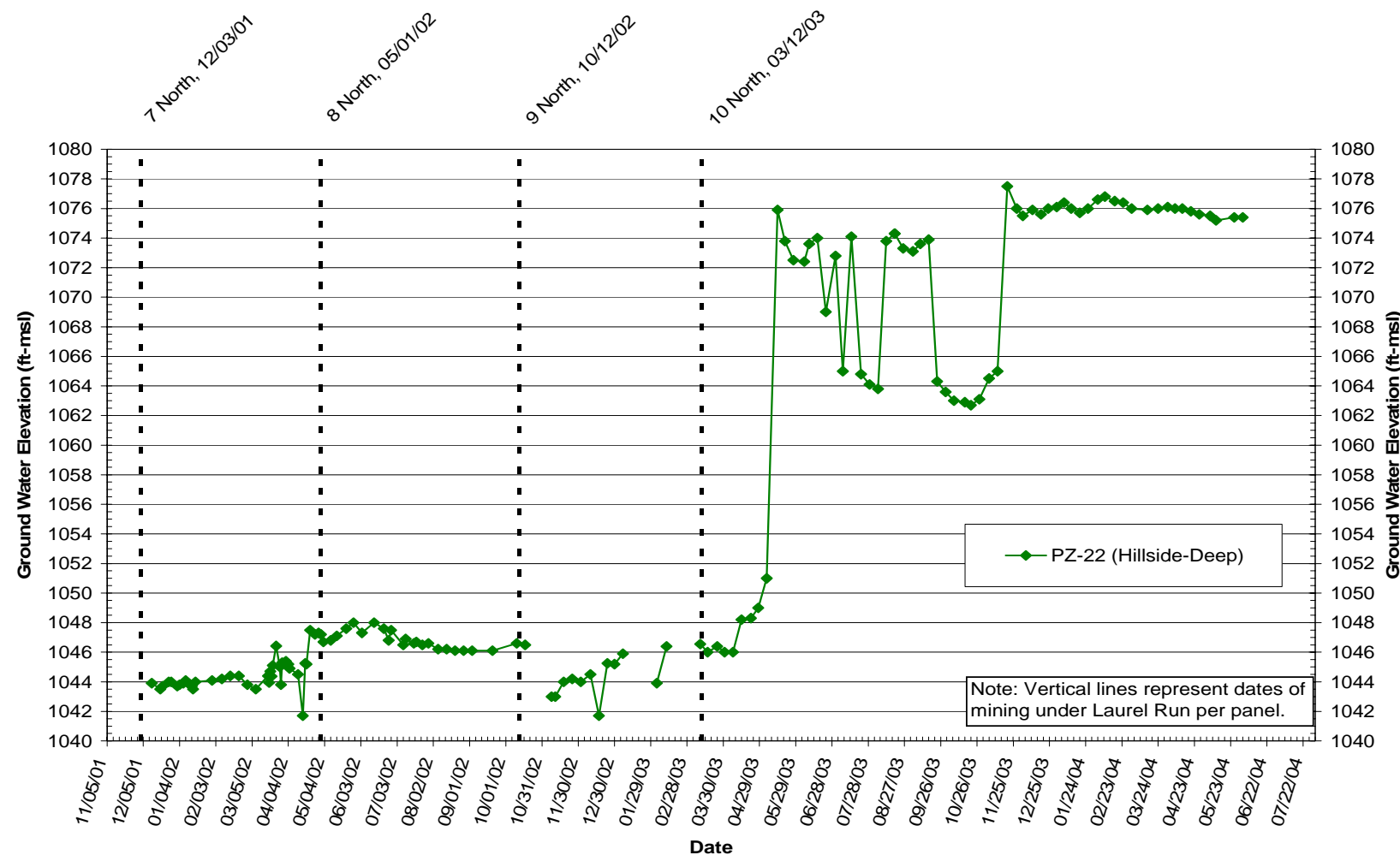

Figure 46 Groundwater elevation over time for PZ 22 of Site 8 


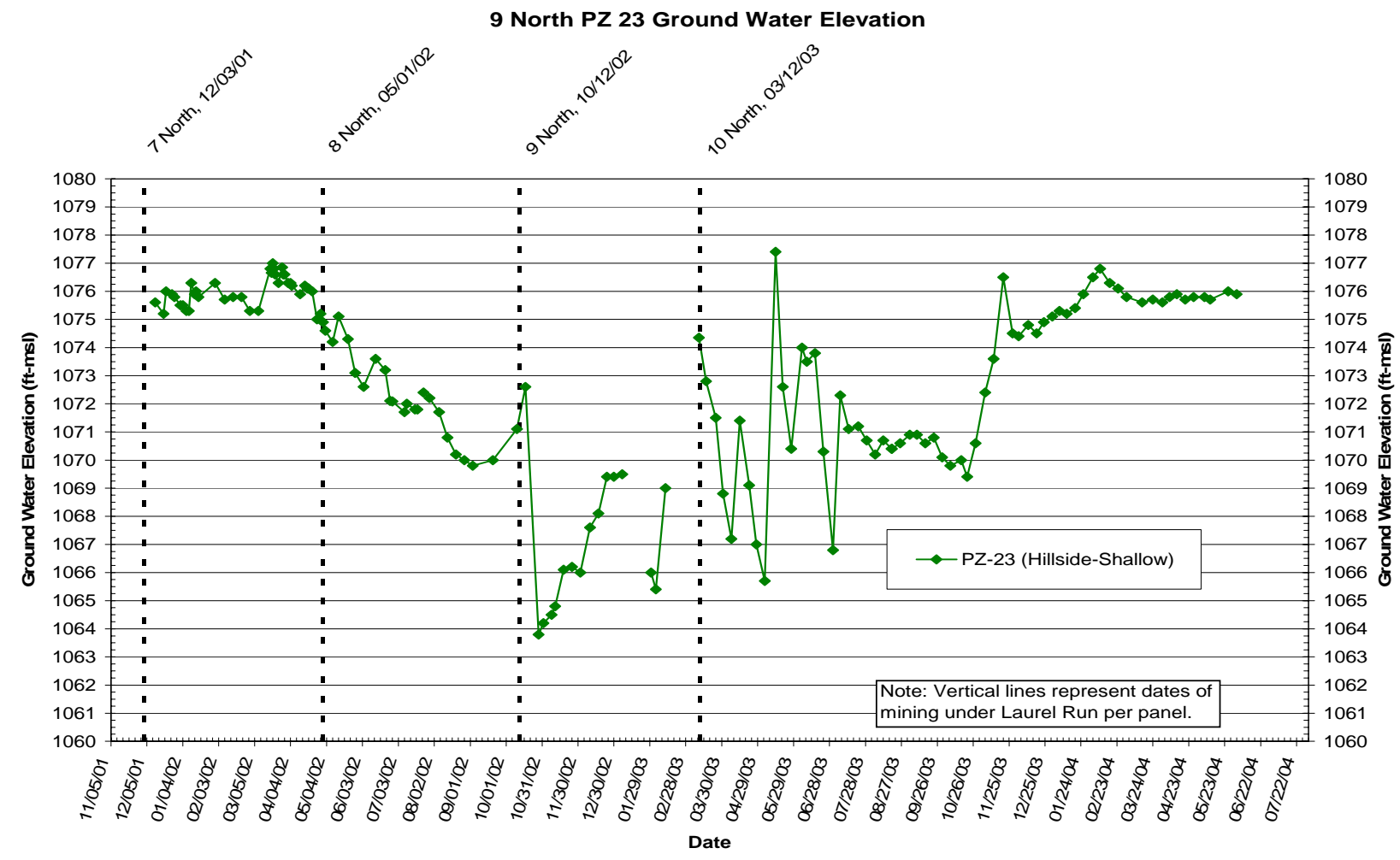

Figure 47 Groundwater elevation over time for PZ 23 of Site 8 


\subsection{Longwall Mining Affect on Hydrographs of Water Wells}

\subsubsection{Aquifer versus Aquitards - General}

There were several potential aquifer strata in the studied site; Sewickley Sandstone, Uniontown Limestone, Waynesburg Sandstone, Waynesburg Limestone, Waynesburg Coal, and Mannington Sandstone. Among them, Uniontown Limestone, Waynesburg Sandstone, and Sewickley Sandstone were, in descending order, major aquifers.

\subsubsection{Aquifer Strata}

\section{Sewickley Sandstone}

Sewickley Sandstone extended from Panel 1 North to and ended in Panel 4 North. It was more than $20 \mathrm{ft}$ thick in the northern end of Panel 1 North and getting thinner toward the south. In Panel 4 North where the piezometer clusters PZ 4-8 were located it was only about $2 \mathrm{ft}$ thick. It was 107-118 ft above the Pittsburgh Seam. There were two wells monitored water heads in the Sewickley sandstone, PZ 3 and 6.

\section{1. $P Z 3$ in Panel 1}

The monitored zone was located completely in the sandstone, the bottom of which was $107 \mathrm{ft}$ from the Pittsburgh seam top. So after longwall mining, the Sewickley sandstone was completely fractured. (Note the ratio of interburden thickness to mining height $=107 \mathrm{ft} / 7 \mathrm{ft}=15)$. So when Panel 1 was undermined, water was completely lost. Also since the Sewickley sandstone extended from Panel 1 through panel 3 to and ended in Panel 4, when Panel 3 was mined, (note Panel 1 was mined after panel 3.) the Sewickley sandstone was also broken, causing the well head to drop approximately $25 \mathrm{ft}$ immediately, even though it was located more than 1,000 ft (one panel width) away.

\section{PZ6 in Panel 4}


The monitored zone consisted of approximately, in ascending order, $<1 \mathrm{ft}$ clay shale, $2 \mathrm{ft}$ of Sewickley sandstone, and $>9 \mathrm{ft}$ of silty shale with sandstone streaks. Since silty shale and clay shale are not known to be an aquifer, water in this well was most likely supplied by the Sewickley sandstone. Again, after mining of Panel 3, clay shale, Sewickley sandstone, and silty shale were all broken because they were also located in the fractured zone. Because the ratio of interburden thickness to mining height was, at the bottom of the monitored zone $=118 \mathrm{ft} / 7 \mathrm{ft}=17$, and at the top of the monitored zone $=130 \mathrm{ft} / 7 \mathrm{ft}=19$. When panel 3, the edge of which was approximately $600 \mathrm{ft}$ away, was mined, water head dropped quickly, because Sewickley sandstone was broken above Panel 3 and drained water off this well. Unfortunately, this well was destroyed before Panel 1 and Panel 4 (in panel) were mined.

\subsubsection{Uniontown Limestone}

Uniontown limestone was very thick, approximately 100-122 ft thick, and was about $230-240 \mathrm{ft}$ above the Pittsburgh seam. It extended un-interruptedly from Panel 1 North in the north all the way to Panel 10 in the south. It was massive in the north, but was inter-bedded with silty shale and clay shale in, and the number of inter-bedding increasing toward, the south. There were two wells monitoring water heads in Uniontown limestone, PZ 2 and 5.

\section{1. $P Z 2$ in Panel 1}

PZ 2 in Panel 1 was located $240 \mathrm{ft}$ above the Pittsburgh Seam, and thus in the mid portion of the fractured zone. When Panel 1 was mined first about 1,000 $\mathrm{ft}$ to the south, its water head dropped slowly about $12 \mathrm{ft}$, then rose slowly to premining level right before, and dropped more than $100 \mathrm{ft}$ quickly during, in-panel (Panel 1) mining. It then rose $80 \mathrm{ft}$ slowly, but began to drop sometime before Panel 4 mining, 2,200 ft to the south. It continued to drop, but recovered before Panel 5 mining. It dropped slowly after Panel 5 mining. Water head drop 
continued even after Panel 6 mining, 4,670 ft to the south. This indicated water flow connection in the Uniontown Limestone within almost one mile.

\section{PZ 5 in Panel 4}

The monitored zone, about $232 \mathrm{ft}$ above the Pittsburgh seam, was also located entirely in the Uniontown Limestone, the bottom of which was about 135 $\mathrm{ft}$ above the Pittsburgh seam. Therefore, the entire Uniontown Limestone was located within the fractured zone after panel 4 was mined, though the monitored zone was in the upper portion of the fractured zone. Because the ratio of interburden thickness to mining height $=232 \mathrm{ft} / 7 \mathrm{ft}=33$.

When Panel 3, $500 \mathrm{ft}$ to the north, was mined, water dropped $80 \mathrm{ft}$ quickly and then rose $10 \mathrm{ft}$ and held steady until Panel 1, 2,000 ft to the north, was mined. Unfortunately, there were no data points between Panel 1 and Panel 4 mining. During Panel 4 mining, the water head dropped $43 \mathrm{ft}$ very quickly and then rose continuously until Panel 5 mining, $600 \mathrm{ft}$ to the south, causing $8 \mathrm{ft}$ water head drop. Unfortunately, monitoring stopped after Panel 6 mining.

Similar to PZ 2 in Panel 1, water head drop was most severe during inpanel mining (Panel 4). But soon rose to more than $60 \mathrm{ft}$ above the pre-mining level. Water head continued to rise before, during, and after Panel 5 mining. It dropped after Panel 6 mining. Unfortunately, the well was terminated after Panel 6 mining.

\subsubsection{Waynesburg Sandstone}

Waynesburg Sandstone was a consistent member of aquifer strata all across the 9- panel section. It was very shallow in the north where valley bottoms and hillsides prevailed and deeper in the south where panels were under the hill tops. Its thickness ranged from $10 \mathrm{ft}$ in the north to $57 \mathrm{ft}$ in the south. Since its bottom was $330-355 \mathrm{ft}$ above the Pittsburgh seam, it was in the very top portion of the fractured zone generated by a 7 -ft longwall mining underneath, 
because the ratio of interburden thickness to mining height $=330 \mathrm{ft} / 7 \mathrm{ft}-355 \mathrm{ft} / 7$ $\mathrm{ft}=47-51$.

There were 13 water wells that monitored water head in Waynesburg Sandstone. The monitored zone in some wells such as PZ 1, PZ 4, PZ 26, PZ 9S, PZ 9D, PZ 11, PZ 13, and PZ 16D were completely in, while others such as $\mathrm{PZ}$ 8, PZ 12, PZ 15M, PZ 25 and PZ 31 were partially in, Waynesburg Sandstone.

\section{A. Pre-Mining Water Wells}

Under this category, water head monitoring began far ahead of in-panel or the nearest panel mining and the monitoring zone consisted of either completely or partially in the Waynesburg Sandstone.

a. Monitoring Zone completely in Waynesburg Sandstone

\section{PZ 1 in Panel 1}

When Panel 3 was mined, the water head in PZ 1, located approximately $1,000 \mathrm{ft}$ north of the northern edge of Panel 3 , dropped about $5 \mathrm{ft}$ and soon recovered to above the pre-mining level. When Panel 1 was mined, its water head dropped $16 \mathrm{ft}$ and held steady until after Panel 4 was mined. The water head rose about $20 \mathrm{ft}$ before, during and after Panel 5 mining. Thereafter, water head fluctuated throughout the monitoring period reflecting the wet and dry conditions of the weather, not panel mining.

\section{PZ 4 in Panel 4}

When Panel 3 was mined, PZ 4 located about $800 \mathrm{ft}$ south of the southern edge of Panel 3, its water head dropped about $6 \mathrm{ft}$ and rose $5 \mathrm{ft}$ before Panel 1 was mined. Due to lack of data points, it was not sure how did the water head react exactly to Panel 1 , which was at least $1,800 \mathrm{ft}$ north of PZ 4. It appeared that its water head dropped during or soon after

Panel 1 mining. During Panel 4 mining, its water head dropped about $5 \mathrm{ft}$ 
and then rose $18 \mathrm{ft}$ prior to Panel 5 mining. It dropped about $5 \mathrm{ft}$ during Panel 5 mining, but soon recovered to pre-Panel 5 mining level. Thereafter, water head fluctuated throughout the monitoring period reflecting the wet and dry conditions of the weather.

\section{PZ 13 in Panel 7}

Monitoring of PZ 13 began approximately 1 month prior to Panel 7 mining. Its water head dropped quickly about $9 \mathrm{ft}$ during Panel 7 mining and rose more than $40 \mathrm{ft}$. It fluctuated before, during and soon after Panel 8 mining, the northern edge of which was about 1,070 ft south of PZ 13 . Thereafter, water head fluctuated throughout the monitoring period reflecting the wet and dry conditions of the weather, not panel mining.

\section{PZ 16D in Panel 8}

Water head in PZ 16 D was not affected by Panel 8 mining, or by Panel 9 mining. The fluctuation of the hydrograph appeared to reflect the weather and thus recharge condition of the sandstone aquifer.

b. Monitoring zone partially in Waynesburg Sandstone

\section{1. $P Z 12$ in Panel 7}

The monitored zone consisted of a large portion of clay shale at the top and at the bottom, a small section of the top section of the Waynesburg Sandstone aquifer.

Monitoring began about one month before Panel 7 mining. Water head dropped less than $1 \mathrm{ft}$ during Panel 7 mining and recovered to above the pre-mining level quickly. The water head fluctuated slightly throughout subsequent panel mining, i.e., panels 8, 9, and 10.

\section{2. $P Z 15 M$ in Panel 8}


The monitoring zone of $\mathrm{PZ} 15 \mathrm{M}$ was almost identical to that of $\mathrm{PZ}$ 12 except that its bottom portion had a smaller section of the top section of the Waynesburg Sandstone.

Mining of Panel 7, the southern edge of which was about $850 \mathrm{ft}$ north of PZ 15M dropped the water head about $2 \mathrm{ft}$. But when Panel 8 was mined, it had no effect. The adjacent panels 9 and 10 had no effect either.

\section{B. Post-Mining Water Wells}

Under this category, the monitoring zone in some wells consisted completely of Waynesburg Sandstone while others only partially.

a. Monitoring zone completely in Waynesburg Sandstone

\section{PZ 26 in Panel 5}

Monitoring began about 3 months prior to Panel 9 mining. The water head was not affected by Panels 9 mining. It rose and dropped about $15 \mathrm{ft}$ right before and after Panel 10 mining, respectively. Thereafter, it fluctuated until the end of monitoring period.

\section{PZ 9S, PZ 9D and PZ 11 in Panel 6}

The monitoring zones of PZ 9S and 9D were located at the top and bottom of the Waynesburg Sandstone, respectively, and began about one month before Panel 7 mining.

The water head in PZ 9D dropped nearly $10 \mathrm{ft}$ during and soon after Panel 7 mining. But it quickly rose to about $5 \mathrm{ft}$ above the pre-Panel 7 mining level. Panel 8 mining caused about $4 \mathrm{ft}$ of water head drop, Panel 9 had no effect, while Panel 10 caused about $14 \mathrm{ft}$ drop, recovered and then fluctuated.

The water head in PZ 9S dropped and rose similar to 9D except that the magnitude was much smaller. This was reasonable since both 
piezometers were located in the same aquifer, and 9S being shallower, thereby reacting to surface water recharge much quicker.

The hydrograph of PZ 11 was very similar, both in pattern and magnitude, to that of $P Z 9 D$, because their monitoring zones were both located at the bottom of the Waynesburg Sandstone.

b. Monitoring zone partially in Waynesburg Sandstone

\section{1. $\mathrm{PZ} 31$}

PZ 31 was located on a 4-entry gateroad development north of Panel 1 North, the most northern part of this 10-panel section. The monitoring zone consisted of a small section of Waynesburg Sandstone in the upper portion, a large section of silty shale in the middle and a small section of coal in the lower part. Monitoring of water head in PZ 31 began during Panel 8 mining. Water head dropped $12 \mathrm{ft}$ after Panel 8 mining, rose and dropped slightly before and after Panel 9 mining. It then rose to the pre-Panel 8 mining level before Panel 10 mining. After that, it dropped and fluctuated until the end of monitoring period.

\section{2. $P Z 8$ in Panel 4}

The monitored zone consisted of a small section of Waynesburg Sandstone in the upper portion and the remaining part in the lower portion was silty shale. Monitoring of PZ 8 began about one month before Panel 7 mining. The hydrograph of $\mathrm{PZ} 8$, being in the same vicinity, was very similar to that of PZ 4. Although fluctuated, the water head appeared to be independent of all subsequent panel mining, i.e., panels 7, 8, 9, and 10.

\section{PZ 25 in Panel 7}

The monitoring zone of $P Z 25$ was the same as $P Z 12$ except that PZ 25 was slightly higher in elevation. The northern edge of Panel 9 was about 2,500 south of PZ 25. 
The monitoring period was very short, from late July to mid October 2002. During this period only Panel 9 mining was conducted and it had no effect on the water head.

\subsubsection{Waynesburg Limestone}

PZ 32 was the only well with its monitoring zone located in Waynesburg Limestone, which was about 5-6 ft in this area, and mostly likely was not an aquifer. PZ 32, just likes PZ 31, was located in the 4-entry development section north of this panel section.

The monitored zone consisted of about $5 \mathrm{ft}$ Waynesburg limestone in the middle and the remainder was clay shale. Water head monitoring began right after Panel 8 mining which was more than $7,500 \mathrm{ft}$ to the south. Water head dropped $5 \mathrm{ft}$ during, but rose $15 \mathrm{ft}$ after Panel 9 mining. It then dropped $40 \mathrm{ft}$ and rose $57 \mathrm{ft}$ gradually before Panel 10 mining. Thereafter, it fluctuated like many other wells until the end of monitoring period.

\subsubsection{Mannington Sandstone}

Mannington Sandstone was shallow, 70-80 ft deep. It was about $11 \mathrm{ft}$ thick, and located about $410 \mathrm{ft}$ above the Pittsburgh Seam.

There were two water wells in Panel 9 monitoring the water heads in Mannington Sandstone, PZ 20 and PZ 23 in Panel 9.

The monitoring zone of PZ 20 consisted of about $4 \mathrm{ft}$ Mannington Sandstone on the top and $8 \mathrm{ft}$ of clay shale on the bottom. Monitoring of water head began soon after Panel 7 mining. Water head was steady until about one month before Panel 8 mining. It dropped about $35 \mathrm{ft}$ during and soon after Panel 8 mining, and stayed at low level until Panel 9 mining. But right after Panel 9 mining, it rose $60 \mathrm{ft}$ and stayed there. The fluctuation pattern of the water head appeared to be weather-related because the same water drop spanning between May through mid December 2002 occurred in all hydrographs in Waynesburg Sandstone which was about $35 \mathrm{ft}$ below.

The monitoring zone of PZ 23 consisted of $10.5 \mathrm{ft}$ of clay shale on the top and $1.5 \mathrm{ft}$ of Mannington Sandstone on the bottom. The hydrograph shows 
similar trends as that of PZ 20 prior to Panel 8 mining. After Panel 8 mining, it fluctuated but dropped slowly about $5 \mathrm{ft}$. Water head rose during and after Panel 9 mining, followed by a drop of $9 \mathrm{ft}$. It rose before and dropped after Panel 10 mining.

\subsubsection{Waynesburg Coal}

Waynesburg coal was about 1-2 ft thick and 324-396 ft above the Pittsburgh Seam.

There were two water wells monitoring the water heads in Waynesburg Coal, PZ 27 in Panel 5.

The monitoring zone of PZ 27 consisted of $4.5 \mathrm{ft}$ of Waynesburg coal in two splits at the lower section while the remaining section was $7.5 \mathrm{ft}$ of clay shale. Monitoring of water head began several months before Panel 9 mining. Immediate after mining, it rose, although fluctuated, more than $40 \mathrm{ft}$ all the way before Panel 10 mining. Water head dropped after Panel 10 mining and then fluctuated greatly. The fluctuated water head appeared to reflect the weather condition, not mining effect, because many hydrographs showed the same fluctuation.

\subsubsection{Aquitards}

\section{Clay Shale and Silty Sandstone}

\section{PZ 28 in Panel 5}

The monitored zone was completely in clay shale which was $257 \mathrm{ft}$ above the Pittsburgh Seam. Monitoring of water head began about three months before Panel 9 mining. The hydrograph is very similar to that of PZ 27 except fluctuation in smaller magnitude.

\section{PZ 10 in Panel 6}

The monitored zone consisted of $4.5 \mathrm{ft}$ of Calvin Limestone in the lower portion and $7.5 \mathrm{ft}$ of clay shale. The bottom of the monitoring zone was about 400 $\mathrm{ft}$ above the Pittsburg Seam.

Monitoring began several months before Panel 7 mining. Water head rose after all 4 panel mining (i.e., Panels 7, 8, 9 and 10). The trends of the hydrograph 
look very similar to those of PZ 9S, 9D and 11 in Panel 6, especially 9S both in trends and magnitude of change.

\section{PZ 24 in Panel 7}

The monitoring zone of PZ 24 was completely in clay shale which was 443 $\mathrm{ft}$ above the Pittsburgh Seam.

The monitoring period was very short, from late July to mid October 2002, exactly the same as PZ 25 in the same panel. During this period only Panel 9 mining, the northern edge of which was about 2,500 south of PZ 24, was conducted and it had no effect on the water head.

\section{PZ 14S in Panel 8}

The monitoring zone of PZ $14 \mathrm{~S}$ consisted of $1.5 \mathrm{ft}$ of Calvin Limestone on the very top and $2 \mathrm{ft}$ of coal in the middle, and $6.5 \mathrm{ft}$ of clay shale. The bottom of the monitoring zone was $397 \mathrm{ft}$ above the Pittsburgh Seam.

Monitoring began a few weeks before Panel 7 mining which had no effect. Right before and during Panel 8 mining, water head fluctuated but rose to above pre-mining level soon after mining. Mining of Panels 9 and 10 had no effect either.

The trends of the hydrograph look similar to that of PZ 16, also in Panel 8. 5. PZ 17S, 18M, and 19D in Panel 8

The monitoring zones consisted of the following: PZ 17S, completely in silty shale, the bottom of which was $465 \mathrm{ft}$ above the Pittsburgh Seam. PZ 18M, 8 $\mathrm{ft}$ of silty shale on the top and $2 \mathrm{ft}$ of clay shale on the bottom, which was $457 \mathrm{ft}$ above the Pittsburgh Seam. PZ 19D, $3 \mathrm{ft}$ of clay shale on the top and $8 \mathrm{ft}$ of silty shale on the bottom, which was $419 \mathrm{ft}$ above the Pittsburgh Seam.

Monitoring of water head for all three wells began a few weeks before Panel 7 mining. The hydrographs for all three wells exhibit similar trends. Longwall mining did not affect the water heads and the fluctuation of hydrograph reflected the weather condition, notably the large simultaneous drop of water heads for all three wells between May and October 2002.

The trends of all three hydrographs were similar to those of PZ 14 and 15, also in Panel 8. 


\section{PZ 21 in Panel 9}

The monitored zone of PZ 21 consisted of $4 \mathrm{ft}$ shale on the top and $8 \mathrm{ft}$ silty shale on the bottom, which was $570 \mathrm{ft}$ above the Pittsburgh Seam.

Monitoring of water head began right after Panel 7 mining. Both Panel 8 and 9 mining did not affect the water head. In fact, water head rose after mining, especially after Panel 9 mining.

7. PZ 22 in Panel 9

The monitoring zone of PZ 22 consisted of all clay shale except about 1.3 $\mathrm{ft}$ of coal in the middle.

Monitoring of water head began right after Panel 7 mining. Mining of Panel 8 and Panel 10 that were $950 \mathrm{ft}$ and $600 \mathrm{ft}$ away, respectively, did not affect its water head. But in-panel mining of Panel 9 caused about $5 \mathrm{ft}$ drop of water head, which was recovered later.

\subsection{Analysis of Monitored Data}

\subsubsection{Major Aquifer Strata}

\section{Sewickley Sandstone}

Since Sewickley Sandstone was only about $100 \mathrm{ft}$ above the Pittsburgh Seam, it would be completely broken after longwall mining. Therefore water wells in Sewickley Sandstone will be completely lost during in-panel mining and its water head will also be affected by adjacent panel mining.

\section{Uniontown Limestone}

The monitored zone, 228-238 ft above the Pittsburgh seam, was located entirely in the Uniontown limestone, the bottom of which was about 130-140 ft above the Pittsburgh Seam. Therefore, the entire Uniontown Limestone was located within the fractured zone after Panel 1 was mined, though the monitored zone was in the upper portion of the fractured zone. Because the ratio of interburden thickness to mining height $=240 \mathrm{ft} / 7 \mathrm{ft}=34$. Consequently, its water head would drop quickly and considerably during in-panel (Panel 1) mining, but recovered sometimes after mining. It would also be affected by mining in 
adjacent panels due to the uniformity of Uniontown Limestone across all 9 panels. In fact, it was affected nearly by all panels mining, though the magnitude of water head drop decreased when panels were increasing away from it, and the impact became slower. Since the monitored zone was located in the upper portion of the fractured zone, water head would recover soon after mining. Therefore, its hydrograph will fluctuate.

\section{Waynesburg Sandstone}

Waynesburg Sandstone was about 330-360 above the Pittsburgh Seam. So it was in the upper portion of the fractured zone after longwall mining in the Pittsburgh Seam.

There were 8 wells, the monitored zones of which were completely in Waynesburg Sandstone, or 340 - $380 \mathrm{ft}$ above the Pittsburgh Seam. Their hydrographs exhibited similar general trends. Due to difference in location, and time of installation, i.e. either pre- or post-mining, they are grouped into the following groups for convenience of discussion.

PZ 1 in Panel 1 and PZ 4 in Panel 4 were both shallow wells, 20-23 ft deep, with their monitoring zones completely in Waynesburg Sandstone. Monitoring of both wells covered the whole period when this section of 7 panels was being mined. Both wells were about 2,900 ft apart and yet their hydrographs were very similar. Although differing in magnitude, duration and rate de-watering and water recovery, their trends were very similar and the effect extended up to when panel mining was $7,000 \mathrm{ft}$ away, i.e. water head drops and rise slowly (frequently rising to above the pre-mining level) mostly after each panel mining.

PZ 26 in Panel 5, $40 \mathrm{ft}$ deep, and PZ 11, 9S, and 9D in Panel 6, 20-77 ft deep, were all post-mining wells, being installed after Panel 7 mining. PZ 13 in Panel 7, $69 \mathrm{ft}$ deep, was installed about one month before Panel 7 mining. The hydrographs of those five wells exhibit similar trends: Water head was steady or rising before Panel 7 mining. It dropped various degrees during and immediately after Panel 7 mining. It then fluctuated, but quickly rose 15-50 ft above the premining levels before Panel 8 mining. Panel 8 mining caused slight drop of water 
head. After mining it rose and then dropped $17-50 \mathrm{ft}$ for a considerable length of time until after Panel 9 mining. Panel 9 mining had no effect on water head, which rose gradually and then quickly right before Panel 10 mining. After Panel 10 mining, it dropped and fluctuated to various degrees until the end of monitoring period.

PS 16 in Panel 8, $60 \mathrm{ft}$ deep, was installed prior to Panel 7 mining. Panel 7, $800 \mathrm{ft}$ away, and 8 mining had little effect, while Panel 9 mining, $670 \mathrm{ft}$ away, had no effect on its water head. Just like all other 12 wells in Waynesburg Sandstone, Panel 10 mining caused some drop of water head which then fluctuated until the end of monitoring period.

\subsubsection{Aquitards -Clay Shale and Silty shale with Sandstone Streaks}

The monitored zones of the following 9 water wells were located either in clay shale or silty shale: PZ 31 and 32 in the gateroad north of the panel section, PZ 5A and 8 in Panel 4, PZ 27 and 28 in Panel 5, PZ 10 in Panel 6, and PZ 14 and 15 in Panel 8. The depth of monitored zones ranged from 20 to $100 \mathrm{ft}$ with half below $33 \mathrm{ft}$ and half above $40 \mathrm{ft}$. The hydrographs of all 9 wells showed similar trends regardless whether they were installed pre- or post-mining. Take those for PZ 14 and 15 in Panel 8 for example, Panel 8 mining, $800 \mathrm{ft}$ away showed little effect. So was in-panel (Panel 8) mining. After Panel 8 mining, water head dropped but held steady for a period of 4-5 months, ignoring Panel 9 mining. After Panel 9 mining, water head rose continuously and slowly until Panel 10 mining, which caused minor drop of water head. Thereafter, water head fluctuated until the end of monitoring period. Obviously trends are similar to those located in Waynesburg Sandstone.

\subsubsection{Summary}

Among the 31 monitored water wells, two wells, PZ 24 and PZ 25, were only monitored for two and half months, and one well, PZ 12, showed no response throughout the monitoring period of nearly three years. The behavior of the remaining 28 water wells can be summarized as follows: 
There were two wells, PZ 3 and PZ 6, located in the Sewickley Sandstone that was 107-117 ft above the Pittsburgh Seam and thus became highly fractured after mining. Therefore both adjacent panel (Panel 3) and in-panel (Panel 1) caused the water head continued to drop a total of more than $85 \mathrm{ft}$. Water head not only recovered but rose to about $30 \mathrm{ft}$ above the pre-mining level. Thereafter, the water head fluctuated throughout the monitoring period just as all other wells in Waynesburg Sandstone. The reason that the water head recovered was mostly likely due to the water fed from thicker Sewickley Sandstone to the north that was not undermined. The water head in PZ 6, on the other hand, was completely lost after in-panel (Panel 4) mining due to lack of feeding water. Because Sewickley Sandstone to the north had been broken and could no longer keep the water inside. Note water head continued to during Panel 1 mining that was 2,000 ft to the north. Similarly, the water head in PZ 3 dropped $40 \mathrm{ft}$ during and after Panel 4 mining that was 2,200 $\mathrm{ft}$ to the south. This indicated that water wells located in an aquifer will be affected by multiple panel mining depending on location above the coal and the characteristics of the aquifer.

There were also two water wells, PZ 2 and PZ 5, located on the very top portion of the Uniontown Limestone that was 100-110 ft thick and 136-143 ft above the Pittsburgh Seam. So the Uniontown Limestone would also be in the fractured zone after mining. But since the monitored zones were 230-241 ft above the Pittsburgh Seam, its fractured density would be smaller. Since the limestone was so thick and uniformly distributed throughout the 9-panel section, its effect would more severe and wide spread. For example, in-panel (Panel1)

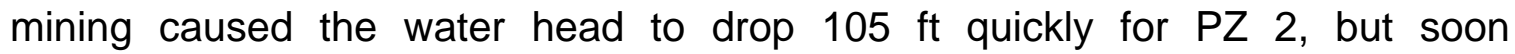
recovered. This drop and rise of water head repeated during and after each subsequent panel mining until after Panel 6 that was about 4,600 ft to the south.

The hydrographs of a total of 18 water wells behaved similarly including 10 water wells (PZ 1, 4, 8, 9S, 9D, 11, 13, 15, 26, and 31) in Waynesburg Sandstone, 1 each in Waynesburg Limestone, Waynesburg Coal, and Mannington Sandstone, and 5 in clay shale or silty shale. These hydrographs feature a much high water head during Panel 6, 8 and 10 mining and much lower 
water head during Panel 7 and 9 mining. Panel mining had no or minor effect on their water heads. Water heads quickly rose to above pre-mining level if they were dropped during panel mining. This trends of high and low water heads corresponded to those of precipitation stated in the next section. Therefore, the long-term hydrographs reflected more of weather condition, rather than longwall mining below. For those cases where water heads exhibited short-term temporary drop, it may be due to the fact that Waynesburg Sandstone was located at the very top portion of the fractured zone generated by longwall mining below, or weather recharge condition on the surface, or both. If it was due completely to longwall mining, it was temporary and would recover totally.

The hydrographs of the remaining 7 water wells (PZ 16, 17, 18, and 19 in Panel 8, and PZ 20, 21 and 22 in Panel 9) located in clay or silty shale show somewhat different trends during their monitoring period. These hydrograph feature a low water head between Panel 8 and Panel 10 mining for deep wells (PZ 16, 20 and 22) and fairly steady water heads for shallow wells (PZ 17, 18, 19 and 21). However panel mining did not affect their water heads in all cases except PZ 20 in Panel 9 during Panel 8 mining. 


\subsection{Precipitation and Stream flow Monitoring}

Precipitation data for the Waynesburg area, which was used to generate Appendix 2:, was collected from 12/1/2001 to 6/2/2004. This set of data was obtained from the visitor center on I-79 near Kirby, PA (I-79 Welcome Center, 2007). In Appendix 2:, Stream flow monitoring data for Stations SW 24, 25, 33, 34, and 37 were plotted along with the precipitation data for comparison. Noticed there were obvious trends: there were considerable precipitation between April 1 and July 5, 2002 during which longwall mining was in Panel 8; Between June 15 and October 12, 2002 it was a period of low precipitation and mining was conducted from Panel 8 to 9; Between October 30, 2002 and February 28, 2003, there were occasional high and/or consistent low precipitation and mining was conducted between Panel 9 and 10; and after May 10, 2003 , there were plenty of precipitation. This was post-Panel 10 mining period.

The high flow periods for stream flow monitoring stations appeared to coincide with those of high precipitation. For instance, 3/10/01-4/5/01, 4/30/01-5/30/01, 12/30/021/5/03, 2/20/03-3/30/03, 5/3/03-6/10/03, 8/27/03-10/2/03, 11/2/03-2/18/04, and 3/24/04$4 / 27 / 04$.

\subsection{Effect of Longwall Mining on Surface Stream}

\subsubsection{Stream flow Analysis of Selected Surface Monitoring Stations}

In order to assess the effect of longwall mining on surface stream flow, the difference of measured stream flow between two monitoring stations were compared before and after mining.

\subsubsection{Comparison of Stream Flow between Stations M7 and SW37}

Station M7 was located over the gateroad between Panels 6 and 7 (See Figure 3). Station SW37 was located in Panel 8. Station M7 was in the downstream from SW37 and their surface elevations were at 1,045 and 1,055 ft, respectively. Therefore, the watershed for M7 was larger than that for SW37 and consequently, water flow at M7 should be larger than that at SW37 at the same time before mining or if mining does not 
affect the stream flow. Based on this assumption, the flow rate difference between M7 and SW37 can be used to estimate the effect of mining on stream water. Panel 7, located between these two monitoring stations, and was mined from September 26th, 2001 to February 10th, 2002. Since there were no data collected at Station M7 prior to Panel 7 mining, only the flow rate differences between M7 and SW37 during and after Panel 7 mining are shown in Table 1.

Table 1 Comparison of Flow Rates Between M7 and SW37

\begin{tabular}{l|c|c|c|c|c}
\hline \multicolumn{5}{c}{ Difference in Flow Rate } \\
\hline \multicolumn{3}{c}{$\begin{array}{c}\text { During mining } \\
\text { (gpm) }\end{array}$} \\
\multicolumn{4}{c}{$\begin{array}{c}\text { After mining (gpm) } \\
(9 / 7 / 01 \sim 2 / 8 / 02)\end{array}$} \\
\hline Ave & Max & Min & Ave & Max & Min \\
\hline-42 & 15.1 & -230 & 26.2 & 255.1 & -143.5 \\
\hline
\end{tabular}

** note a negative value means the flow rate at M7 was less that that of SW37 while a positive value means the flow rate at M7 was larger than that of SW37.

Table 1 shows that the flow rate at M7 was less than that of SW37 during the mining in Panel 7. The flow rate difference (M7 - SW37), on average, was $-42 \mathrm{gpm}$. About two years later, in first half of 2004, the flow rate at M7 was more than that of SW37, i.e., the flow rate difference (M7 SW37), on average, was $26.2 \mathrm{gpm}$. Therefore, it appears that there was some water loss during Panel 7 mining, located between M7 and SW37.

\subsubsection{Comparison of Stream Flow between Stations SW37 and SW24}

Station SW24 was located over Panel 6 and Station SW37 was over Panel 8 as shown in Figure 49. Station SW24 was in the downstream from SW37 and their surface elevations were at 1,025 and 1,055 ft, respectively. The watershed for SW24 was larger than that for SW37 and consequently the flow rate at SW24 should be larger than that 
at SW37 at the same time prior to mining and if mining has no effect on them. Two longwall panels, i.e., Panels 6 and 7, were located between these two monitoring stations. Mining of these two panels could change the flow rate difference between the two stations if there were effects of longwall mining on surface stream water. So the flow rate difference between SW24 and SW37 can be used to estimate the effects of longwall mining. Panel 6 was mined from April 21st, 2001 to September 16th, 2001 and Panel 7 was mined from September 26th, 2001 to February 10th, 2002. The monitoring data in Table 2 shows that the flow rate difference between SW24 and SW37 before, during, and after mining Panels 6 and 7.

From Table 2, it can be seen that the flow rate of SW24, on average, was larger than that of SW37 before mining with the flow rate difference (SW24 - SW37), on average, being $151.6 \mathrm{gpm}$. However, the flow rate of SW24, on average, was less than that of SW37 during mining and the flow rate difference (SW24 - SW37) becomes negative, - $42 \mathrm{gpm}$, on average. Similarly, about two years later, the flow rate difference, on average, was $276.9 \mathrm{gpm}$, i.e. the flow rate at SW24 was larger than that of SW37 after mining. Stream flow was lost sometimes during mining, but recovered completely after two years.

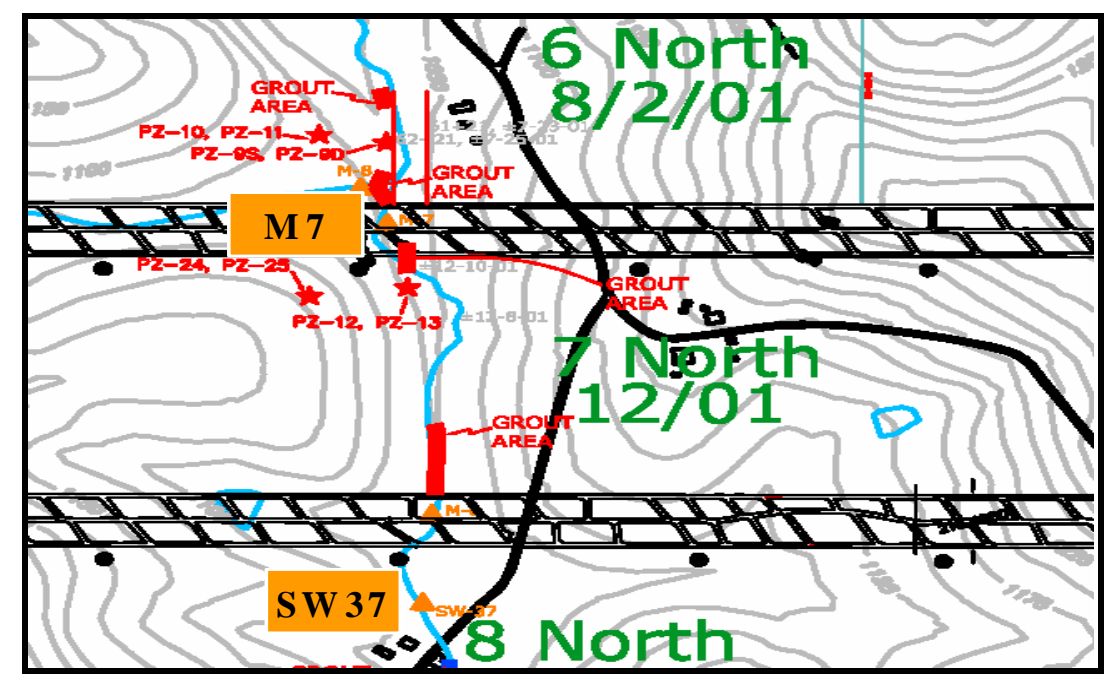

Figure 48 Location of station M7 and SW37 


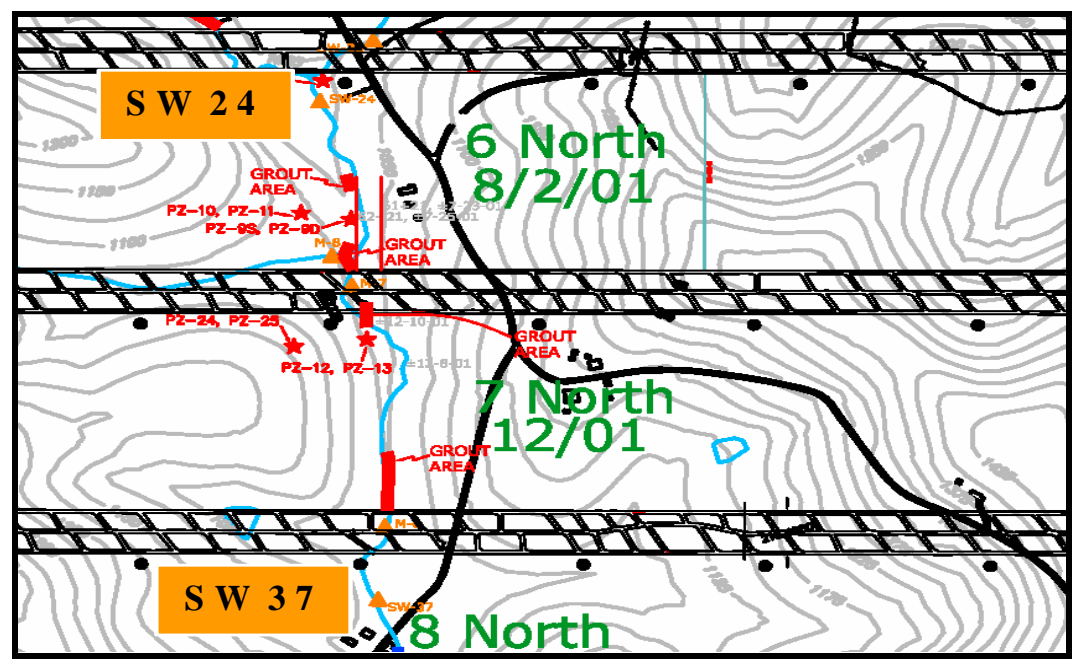

Figure 49 Location of station SW24 and SW37

Table 2 Flow Rate Difference

\begin{tabular}{ccccccccc}
\hline \multicolumn{8}{c}{ Flow Rate Difference } \\
\hline \multicolumn{3}{c}{ Before mining } & \multicolumn{3}{c}{ During mining } & \multicolumn{3}{c}{ After mining } \\
$(4 / 24 / 98 \sim 7 / 21 / 01)$ & \multicolumn{2}{c}{$(8 / 2 / 01 \sim 2 / 8 / 02)$} & \multicolumn{2}{c}{$(1 / 27 / 04 \sim 6 / 2 / 2004)$} \\
\hline Ave & Max & Min & Ave & Max & Min & Ave & Max & Min \\
151.6 & 773 & -39 & -42 & 0 & - & 276.9 & 1244 & 33
\end{tabular}

** note a negative value means the flow rate at M24 was less that that of SW37 while a positive value means the flow rate at M24 was larger than that of SW37. 


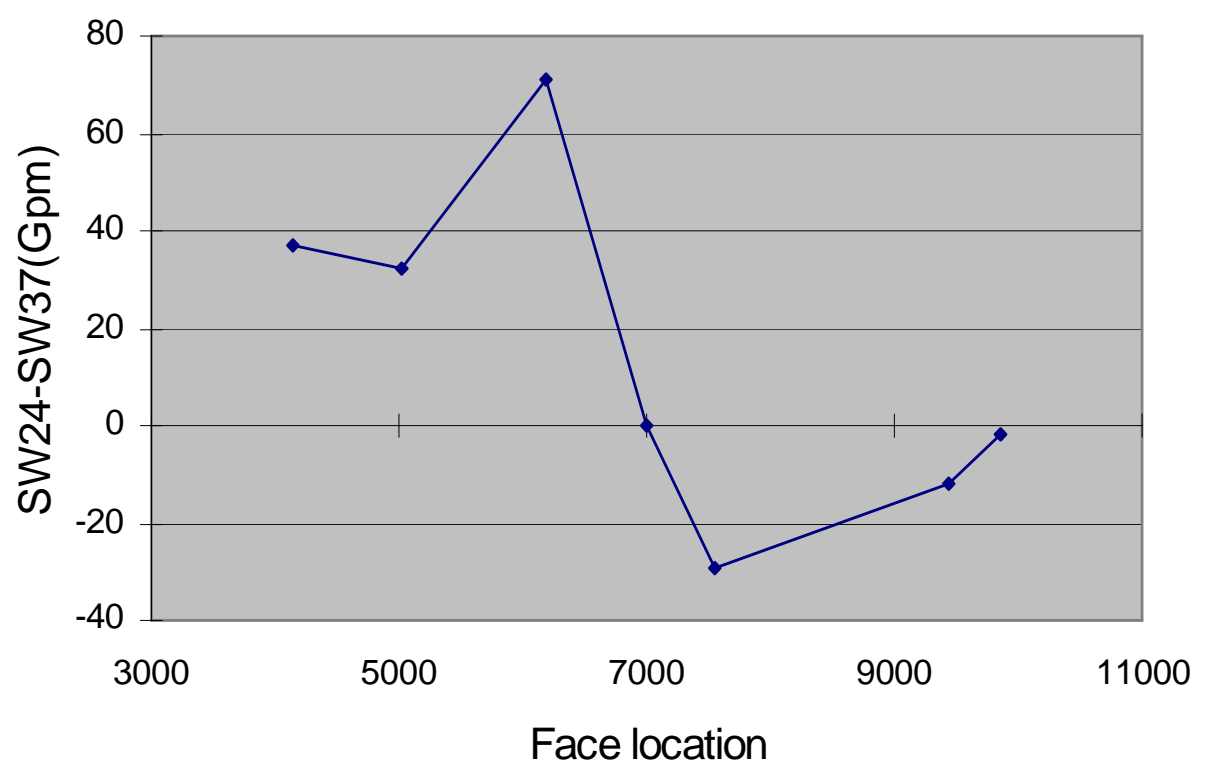

Figure 50 Water flow difference when mining Panel 6

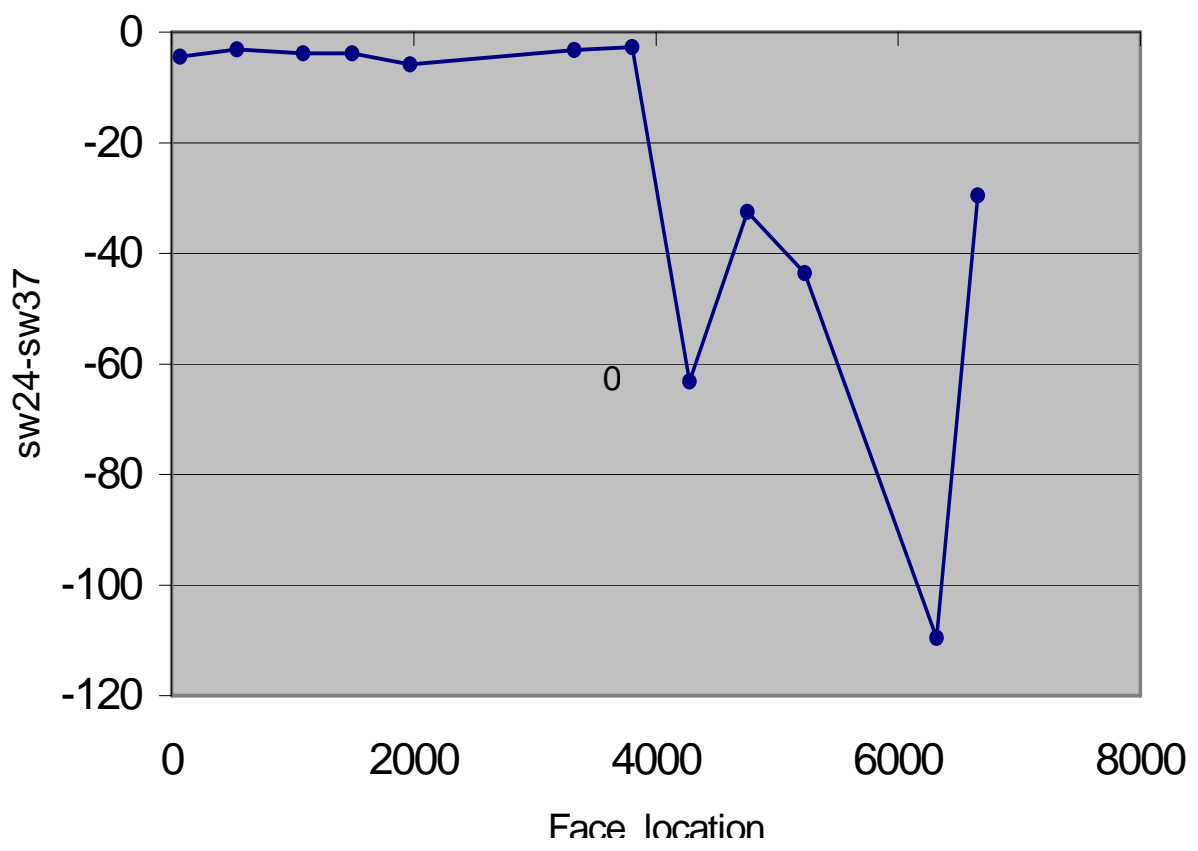

Figure 51 Water flow difference when mining Panel 7

During the mining of Panel 6 , after the face passed through the stream (about 7,000 $\mathrm{ft}$ from the setup entry), the flow rate difference (SW24 - SW37) becomes negative (Figure 50). During mining of Panel 7 , after the face passed through the stream (about 5,000 ft from the setup entry), the flow rate difference decreased dramatically (Figure 51). 
Therefore, the effect of longwall mining on stream water flow was visible.

\subsubsection{Comparison of Stream flow Between Stations M5 and M4 and M4A}

Station M5 was located on the gateroad near the southern edge of Panel 8. Stations M4 and M4A, monitoring different small tributaries of the stream, were both located on Panel 9 (Figure 52). M5 was downstream and M4 and M4A were upstream with surface elevations at 1,065, 1,075 and $1,070 \mathrm{ft}$, respectively. These three stations were located close to each other and the flow rate at M5 should be equal to or slightly more than the sum of M4 and M4A before mining or if mining would not affect them. During mining of Panel 8, Station M5 could be affected, while M4 and M4A should not be affected. Conversely, during mining of Panel 9, Stations M4 and M4A could be affected, while M5 should not be affected. Therefore, the water flow rate difference $[M 5-(M 4+M 5)]$ could be changed if mining do affect surface stream water. So the flow rate difference between M5 and M4+M4A can be used to estimate the effect of mining on stream water. Panel 8 was mined from February 13th, 2002 to June 24th, 2002, while Panel 9 was mined from July 4th, 2002 to December 4th, 2002.

The flow rate monitoring data of these three stations are shown in Table 1.3 in the forms of difference between M5 and (M4+M4A) before, during, and after mining of Panels 8 and 9. It shows that the flow rate of $M 5$, on average, was larger than the sum of (M4+M4A) before mining and the flow rate difference, on average, was $79.3 \mathrm{gpm}$. However, during mining of Panel 8 (when the face was at about 7,000 ft from the setup entry), the maximum flow rate difference was $-263 \mathrm{gpm}$ (Figure 53). In other words, the flow rate of M5 was less than that prior to the Panel 8 face passed through the stream. During mining of Panel 9, after the face passed through the stream (at about 6,500 ft from the setup entry), the flow rate difference became negative (Figure 54), or on average, -2.5 gpm, i.e., the flow rate of M5 was less than that of (M4+M4A). Slightly 
more than one year after mining in 2004, the flow rate difference, on average, was $88.5 \mathrm{gpm}$, which was slightly more than the value before mining, i.e., the flow rate of M5 was larger than the sum of M4 and M4A. Therefore, some water was lost during mining of Panels 8 and 9, but recovered completely one year later.

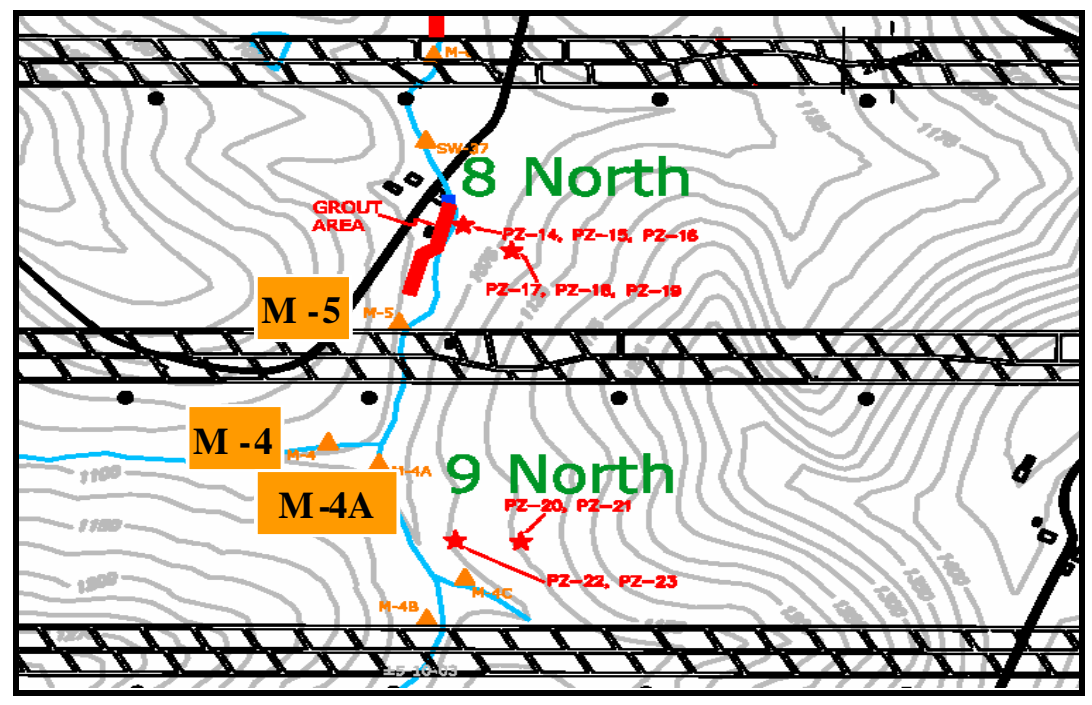

Figure 52 Location of station M5, M4 and M4A

Table 3 Comparison of Flow Rate between Stations M5 and M4+M4A

\begin{tabular}{|c|c|c|c|c|c|c|c|c|}
\hline \multicolumn{9}{|c|}{ Flow Rate Difference } \\
\hline \multicolumn{3}{|c|}{$\begin{array}{c}\text { Before mining } \\
(10 / 30 / 01 \sim 5 / 24 / 02)\end{array}$} & \multicolumn{3}{|c|}{$\begin{array}{l}\text { During Panel } 8 \text { mining } \\
\text { During Panel } 9 \text { mining }\end{array}$} & \multicolumn{3}{|c|}{$\begin{array}{c}\text { After mining } \\
(1 / 12 / 04 \sim 6 / 2 / 2004)\end{array}$} \\
\hline Ave & Max & Min & Ave & $\operatorname{Max}$ & Min & Ave & $\operatorname{Max}$ & Min \\
\hline \multirow[b]{2}{*}{79.3} & \multirow[b]{2}{*}{322} & \multirow[b]{2}{*}{-17} & & -263 & & \multirow[b]{2}{*}{88.5} & \multirow[b]{2}{*}{361.8} & \multirow[b]{2}{*}{7.5} \\
\hline & & & -2.5 & 1.3 & -9.1 & & & \\
\hline
\end{tabular}




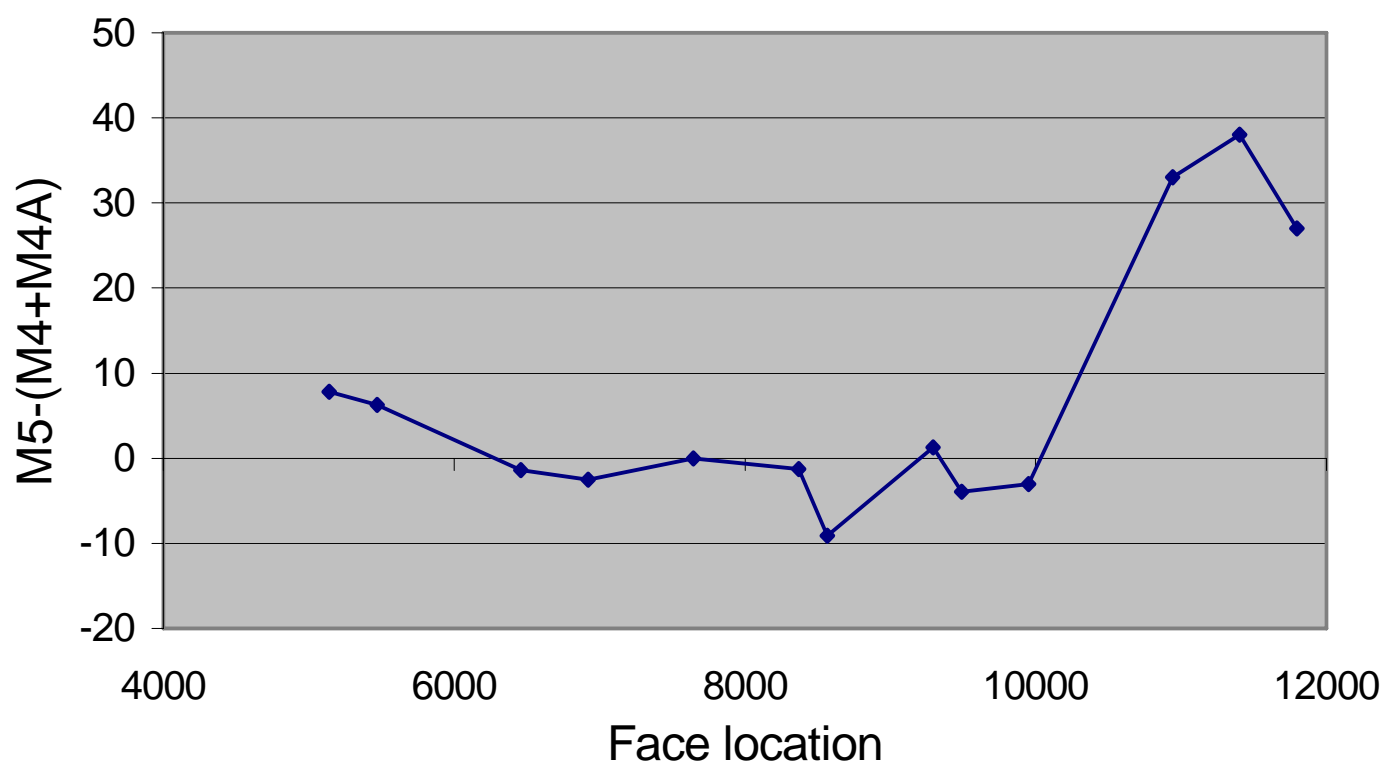

Figure 53 Water flow difference when mining Panel 8

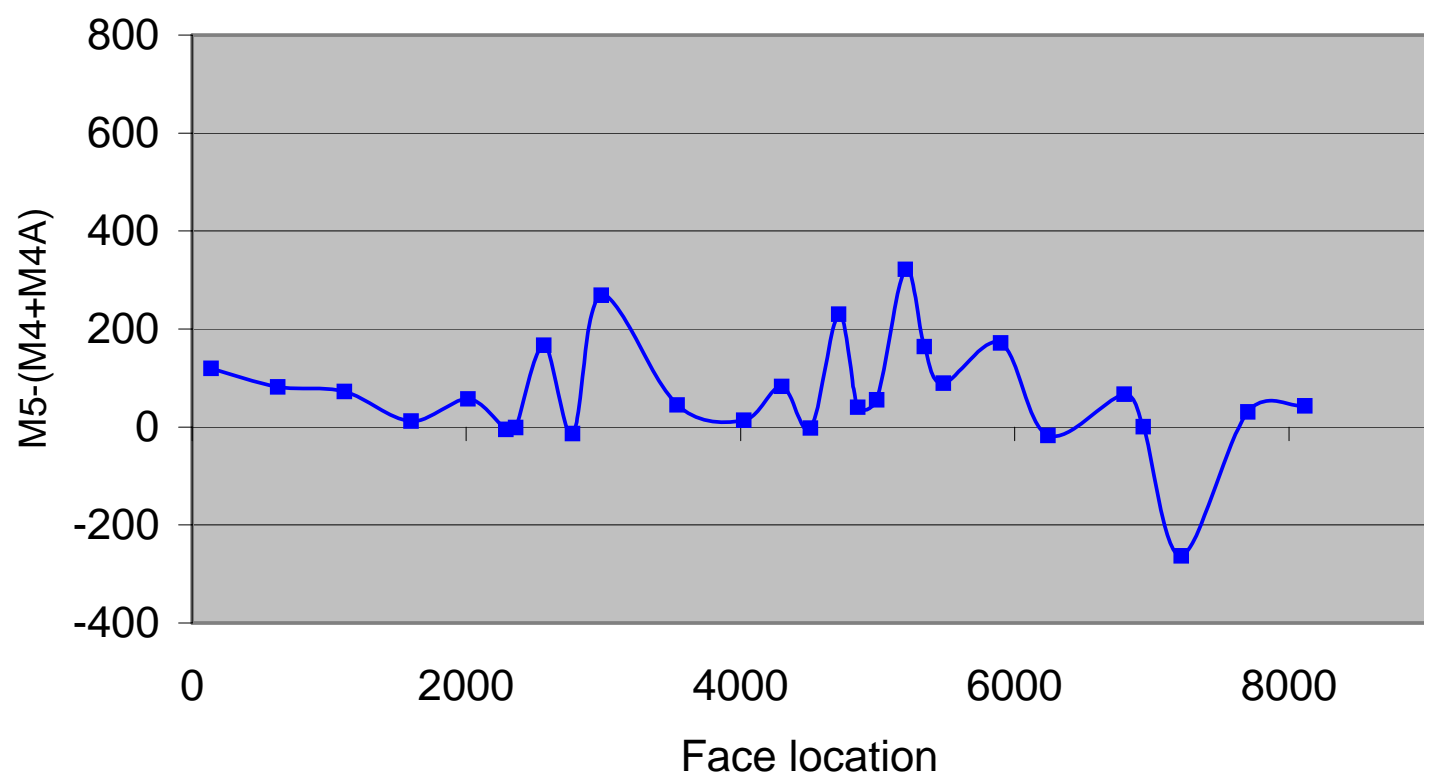

Figure 54 flow difference when mining Panel 9

Based on the above analysis of monitoring data in three sites, it can be concluded that the stream flow could have been affected by longwall mining after the longwall face had undermined the stream for a period of time or distance. But the effect of longwall mining on stream water is temporary because it will 


\subsubsection{Mechanisms of De-watering due to Longwall Mining}

After a longwall panel is extracted, the surface above is subject to the compressive and tensile strains. Some minor surface cracks would appear in tensile areas when the tensile stress exceeds the critical value of the soils (or rock). Cracks can be formed on the surface and subsurface. Generally speaking, the surface cracks, into which the surface water can flow more easily, may be generated on and near the two edges of panel. Sometimes surface cracks in front of the face can appear because of the dynamic surface subsidence. Even though no visible surface cracks are generated in the tensile areas, the permeability of the soils or rocks in those areas increased due to the tensile strain.

When the surface stream water encounters these surface cracks or tensile areas with increased permeability, it enters the cracks and stay there. So the downstream water would decrease or become dry. That is the reason why the difference between two water-monitoring stations becomes smaller during longwall mining. When the surface cracks are more abundant or sufficiently deep, and the surface water is low because of weather conditions, the surface stream would become dry.

\subsubsection{Summary}

Based on the data analysis and comparisons of stream flows between the monitoring stations, the following conclusions can be made:

1. Longwall mining has some effects on the surface stream water after the face has passed the stream for a period of time. Stream water could be lost completely or decrease due to longwall mining. The lost water is stored in the loosened soil zone or expanded rock layers in the tension zones near the surface resulting in a lowered water table, but not unlikely deep in the underground mined voids.

2. The effect of longwall mining on stream water is temporary. It takes some time for the lowered water table to be recharged by the surface stream and rain falls. In this studied case, about one or two years later, surface stream 
water recovered completely.

3. The effects of longwall mining on stream water can be attributed to two aspects: one is that the stream water enters the surface cracks. 


\section{Chapter 5 Conclusions}

Analysis was conducted for the hydrologic data monitored from February 1998 through June 2004 for the Laurel Run including 30 water wells, 8 surface stream flow stations, and precipitation. The conclusions drawn from the analysis are:

1. All water wells, except those located on the hill sides and hill tops, the bottom of which was more than $400 \mathrm{ft}$ above the Pittsburgh Seam, were temporarily affected by longwall mining below. Specifically,

a) Sewickley Sandstone, 2-20 ft thick, Uniontown Limestone, 100-122 ft thick, and Waynesburg Sandstone 10-57 ft thick, in ascending order, were the three major aquifer strata. Since they were 107-117 ft, 230-255 ft, and 330-355 ft above the Pittsburgh Seam, respectively, they were located in the fractured zone created due to longwall mining below. The severity of strata fractures decreases in ascending order and the effect of longwall mining was also in that order. Sewickley Sandstone was in the highly fractured zone while Uniontown Limestone was in the medium-fractured zone. The water heads of water wells in these zones dropped almost instantaneously and in very large magnitude. But they recovered sometime after mining. Water wells in Waynesburg Sandstone dropped slightly and slowly. They also recovered sometime later.

b) Water wells in the same aquifer stratum were affected by multiple panel mining up to nearly a mile away. The magnitude of effect decreased as the distance increased.

c) Water wells in the clay and silty shale, up to $90 \mathrm{ft}$ deep, were not affected by longwall mining below.

d) Nearly all water wells regardless of depth, except those located on the hill sides and hill tops in Panels 8 and 9, were affected by the dry and wet seasons of weather and fluctuated accordingly.

e) Water wells located on hill tops and hill sides in Panels 8 and 9 and more than $400 \mathrm{ft}$ above the Pittsburgh Seam were not affected by longwall mining. Their hydrographs were steadier, not fluctuated like others corresponding to weather conditions. 
2. Stream flow was affected by longwall mining, but recovered within 1-2 years after mining. 
A. E. Becher, The Geology of Pennsylvania Chapter 44: Groundwater, 1999. Pennsylvania Geological Society, Lancaster, PA, pp670.

L. Mays, D. Todd, Groundwater Hydrology. 2005. New Jersey, Wiley and Sons. 36-37 Pennsylvania DEP Bureau of Watershed Management, "Groundwater Monitoring Guidance Manual", December 2001. pp1

The Pennsylvania State Climatologist. I-79 Exit 002 Welcome Center, PA Precipitation Data 2001-2004. 2007.

S. S. Peng, H. S. Cheng. Longwall Mining. 1984. New York, Wiley and Sons. pp708.

S. S. Peng. Coal Mine Ground Control. Second Addition, 1986. New York, John Wiley and Sons. 
Appendix 1:

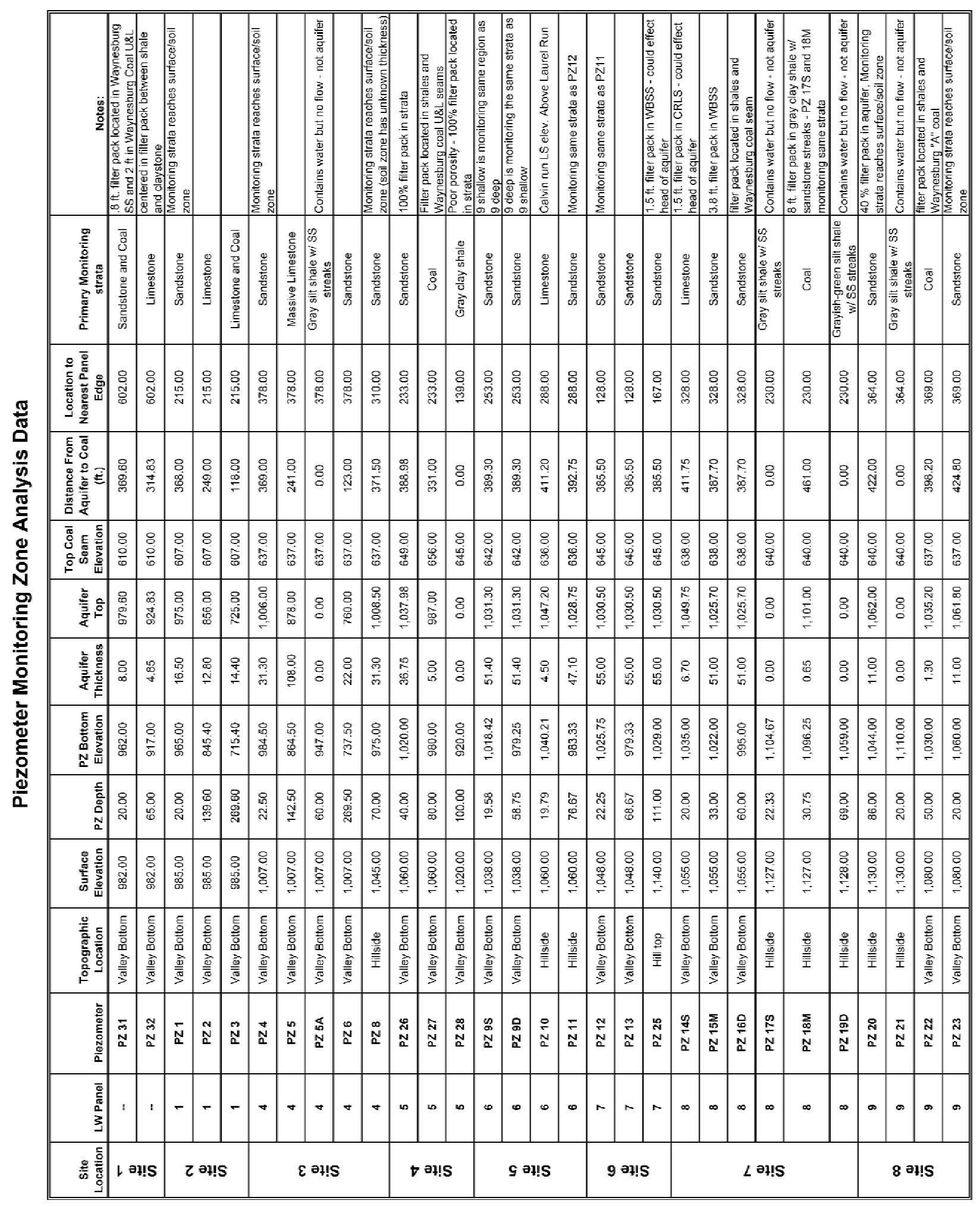




\section{Appendix 2:}

\section{Laurel Run Stream Flow and Precipitation Comparison}

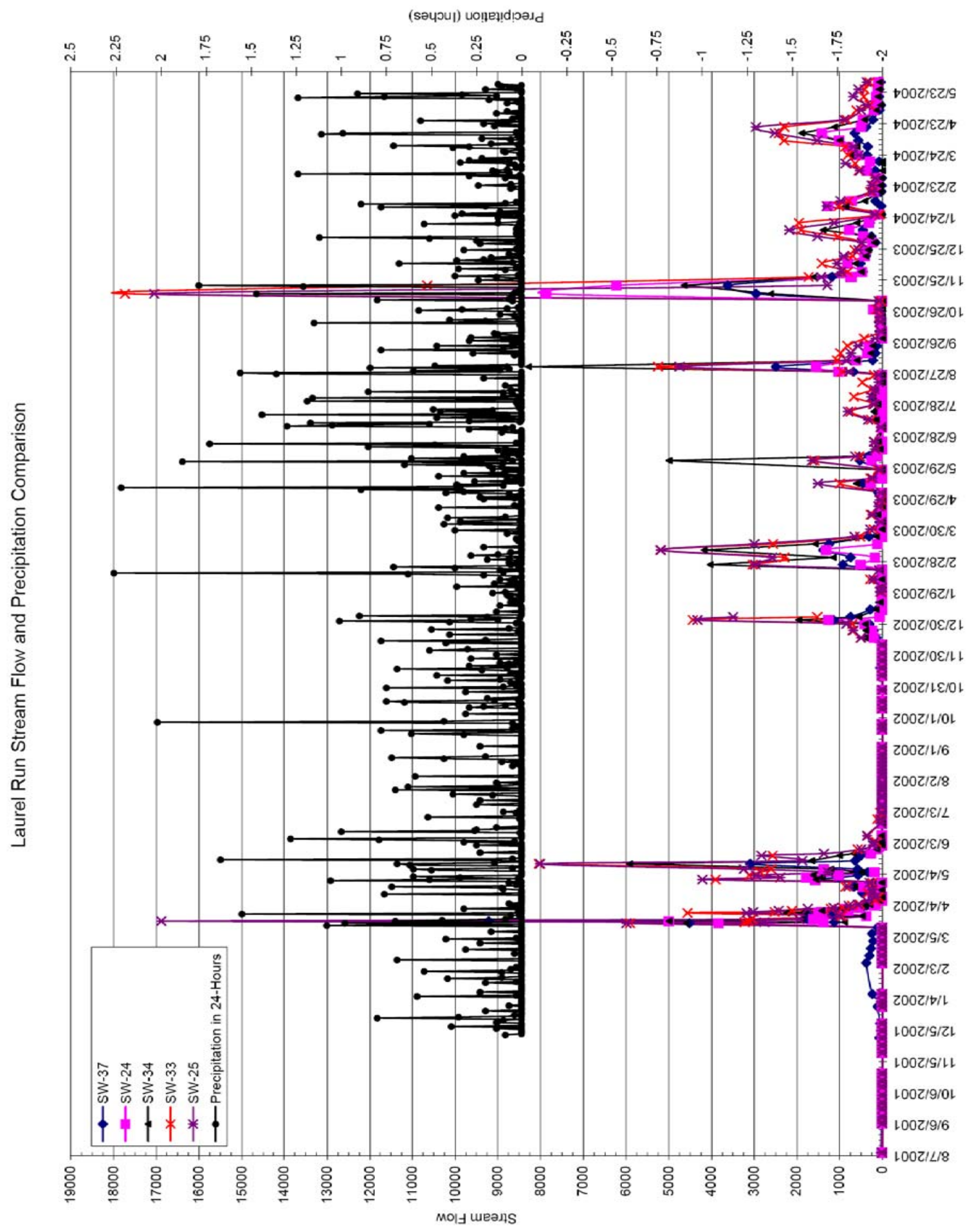




\section{Vit a}

\section{Joseph R. Zirkle}

jzirkle@mix.wvu.edu

\section{Education}

\section{Masters of Science in Mining Engineering}

West Virginia University, Morgantown, WV 26506.

Anticipated Graduation: May 2007; Current GPA 4.0

Advisor: Dr. Syd. S. Peng

\section{Bachelor of Science in Mining Engineering}

West Virginia University, Morgantown, WV 26506.

December 2004; GPA 3.14

\section{Master's Thesis}

"Analysis of Water Monitoring Data for Longwall Panels"

Project Goals:

1. Analyze the affects of longwall induced subsidence on surface and subsurface water systems using hydrographs.

2. Compare the subsidence affects on the aquifers to the source of recharge or precipitation.

3. Determine which aquifers/aquitards were permanently and temporarily affected by mining.

\section{Job Experience}

1. Staff Engineer

MEPCO, Inc. Morgantown, WV

September 2006 to present: Mine Permitting, Planning and Design.

2. Engineering Internship

Consol Energy: McElroy Mine, Moundsville, WV

Summer 2006: 4 Months Underground Surveying and Surface Site Design Conveyor Belt and Slope Construction Sites.

3. Engineering Internship

Consol Energy: Robinson Run Mine, Mannington, WV

Summer 2001 to Summer 2005 